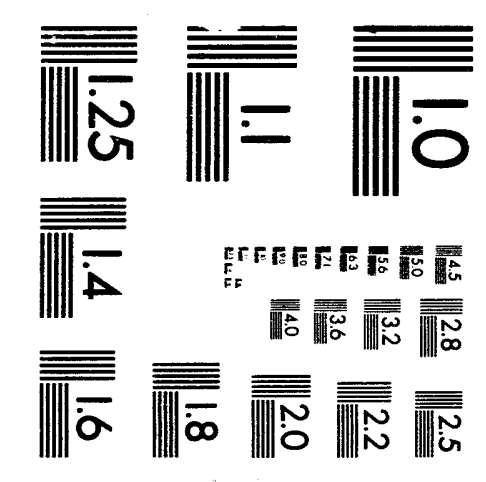



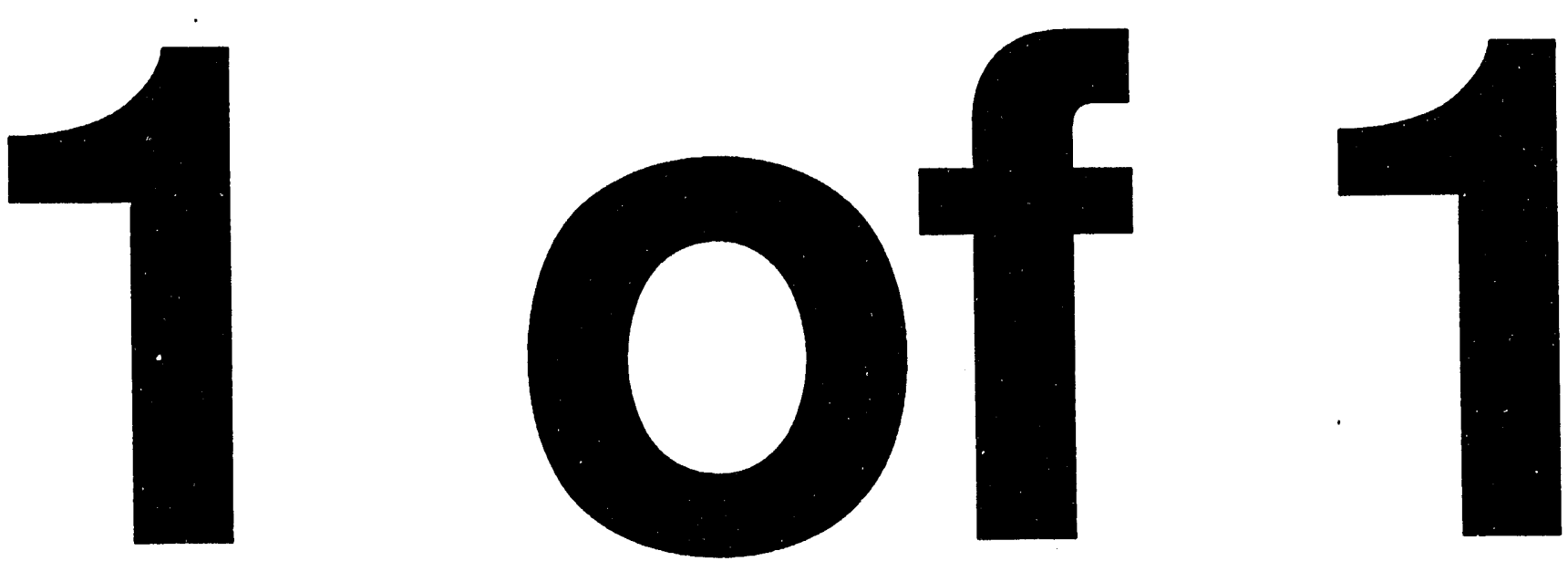


\title{
Technical Requirements for the Actinide Source-Term Waste Test Program
}

\author{
Mark L. F. Phillips and Martin A. Molecke \\ Sandia National Laboratories \\ Albuquerque, NM 87185
}

\begin{abstract}
This document defines the technical requirements for a test program designed to measure time-dependent concentrations of actinide elements from contact-handled transuranic $(\mathrm{CH}$ TRU) waste immersed in brines similar to those found in the underground workings of the Waste Isolation Pilot Plant (WIPP). This test program will determine the influences of TRU waste constituents on the concentrations of dissolved and suspended actinides relevant to the performance of the WIPP. These influences (which include $\mathrm{pH}$, Eh, complexing agents, sorbent phases, and colloidal particles) can affect solubilities and colloidal mobilization of actinides. The test concept involves fully inundating several TRU waste types with simulated WIPP brines in sealed containers and monitoring the concentrations of actinide species in the leachate as a function of time. The results from this program will be used to test numeric models of actinide concentrations derived from laboratory studies. The model is required for WIPP performance assessment with respect to the Environmental Protection Agency's 40 CFR Part $191 B$.
\end{abstract}

\section{MASTER}




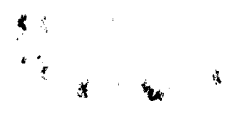




\section{CONTENTS}

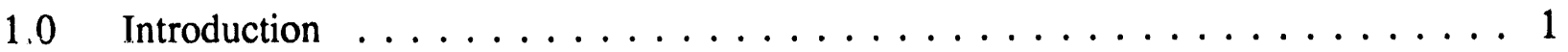

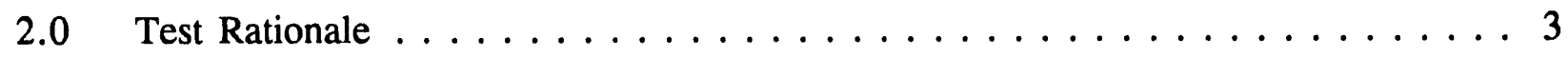

2.1 Influences on Actinide Mobility $\ldots \ldots \ldots \ldots \ldots$

2.2 Relationship to Laboratorv Program . . . . . . . . . . . . . . . 9

2.3 Conditions of the Disposal Rooms . . . . . . . . . . . . . . 11

2.4 Conditions of the Test Containers $\ldots \ldots \ldots \ldots \ldots$

2.4.1 Test Compromises . . . . . . . . . . . . . . . 15

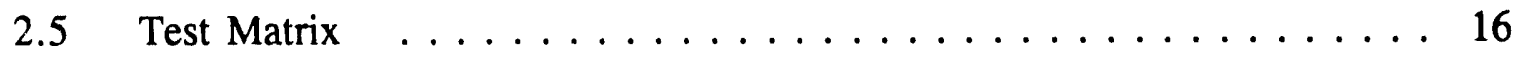

2.6 Analytical Requirements .................... 20

2.6 .1 Leachate Sampling . . . . . . . . . . . . . . . . . . 20

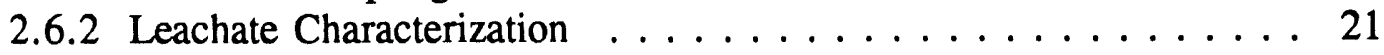

2.6 .3 Gas Measurement ..................... 24

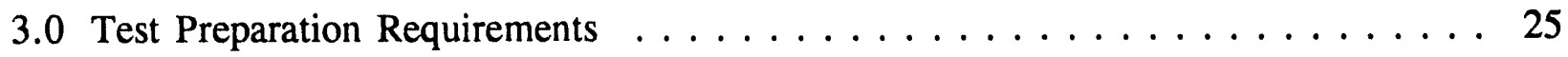

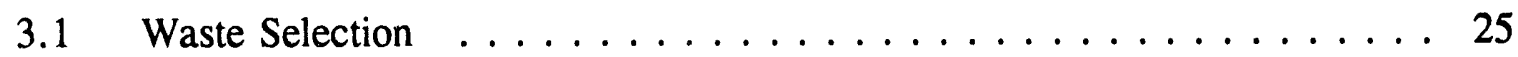

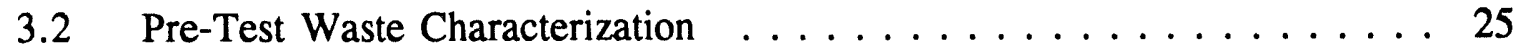

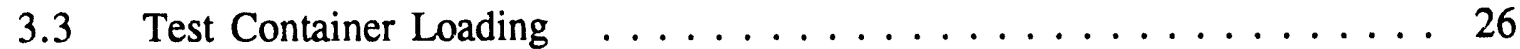

3.4 Design Requirements ..................... 28

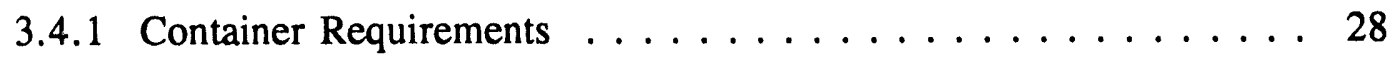

3.4.2 Mixing and Sampling Requirements . . . . . . . . . . . . . . . 29

3.4.3 Temperature Monitoring and Control . . . . . . . . . . . . 30

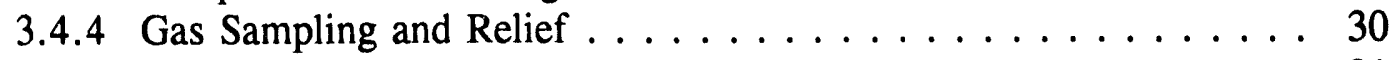

3.4 .5 Leak-Tightness . . . . . . . . . . . . . . . . . 31

3.4.6 High-Pressure Experiments ............... 32

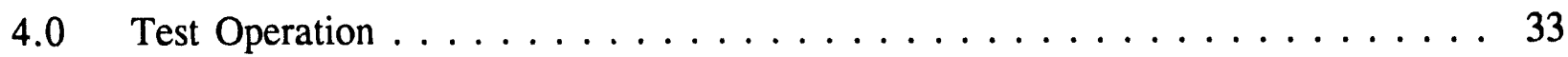

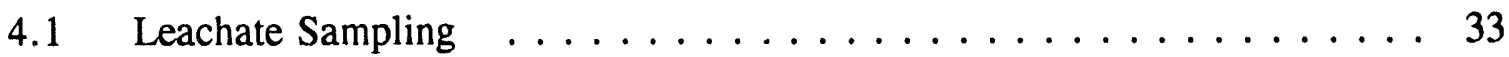

4.2 Leachate Analysis . . . . . . . . . . . . . . . . . . 33

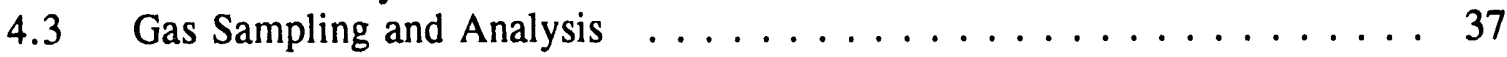

4.4 Other Operational Considerations $\ldots \ldots \ldots \ldots \ldots \ldots$

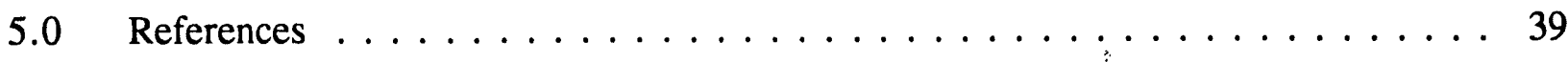




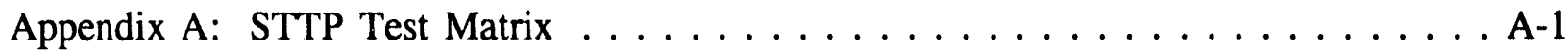

Appendix B: Effect of Increased $\mathrm{CO}_{2}$ Pressure on Brine Chemistry $\ldots \ldots \ldots \ldots$ B-1

Appendix C: Procedure for Preparing Inoculated Brine $\ldots \ldots \ldots \ldots \ldots \ldots$ C-1

Appendix D: Release versus Solubility Scatterplots $\ldots \ldots \ldots \ldots \ldots \ldots \ldots$ D-1

Appendix E: Cement Leaching $\ldots \ldots \ldots \ldots \ldots \ldots \ldots \ldots \ldots \ldots \ldots \ldots \ldots$

Appendix F: Brine-Backfill Ratio $\ldots \ldots \ldots \ldots \ldots \ldots \ldots \ldots \ldots \ldots \ldots$ F-1

Appendix G: Steel Additive $\ldots \ldots \ldots \ldots \ldots \ldots \ldots \ldots \ldots \ldots$ G-1

\section{Figures}

1 Oxidation potential (Eh) vs. $\mathrm{pH}$ phase diagram for $\mathrm{Pu}$ in $\mathrm{H}_{2} \mathrm{O}$ at $298 \mathrm{~K} \ldots \ldots 6$

2 Possible excursions and eventual conditions of disposal rooms in Eh/pH space . . . 7

3a Ranges of normalized releases for various actinide isotopes at $t=1000$ years in an E1E2 (double borehole) intrusion scenario $\ldots \ldots \ldots \ldots 22$

3b Plots of normalized release vs. solubility for Th (IV), U (IV), Np (V), $\mathrm{Pu}$ (IV), and Am (III) in an E1E2 (double borehole intrusion) scenario with no retardation in the Culebra at $\mathrm{t}=1000$ years $\ldots \ldots \ldots \ldots 23$ 


\subsection{INTRODUCTION}

This document defines the technical rationale and requirements for a test program designed to determine the concentrations of actinides in WIPP brines in contact with transuranic (TRU) wastes. This study is referred to as the Actinide Source-Term Waste Test Program (STTP). The long-term Waste Isolation Pilot Plant (WIPP) performance assessment program requires estimates of the concentrations of plutonium and other radionuclides in disposal rooms that may become partially or completely filled with brine. Once mobilized, these radionuclides may be released to the accessible environment under certain circumstances such as human intrusion into the repository. Actinide source-term data are thus necessary for determining compliance of the repository with Environmental Protection Agency (EPA) 40 CFR 191B (Marietta et al., 1989).

The STTP will complement laboratory studies of radionuclide chemistry. The Actinide Source-Term laboratory program has previously determined solubilities and sorption coefficients of plutonium and its oxidation state analogs in synthetic brines under various conditions of $\mathrm{pH}$ and has examined actinide speciation and measured stability constants for complex ions (Brush, 1990). In addition, the program has measured distribution coefficients for actinides in brines in the presence of suspended bentonite. The current focus of the laboratory program includes chemical equilibrium modeling for dissolution and investigations of colloid stability and kinetics.

The results from these laboratory experiments will allow the development of a predictive numeric model of concentrations of mobile actinides in brine as a function of chemical conditions within the disposal rooms. The principal role of the STTP will be to test the utility of the predictive model by examining the degree to which actinides are mobilized in real TRU waste under repository realistic conditions. The goals of both the laboratory and real waste source-term test programs are to develop and evaluate a radionuclide source-term model that will provide a narrower uncertainty range of actinide concentration data to WIPP performance assessment than is currently available from expert judgments using existing data.

In brief, the test concept involves filling test containers with a variety of actual contact-handled $(\mathrm{CH})$ TRU wastes and completely saturating the containers with a mixture of natural and synthetic brines with compositions chemically similar to those of intergranular brines found in the Salado Formation. Container size will depend on waste homogeneity; heterogeneous waste types such as combustibles will use "drum scale" vessels of approximately $250 \mathrm{~L}$ volume, while more homogeneous types such as sludges will use "liter scale" test containers of 2-5 $\mathrm{L}$ volume. The containers will permit regular sampling of brine and headspace gas. The wastes will be intentionally fortified or "spiked" with actinides to a level that will ensure that concentration measurements will reflect equilibrium conditions and will not be limited by the quantity of actinide in the waste sample. In addition, certain wastes will be spiked with waste constituents that are expected to increase solubility, such as 
complexing agents, to measure the sensitivity of actinide concentration to these matrix components. The test vessels will also be inoculated with halophilic and halotolerant microbes found in the WIPP underground and on the surface nea: the WIPP Site. This may identify effects of microbial activity on the mobilization of actinides. Prior to test initiation, the containers will be purged of oxygen to simulate the environment predicted for the WIPP disposal rooms after they have been filled and sealed.

During operation the test environment will be held at constant temperature, again to simulate the conditions of the post-closure WIPP disposal rooms. The test containers will be agitated to promote thorough mixing of the solids with the brine and to keep brine compositions homogeneous. Brine samples will be withdrawn at regular intervals throughout the experiment. The leachate samples will be analyzed to ascertain the chemical and physical form and concentration of actinides dissolved or dispersed in the brine. These experiments are expected to operate for approximately $2-3$ years, although individual tests may run longer if trends in the measured actinide concentrations so warrant.

This document describes the rationale for the STTP and uses this rationale to develop and justify a set of test requirements; it specifically excludes discussion of detailed testing procedures. The requirements described in this document will be used to develop specific experimental requirements and procedures included in a separate Test Plan. This Test Plan will be written by Los Alamos National Laboratory (LANL), the facility chosen to perform these tests. It should be noted that information generated from the laboratory program, the modeling program or the STTP may require reconsidering one or more of the requirements stated in this document. Any changes in test requirements will be discussed with both LANL and the Department of Energy (DOE) WIPP Project Integration Office. If new or changed requirements result in no significant impacts in budget or schedule, they will be documentec and implemented. LANL and Sandia National Laboratories (SNL) will discuss any changes causing significant budget or schedule impact with the WIPP Project Integration Office Change Control Board prior to implementation. 


\subsection{TEST RATIONALE}

The WIPP performance assessment must evaluate compliance of the WIPP with 40 CFR $191 B$ from the end of the operational phase of the facility through the following 10,000 years. This regulation limits the amount of radioactivity that may be unintentionally released into the accessible environment during the post-closure phase. US EPA (1985) defines allowable releases over 10,000 years, normalized as a function of TRU inventory. The WIPP performance assessment is requited to consider the possibility of inadvertent human intrusion into the repository, and EPA 40 CFR $191 B$ permits the assumption that the intrusion rate does not exceed 30 boreholes $/\left(\mathrm{km}^{2} \cdot 10000 \mathrm{y}\right.$ ) (WPD, 1991b). Future performance assessment estimates of intrusion rate may be time dependent and possibly less than this maximum rate. The probability of accidental release of radioactivity equal to the release limit must not exceed 0.10 , and the probability of a release of up to 10 times the release limit must not exceed 0.001 .

There are three possible mechanisms of radionuclide release: direct release of solids by drilling intrusion, release of volatile radionuclides (e.g., ${ }^{14} \mathrm{C},{ }^{85} \mathrm{Kr},{ }^{222} \mathrm{Rn}$ ), and release through mobilization in local groundwaters. Release of solids can occur through borehole erosion and transport of cuttings and drilling muds to the surface and includes all particulates suspended in brine that are neither dissolved nor considered colloidal. These mechanisms will not be considered in the source-term program, though they dominate some parts of release in the human intrision event. Volatile radionuclides are expected to be a minor component of release, as the only volatile isotope present in significant quantity in a TRU repository will be ${ }^{222} \mathrm{Rn}$. Due to its short half-life the inventory of this isotope will be quite low, and due to its low solubility in brine its impact on the source-term will be negligible.

The Actinide Source-Term Program (modeling, laboratory studies, and real-waste tests) considers radionuclide release through mobilization in groundwaters. Release of radionuclides by groundwater transport is possible due to the presence of brine in the Salado Formation, which surrounds the WIPP disposal rooms. Recent performance assessment calculations (WPD, 1991a) indicate this brine can be released into the accessible environment through human intrusion. If this occurs, contaminated Salado brine can enter the Culebra member of the Rustler Formation, which overlies the Salado and contains mobile groundwater. This contaminated Culebra water could be brought to the surface through wells used for watering livestock or for irrigation. Total release will depend on the concentration of radionuclides in Salado brines, the degree to which they can be dissolved or suspended in Culebra brines, the physical and chemical retardation they experience in the Culebra, and the activity of the cuttings brought directly to the surface.

Salado brine can enter the disposal rooms at a rate that depends on the permeability of the surrounding rock and the pressure inside the disposal rooms. Brine from reservoirs in the Castile can also fill the disposal rooms if intrusions through the WIPP penetrate into the Castile. In the most severe intrusion event, the double-borehole (E1E2) scenario, brine from the Castile is released into the rooms, travels through a portion of the repository, and is 
released to the Culebra via a second borehole. This scenario maximizes the interaction of brine with the waste, and in such an event the amount of radioactivity brought to the Culebra will strongly depend on the quantity of the principal radioactive elements in the WIPP inventory that can be dissolved or colloidally suspended in Salado brine.

The concentration of a particular radionuclide in brine within the disposal rooms will be limited either by the amount present in the disposal rooms or by its maximum possible concentration in brine. The radioisotopes of interest in a release scenario are those present in TRU waste and their daughters. Some of these decay products (e.g., ${ }^{226} \mathrm{Ra}$ ) will be present in such small quantity that their release will be controlled by inventory alone; i.e., it can be assumed that all of the radioisotope dissolves. For the eight actinide isotopes that dominate the radioactivity of TRU waste, however, release will be controlled by the degree to which they can be dissolved or suspended. These isotopes are ${ }^{239} \mathrm{Pu},{ }^{241} \mathrm{Am},{ }^{238} \mathrm{Pu},{ }^{240} \mathrm{Pu}$, ${ }^{237} \mathrm{~Np},{ }^{234} \mathrm{U},{ }^{233} \mathrm{U}$, and ${ }^{230} \mathrm{Th}^{*}$ (Helton et al., 1992). At early times, the bulk of the activity comes from $\mathrm{Pu}\left({ }^{238} \mathrm{Pu}\right.$ and $\left.{ }^{239} \mathrm{Pu}\right)$ and ${ }^{241} \mathrm{Am}$. However, other actinide isotopes come into play during the 10,000 year post-operational phase. The inventories of ${ }^{234} \mathrm{U}$ and ${ }^{230} \mathrm{Th}$ increase as ${ }^{238} \mathrm{Pu}$ decays (99.95\% conversion to ${ }^{234} \mathrm{U}$ after 1000 years), and significant quantities of ${ }^{237} \mathrm{~Np}$ result from alpha-decay of ${ }^{241} \mathrm{Am}$ (ca. $75 \%$ complete after 1000 years). Therefore, to ascertain compliance with 40 CFR $191 \mathrm{~B}$, WIPP performance assessment requires estimates of the concentrations of Th, U, Np, Pu, and Am in Salado brine in contact with TRU waste under disposal room conditions.

It is not possible to predict a single value for the concentration of a given actinide in the disposal rooms. This is principally due to the variety of chemical conditions that can exist within the rooms and the fact that these conditions can vary with time and from room to room. However, such predictive power is not required because 40 CFR $191 B$ is a probabilistic rather than deterministic standard. Instead, a cumulative distribution function is defined for the range of possible concentrations of a particular actinide. Such a function assigns probabilities that the concentration of the actinide will be found below a certain value. This has previously been done by an expert panel elicitation using published values for actinide solubilities, which do not currently include data for brines. Using this process, the estimated concentration range of a cumulative distribution for an actinide depends on the

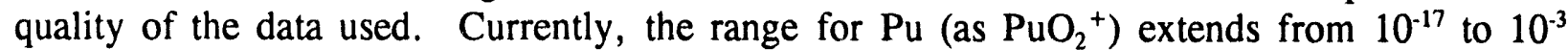
$\mathrm{M}$, or 14 orders of magnitude. The range for $\mathrm{Am}$ (as $\mathrm{AmCl}_{2}{ }^{+}$) extends from $10^{-14}$ to $1 \mathrm{M}$ (Trauth et al., 1991). The upper concentration values and their probabilities are the parameters of greatest concern to Performance Assessment.

The test criteria in this document reflect the intent of the program to analyze the effects of various waste constituents on actinide concentrations in brines. Three independent

\footnotetext{
"The decay series that produce the non-TRU elements is: ${ }^{238} \mathrm{Pu} \rightarrow{ }^{234} \mathrm{U}, \alpha \rightarrow{ }^{230} \mathrm{Th}, \alpha$ and ${ }^{241} \mathrm{Am} \rightarrow$ ${ }^{237} \mathrm{~Np}, \alpha \rightarrow{ }^{233} \mathrm{~Pa}, \alpha \rightarrow{ }^{233} \mathrm{U}, \beta$.
} 
processes are cumulatively responsible for the quantity of actinides that can be supported $\mathrm{i}_{\text {i. }}$ the aqueous phase. These processes are dissolution/precipitation, sorption/desorption and colloid formation/destruction reactions. The test matrix is designed to identify influences or factors within the wastes that can participate in or influence these reactions. To adequately test a chemical model of the dispocal room based on data obtained in the laboratory, it will be necessary to sample test conditions that represent all major influences on actinide mobilization. Given a matrix of reasonable scope and a finite test duration, it may not be possible to access all chemical environments that can be tested in the laboratory. However, this is not essential to testing a laboratory data-based model, which is the principal goal of the source-term test program.

\subsection{Influences on Actinide Mobility}

Disposal room characteristics that may influence actinide mobility include:

1. pH. Particularly high or low hydrogen ion activities may increase actinide solubilities by stabilizing cationic or anionic species in solution. $\mathrm{pH}$ may also affect actinide concentrations by altering the properties of sorbing or complexing agents present in the waste. For example, the complexing or chelating agents expected in the waste matrix are generally more effective at higher $\mathrm{pH}$ values. This is because ligands containing acidic functional groups (e.g., ethylenediaminetetraacetic acid [EDTA], citric acid) will be in their basic or anionic form under these conditions, enhancing their affinities for metal ions. It should be noted that the STTP will measure hydrogen ion concentration $(\mathrm{pcH})$ rather than activity $(\mathrm{pH})$ due to difficulties in measuring $\mathrm{pH}$ in brines.

2. Eh (oxidation potential). Changes in solution Eh (e.g., through radiolysis, anoxic corrosion, microbiological activity, etc.) may increase plutonium solubility relative to that of the very insoluble (IV) oxidation state by oxidizing or reducing the actinide to the more soluble (VI) or (III) states, respectively. The Eh-pH (or Pourbaix) diagram in Figure 1 shows the principal species of Pu produced by hydrolysis, and the conditions under which these species are stable. Active metals in the native state, such as $\mathrm{Al}$ or $\mathrm{Fe}$, may reduce $\mathrm{Pu}$ to the more soluble (III) state. Alpha-radiolysis can produce highly oxidizing species in brines such as hypochlorite ion. Because the $\mathrm{H}_{2}$ gas that is also produced is largely inert, the effect of alpha-radiolysis is to render brines more oxic. This can increase the system Eh and possibly oxidize early actinides to the more soluble (VI) state. This effect may be countered by oxic corrosion of steel. Figure 2 shows how various regions of Eh-pH space may be reached depending on the chemical processes dominant in the waste at a given location and time. Measurements of Eh in complex aqueous systems such as the brine leachates that will be studied in the STTP are difficult to interpret and depend on the electrochemical couple whose potential electromagnetic force (EMF) is being measured. This is due to variations in kinetic barriers among reduction oxidation (redox) equilibria, which are manifested as differences between "true" (thermodynamically reversible) and measured EMFs. The 


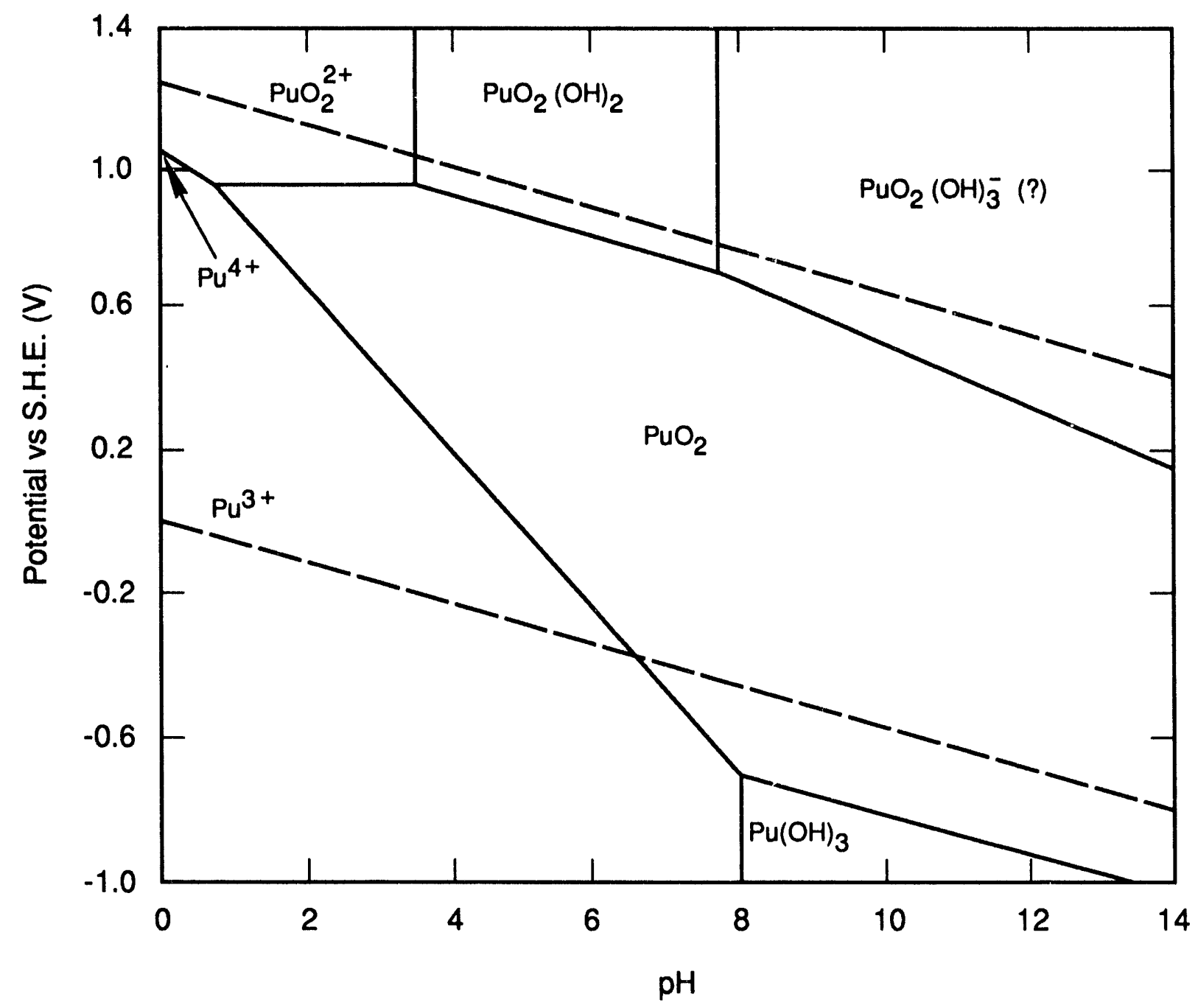

TRI-6345-50-0

Figure 1. Oxidation potential (Eh) vs. $\mathrm{pH}$ phase diagram for $\mathrm{Pu}$ in $\mathrm{H}_{2} \mathrm{O}$ at $298 \mathrm{~K}$ (Baes and Mesmer, 1976, in turn from data of Silver, 1971). Dashed upper and lower lines represent equilibrium with 1 atm $\mathrm{O}_{2}$ and $\mathrm{H}_{2}$, respectively, and thus the stability limits of water under ambient conditions. Note that brine may affect $\mathrm{PL}$ speciation, and that $\mathrm{Pu}(\mathrm{V})$, which is unstable with respect to disproportionation in water at high concentrations, may be present in significant quantity at low Pu concentrations. 


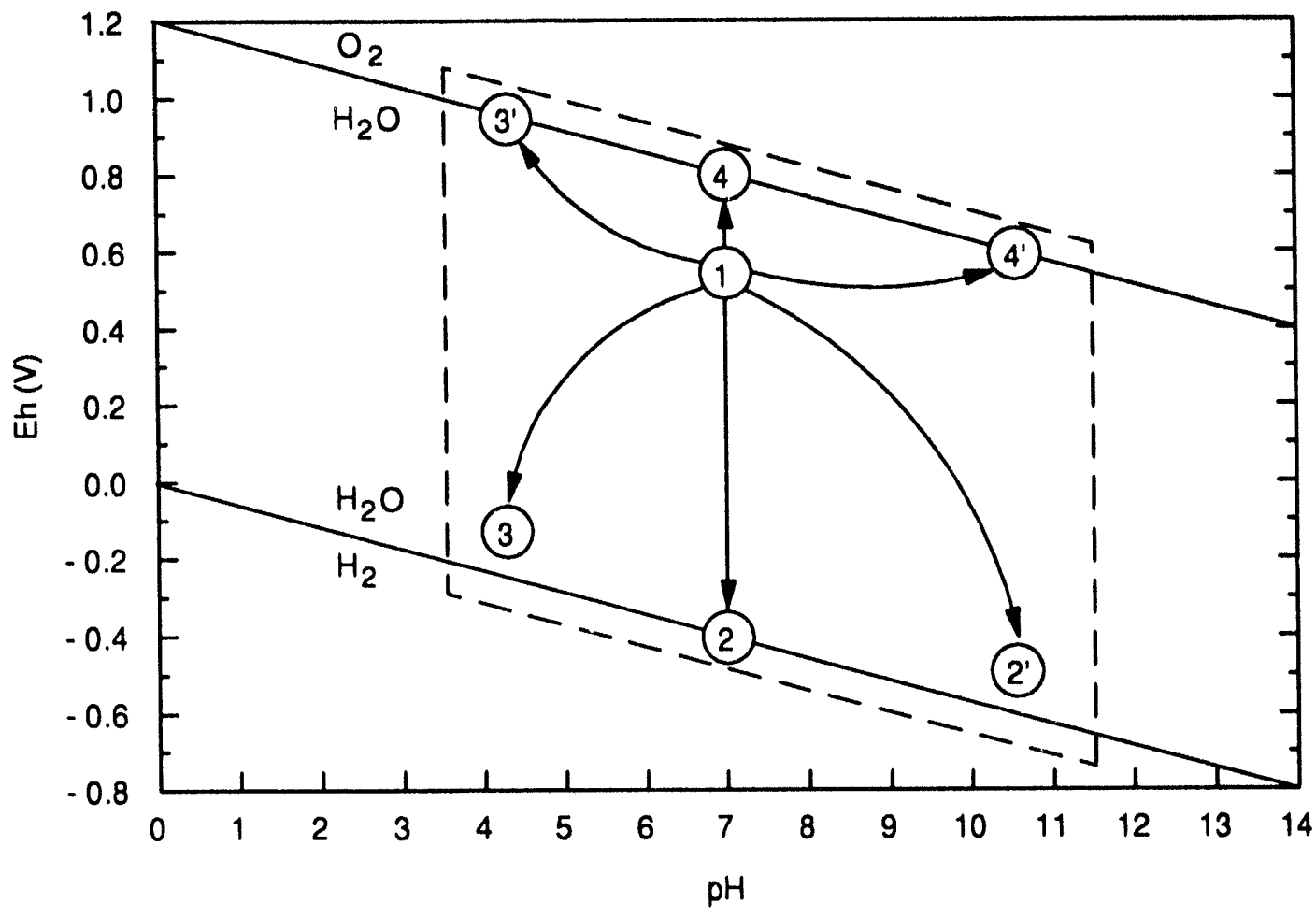

1. Start

3. Microbial Activity

4. Radiolysis

2. Anoxic Corrosion

3'. Microbial Activity, Radiolysis

4'. Radiolysis, Grout

2. Anoxic Corrosion, Grout

TRII-6348-1.0

Figure 2. Possible excursions and eventual conditions of disposal rooms in Eh/pH space. Figure courtesy of L.H. Brush. 
measure of Eh most relevant here is $\mathrm{Pu}$ speciation, but determining $\mathrm{Pu}$ oxidation states in brines is difficult.

3. The presence of complexing agents. Large quantities of complexing and chelating agents (such as EDTA) could increase the amount of actinides in the liquid phase. If significant microbial activity occurs in the waste-brine system, chelating agents may also be produced by the biodegradation of organic material, e.g., $\alpha$-hydroxy carboxylic acids such as lactic and citric acid (Caldwell et al., 1988). A list of chelating and complexing agents that may significantly influence actinide concentrations in aqueous systems and are assumed to be present in TRU waste based upon process knowledge is given in Section 2.4. Carbonate may actually be the most important ligand in the disposal rooms (aside from aquo or hydroxyl ligands resulting from hydrolysis) if it is present in high concentrations in intergranular brines, or if significant quantities of $\mathrm{CO}_{2}$ are generated by microbial activity. A high $\mathrm{CO}_{2}$ fugacity reduces $\mathrm{pH}$ and affects actinide speciation in solution an well as the composition of actinide-containing solid phases (e.g., forming carbonates from hydroxides). These effects have the potential of either increasing or decreasing solubility.

4. The presence of sorbents. Sorption of actinides occurs when dissolved, positively charged actinide ions become bound to negatively charged surface sites on solids such as clays. The sorbed actinide ions will equilibrate with solution phase ions in much the same way that solid phase actinide oxides or salts equilibrate with dissolved actinides. Sorption will tend to reduce solution phase actinide concentrations, assuming that no actinidecontaining solids (other than the sorbents) are present. Sorption will tend to be less efficient under conditions favoring higher actinide concentrations. Sorptive capacity will also vary with $\mathrm{pH}$ and concentrations of other ions in the brines (such as $\mathrm{Al}$ are $\mathrm{Fe}$ ) that can compete with actinide ions for surface sites.

5. The formation of colloidal suspensions. Mobile colloids may adsorb actinides by providing surface sites on which actinide species may be sorbed. These colloidal host particulates (termed carrier colloids or pseudocolloids) may be generated from native clays, backfills, sorbents packed in the waste containers, and from corrosion of iron. The term "colloid" is taken here to include polynuclear actinide species formed by condensation, in which colloidal actinide oxide hydrates (eigencolloids) may result from arrested precipitation of hydrous oxides, particularly $\mathrm{PuO}_{2} \bullet \mathrm{nH}_{2} \mathrm{O}$ (Ockenden and Welch, 1956).

These factors form a five-dimensional parameter space that ideally defines a unique value of actinide concentration for a given set of assumptions about disposal room conditions. The range of possible actinide concentrations in the WIPP disposal rooms is thus determined by the range of conditions accessible within the parameter space. Ultimately, the concentration of each actinide should have a unique value at a given set of conditions once the disposal rooms reach chemical equilibrium. It is not possible to guarantee, however, that the waste-brine system will reach true equilibrium within the life of the STTP experiments or even over the 10,000 year post-disposal period. The test matrix attempts to account for certain perturbations to equilibrium such as high levels of radiolysis (which transiently 
increase Eh) and the chemical state of actinides in the waste (which can either increase or decrease apparent solubility) by providing experimental controls that either isolate the perturbation or cause the system to reach a steady state within the duration of the STTP. These controls are discussed in greater detail in Section 2.5.

\subsection{Relation ship to Laboratory Program}

The actinide source-term laboratory program provides data that will be used to develop a numeric model of actinide sc lubility and suspension in the Salado that accounts for the effects of various chemical influences present in the sealed disposal rooms. These influences include those that affect act nide speciation ( $\mathrm{pH}$, Eh, complexation), as well as sorption and colloid formation. With laboratory data it is possible, in principle, to arrive at a source-term model that ailows calculation of the concentration of an actinide at any selected point in parameter space.

The actinide source-term model may consist of components for dissolution, sorption, complexation, and colloidal suspension. A numeric model for the solubilities of actinides in brine is being developed concurrently with the STTP. This model is based on the Pitzer activity model (see Pitzer, 1991) for concentrated saline systems and has been successful in predicting actinide solubilities in brines (Felmy et al., 1989; Roy et al., 1992). The equilibrium component of the Actinide Source-Term Model will describe solubilities of actinide-containing solid phases and the effects of complexing agents, both inorganic and organic, on these solubilities. Another component of the model will describe the formation and persistence of colloids. Several computer codes that use the Pitzer activity model are available, such as EQ3/6 (Wolery, 1979) and PHRQPITZ (Plummer et al., 1988). The data bases associated with these codes are not sufficient to model actinides in brines, but the necessary mathematics are included. The primary need in this area is data with which to parameterize the model, not model development. The mathematical form that a description of colloids will require is less clear and remains to be elucidated from laboratory data. It is unlikely that modules for calculating the influence of colloids on actinide concentrations will be added to existing codes.

Chemical equilibrium has not been assumed for the formation and persistence of colloids. Concentrations of colloidal forms of minerals, organics, and actinide (principally $\mathrm{Pu}$ ) compounds will be measured in laboratory studies and the STTP. The stabilities of these colloids will also be measured for the expected ranges of ionic strength, $\mathrm{pH}$, and other chemical variables in the pertinent waste-brine-rock systems. Chemical equilibrium has been assumed for adsorption of actinides onto mineral and organic colloids.

The principal objective of the STTP is to test the predictive utility of a numeric model using concentration data obtained from real TRU wastes subjected to conditions anticipated in the disposal rooms. The STTP is thus designed to complement the laboratory studies by supplying actinide concentration data along with information about chemical conditions 
present in the wastes and will test the numeric model using real wastes under conditions similar to those attained in the post-disposal phase.

An important caveat in this strategy is that although the STTP will sample actinide concentrations in subsets of parameter space that ought to resemble conditions of the disposal rooms, it is not possible to measure concentrations under truly authentic repository conditions. These conditions will evolve over hundreds of years, and it is not possible (or useful) to authoritatively predict a set of conditions at any given time in the post-disposal phase. This is why the source-term tests will be more useful for testing a source-term model than for directly predicting disposal room actinide concentrations.

It should be noted that other real waste test strategies exist that would deliver actinide concentration data to performance assessment directly. These include testing waste that is chemically representative of TRU waste in the DOE inventory and using waste types that would yield bounding values of actinide concentrations in the disposal rooms. This representative strategy fails because there is no way to identify any existing or synthetic waste that is statistically representative of the actinide source-term for future waste. The bounding strategy was initially considered for this test program, but due to the greater number of test conditions it must incorporate, this strategy requires a much larger test matrix and adds significant cost. It suffers, as does the current strategy, from inability to measure actinide concentrations under long-term disposal room conditions, but because the data from such a program would be directly used for performance assessment rather than used to evaluate a model, this flaw is much more serious. This does not rule out directly using data collected by the current test program for performance assessment, particularly if actinide concentrations remain at odds with model predictions or if they exceed the limits predicted by the model or the expert panel.

The laboratory studies of radionuclide chemistry and the source-term tests are viewed as complementary. It is useful to illustrate how they differ technically and programmatically by discussing tradeoffs between the two programs. The advantages of the laboratory program (vs. the STTP) are that test conditions are subject to greater control, allowing actinide mobilization mechanisms to be tested individually, and that actinide concentrations may be measured over a wide range of test conditions. These features allow one to construct a numeric source-term model from laboratory data. In addition, these data will be far less expensive than those collected by the STTP. However, the laboratory program is limited by its inability to test the numeric model with data from real wastes, which is scientifically desirable and significantly enhances the credibility of the model.

The principal advantage of the STTP is that it will measure actinide concentrations from real TRU wastes under repository-realistic conditions. This allows the program to collectively evaluate synergistic and/or antagonistic mechanisms of actinide mobilization, testing the numeric model developed by the laboratory program. A limitation of the STTP is that due to the short timescale on which the tests are run (compared with the 10,000 years over which 40 CFR $191 B$ is applicable), it cannot test all conditions possible in the disposal 
rooms. In addition, some conditions that influence actinide concentrations are not readily subject to control prior to testing and instead must be measured, adding to the cost of the experiments.

\subsection{Conditions of the Disposal Rooms}

It is expected that the disposal room conditions will be anoxic in the long term due to consumption of oxygen by aerobic bacteria and possibly corrosion of steel, though some local microenvironments may be oxic due to radiolysis. Both aerobic and anaerobic bacteria will be present, though their ability to metabolize waste components is not presently known or assumed. The quantity of brine in the rooms will depend on inflow rates, room gas pressures, and whether human intrusion releases Castile brine into the rooms, and will be limited by the extremes of humid and inundated rooms. The rooms will also contain actinides, and most of the activity will be from ${ }^{239} \mathrm{Pu}$ (and, at early times, from ${ }^{241} \mathrm{Am}$ ).

Possible conditions in Eh-pH space through which the disposal rooms may trend are shown in Figure 2. In general, anoxic corrosion and radiolysis compete to decrease or increase Eh, respectively. Microbial activity will generally render brine more acidic, and cement or grout will tend to increase $\mathrm{pH}$. The range of attainable Eh-pH space is limited by the acidities $\left(\mathrm{pK}_{\mathrm{a}} \mathrm{s}\right)$ of organic acids produced by the microbes, the basicity of the cement or grout in the waste or backfill (if any), $\mathrm{CO}_{2}$ fugacity in the rooms, and the upper and lower stability limits of water (with some allowance for overpotentials, shown as dashed lines on Figure 1). A difficulty with both measuring EMFs of and constructing speciation diagrams for reactions involving the formation and cleavage of metal oxygen bonds (e.g., actinyl ions) is that such reactions are thermodynamically irreversible and that in most systems speciation as a function of Eh is controlled by kinetics. To illustrate, the speciation diagram in Figure 1 represents equilibrium states of $\mathrm{Pu}$ as a function of $\mathrm{Eh}$ and $\mathrm{pH}$, and while it indicates that acidic and reducing conditions favor $\mathrm{Pu}(\mathrm{III})$, it does not imply that all $\mathrm{Pu}$ will be in the +3 state at, for example, an $\mathrm{Eh}$ of $0.0 \mathrm{~V}$ and a $\mathrm{pH}$ of 3 . In certain circumstances microbes can effectively serve as redox catalysts (Francis, 1990).

Halophilic and halotolerant bacteria have been identified in brines collected from the WIPP underground workings, and these microbial colonies can use cellulosic materials (which constitute a significant fraction of the total volume of TRU waste) as substrates for growth under both aerobic and anaerobic conditions. There are four major microbe-mediated processes that can take place in the disposal rooms after closure. First, fermentation can disproportionate polysaccharides (such as cellulose) into, among other species, alcohols, organic acids, and carbon dioxide. Denitrification can oxidize the organic products into $\alpha$-hydroxycarboxylic acids (such as lactic and citric acid) while reducing nitrate ion to $\mathrm{N}_{2}$ or $\mathrm{NH}_{3}$. Sulfate reduction can further oxidize these acids to $\mathrm{CO}_{2}$ while reducing sulfate to $\mathrm{H}_{2} \mathrm{~S}$. Finally, methanogenesis can reduce $\mathrm{CO}_{2}$ to methane $\left(\mathrm{CH}_{4}\right)$ in the presence of excess $\mathrm{H}_{2}$ (which may be generated in the disposal rooms by anoxic corrosion of steel and radiolysis of brine or organic waste materials). 
Microbial activity can affect actinide concentrations by causing changes in system $\mathrm{pH}$ and Eh, and producing chelating agents. Halophilic and halotolerant anaerobic bacteria may serve as redox catalysts by reducing $\mathrm{Pu}(\mathrm{VI})$ to either $\mathrm{Pu}(\mathrm{IV})$ or $\mathrm{Pu}(\mathrm{III})$ directly, or through an intermediate couple such as $\mathrm{Fe}^{3+} / \mathrm{Fe}^{2+}$. Microbial reduction of $\mathrm{U}(\mathrm{VI})$ to $\mathrm{U}(\mathrm{IV})$ has been postulated to account for observed immobilization of uranium in sludges (Francis et al., 1991). Denitrification in waste containing both nitrate (from process sludges) and cellulosics (from combustibles) may produce $\alpha$-hydroxycarboxylate chelating agents in significunt quantity. Sulfate reduction (using $\mathrm{SO}_{4}{ }^{2-}$ in brine) may further oxidize these compounds to $\mathrm{CO}_{2}$. Microbial degradation of cellulosics may also produce colloids capable of sorbing, and thus mobilizing, actinides.

Carbonate, hydroxide, and chloride are the ligands present in the disposal rooms in the greatest quantity, though the stability constants for their actinide complexes are estimated to be not nearly as great as those for complexes with organic ligands such as citrate or EDTA. Some of these ligands are in the waste inventory from decontamination procedures; others may be produced by the action of denitrifying bacteria on alcohols and organic acids. Sulfate-reducing bacteria may act as a sink for both natural and artificial chelating agents, oxidizing them to $\mathrm{CO}_{2}$.

The principal sorbents in the WIPP disposal rooms will be rust (from corroded drums), bentonite (assuming this is used as a backfill component), vermiculite used in drum packing, and possibly anhydrite contained in the Salado marker beds. Although the presence of sorbents can only serve to reduce actinide concentrations (unless these sorbents form mobile colloids), their effectiveness may be highly variable, since sorptive capacity will depend on such factors as $\mathrm{pH}$ and actinide speciation. Calcium oxide may also be added to the backfill to act as a getter material for $\mathrm{CO}_{2}$. It is not yet clear how the resulting increase in $\mathrm{pH}$ and calcium content of the rooms would affect actinide concentrations.

Colloidal suspension of actinides may occur as actinides in solution precipitate onto the surfaces of suspended particulates. Colloidally-sized particles are those that remain in suspension without appreciably settling and can be considered part of the liquid phase. Colloids are probably metastable in the disposal rooms, eventually either dissolving, precipitating, or becoming sorbed onto solid material. The definition of the size of a colloidal particle is somewhat arbitrary, and we have defined the maximum size of a colloid to be $1 \mu \mathrm{m}$. Corroded steel, exfoliated clays, and products of cellulose degradation can all serve as hosts for radiocolloids in the disposal rooms. They may also be produced by hydrolysis of soluble actinide salts. It is not yet clear under what conditions colloidal mobilization of actinides will be important, or if such conditions will be met in the repository.

\subsection{Conditions of the Test Containers}

To meet the objectives stated in Section 2.2 , the source-term tests would ideally start with these conditions: 
1. The tests would use real TRU waste from existing inventory at a DOE site. Using "synthetic" waste prepared by adding actinides to nonradioactive items typical of the waste category (transuranic content [TRUCON] code) being tested introduces an unacceptable bias, as the range of materials disposed of under a given TRUCON designation is unknown. Sampling bias is also introduced if waste conforming to a certain TRUCON designation is culled from a mixture of waste types. To avoid these problems, only waste that has already been identified as fitting the TRUCON designations required by the test matrix may be used in the experiments.

2. The tests would use containers that are large on the scale of waste heterogeneity. For all waste types, the test vessels must be large compared to the scale of the waste constituents (the articles that comprise the waste) so that the tests will reasonably reflect conditions typical of the waste type being tested. This requires using containers of at least $210 \mathrm{~L}(55 \mathrm{gal})$ volume for highly heterogeneous waste types such as combustibles and metals. Tests involving these waste types are referred to as "drum-scale" tests in the matrix (Appendix A). For more finely divided, heterogeneous wastes (e.g., sludges, pyrochemical salts), containers on the order of 2-5 L volume ("liter-scale" vessels) will suffice.

3. The wastes would be selected in a way that avoids experimental bias. Specifically, integer numbers of waste drums must be used to load the drum-scale containers. It will be difficult to load only a fraction of the contents of a drum without introducing bias in waste selection. Obviously, the liter-scale vessels must be loaded with a small fraction of the contents of a waste drum, but because these wastes are heterogeneous on a much smaller scale, this problem is not nearly as significant. However, the tests would be biased if all liter scale experiments for a given waste type were filled with material from a single waste drum. Therefore, each liter-scale waste sample must be taken from a different drum.

4. The tests would use brines collected from the WIPP underground because they contain microbial populations that are local to the repository. In reality, it will probably not be possible to collect enough natural brine from the underground to operate the tests using only WIPP brine. See Section 2.4.1.

5. The tests would include inventories of all elements of interest. The STTP is intended to determine concentrations of actinides ( $\mathrm{Pu}, \mathrm{Am}, \mathrm{Th}, \mathrm{U}, \mathrm{Np})$ that will be limited by the chemistry of the disposal room, rather than inventory.

6. The test matrix would include steel because it is a significant component of the disposal room contents. It affects Eh, sorption, and colloid generation. Most tests will contain iron, though some tests will be run without any iron to evaluate the effects of anoxic corrosion and colloid sorption by steel or rust on solution-phase actinide concentrations. The surface area of the added steel must equal that of a 55 gallon drum in the drum-scale tests and must be proportional to the fraction of drum 
volume occupied by the waste sample in the liter-scale tests. The steel must be thick enough to prevent complete corrosion during the first three years of the tests. See Section 3.3 for specific requirements.

7. The test matrix would include bentonite because it is a component of a proposed backfill material for the rooms. Certain waste types will be tested both alone and with added bentonite. This will test the effectiveness of the backfill material as a sorbent for actinides and will identify the potential for mobilization of actinides through adsorbtion onto exfoliated clay colloids.

8. The matrix would include some experiments run under high $\mathrm{CO}_{2}$ pressure. The rooms may fill with $\mathrm{CO}_{2}$ as cellulosics ferment, and the solubility of actinides under these conditions is highly relevant because $\mathrm{CO}_{2}$ is a complexing ligand for actinides. The maximum total pressure attainable in the disposal rooms from anoxic corrosion and microbial degradation of high-organic wastes is approximately 150 bar because higher pressures will exceed in situ lithostatic pressure (though pressures of up to $200 \mathrm{bar}$ may be attainable if the rooms can deform without fracturing the anhydrite beds). Tests with pressurized $\mathrm{CO}_{2}$ will determine if the lower solution $\mathrm{pH}$ and/or formation of actinide carbonate complexes from $\mathrm{CO}_{2}$ dissolution result in higher actinide solubilities. These tests will use $\mathrm{CO}_{2}$ overpressures of approximately 60 bar. Beyond this pressure, the increase of $\mathrm{CO}_{2}$ fugacity with pressure becomes much more gradual, and thus the decrease in $\mathrm{pH}$ with increased $\mathrm{CO}_{2}$ pressure (up to $200 \mathrm{bar}$ ) is minor (Appendix B). The actual pressures to be attained in the disposal rooms will be determined by such factors as waste inventory, microbial processes, gas generation rates, permeability of the anhydrite beds, and the temperature of the rooms.

9. The test containers would be leak tight. After the repository is sealed, the disposal rooms will be airtight, and unless brine radiolysis prevents them, processes such as anoxic corrosion and anaerobic microbial activity will ensue in partially or completely brine-filled rooms once oxygen is depleted. A container with an excessive rate of oxygen ingress will not achieve these conditions and thus cannot realistically simulate post-closure disposal room conditions.

10. The temperature of the test environment would be controlled. The tests must be held at a reasonably constant temperature, the average of which should approximate the in situ repository temperature of the WIPP (ca. $30^{\circ} \mathrm{C}$ ). Wide excursions in external temperatures may significantly perturb microbial activity. Aside from maintaining the temperatures of the rooms in which the tests are conducted to $30^{\circ} \mathrm{C}$, no attempt should be made to control the internal temperatures attained within the test vessels; again this may unduly influence microbial activity. 


\subsubsection{Test Compromises}

Because only finite time and budget exist for conducting these tests, we must introduce certain compromises:

1. The test vessels must be agitated. Diffusion cannot be relied upon to bring actinide concentrations to a steady state. A quiescent system with multipoint sampling would increase analytical costs tremendously without improving data quality. The agitation system employed must ensure that all solid material has opportunity to interact with the brine and that actinide concentrations in the brine are approximately uniform throughout the test containers.

2. The waste must be "spiked" or augmented with actinides, as the actinide content of TRU waste currently in inventory consists almost exclusively of Pu and Am. Nondestructive analysis techniques such as passive-active neutron (PAN) spectroscopy can measure approximately how much $\mathrm{Pu}$ is in each drum, and $\mathrm{Am}$ content can be estimated from Pu/Am ratios (if known). $2.5 \mathrm{~g} \mathrm{Pu} / 100 \mathrm{~L}$ of brine will suffice to yield $10^{-4} \mathrm{M}$, which is estimated by an expert panel elicitation (Trauth et al., 1991) to be the upper limit of $\mathrm{Pu}$ concentration in the disposal rooms. A loading level of $5 \mathrm{~g}$ Pu per 55 gal. drum meets this requirement. Loadings of the other actinides (Th, U, $\mathrm{Np}, \mathrm{Am}$ ) must be brought to this level by spiking with actinide salts. It is unrealistic, however, to spike with Am to this level in all tests because this would yield an activity of 20 times that of the average drum. (The median alpha activity of an equivalent drum is approximately 1 curie (WPD, 1991b), the equivalent of $14 \mathrm{~g}$ of weapons-grade $\mathrm{Pu}$. $5 \mathrm{~g} \mathrm{Am}-241$ has an activity of $17.5 \mathrm{Ci}$, or the equivalent of ca. $250 \mathrm{~g}$ weapons-grade Pu.) This could easily cause a condition more oxic than is reasonable for the WIPP disposal rooms, and a lanthanide analogue of Am, such as $\mathrm{Nd}$, will have to be used for spiking in nearly all tests.

Tests must also be spiked with $\mathrm{U}$, Th, and $\mathrm{Np}$. These are very minor constituents of the current TRU waste inventory that will become significant during the 10,000 years following decommissioning. It should be noted that $\mathrm{Th}, \mathrm{U}, \mathrm{Np}$, and $\mathrm{Nd}$ (or $\mathrm{Am}$ ) serve as chemical analogs for the four water-stable oxidation states of $\mathrm{Pu}$ : $\mathrm{ThO}_{2}(\mathrm{aq})$ for $\mathrm{Pu}(\mathrm{IV}), \mathrm{NpO}_{2}{ }^{+}$for $\mathrm{Pu}(\mathrm{V}), \mathrm{UO}_{2}{ }^{2+}$ for $\mathrm{Pu}(\mathrm{VI})$, and $\mathrm{Nd}^{3+}$ (or $\mathrm{Am}^{3+}$ ) for $\mathrm{Pu}(\mathrm{III})$. Acquiring data for these elements will assist in preparing a model that will predict mobilities for Pu under different conditions of Eh than those actually encountered in a given sample.

3. The material in the test vessels must be completely inundated with brine, except for a small headspace for gas collection. This is a limiting condition for the disposal rooms, but if the test vessels are not completely filled, it will not be possible to ascertain that all of the waste and actinides are in contact with the brine. 
4. Brines collected from the WIPP underground will be mixed with synthetic brine because the quantity of natural brine available is not sufficient for conducting the STTP. All tests will therefore contain a bacterial inoculum prepared from brines collected from the WIPP underground, rock salt obtained from both the underground and the surface of the WIPP Site, and material from surface lakes in the vicinity of the WIPP Site. A recipe for the inoculated brine is described in Appendix C.

\subsection{Test Matrix}

The STTP is designed to measure radionuclide concentrations from the many sets of conditions that may be attained in the WIPP disposal rooms. This requires selecting waste types that will generate a broad spectrum of mobility-controlling variables in environments expected in the disposal rooms.

The test matrix is designed to quantify the sensitivity of actinide mobilities to these variables as they occur in existing waste types. The range of chemical environments possible within a given waste type cannot be known with any certainty, and it is not reasonable to attempt to define a "representative sample" for a class of TRU waste. Rather, this program is intended to sample actinide concentrations principally from those waste types that are expected to yield combinations of influences typical of those the: may be encountered in TRU waste stored in WIPP disposal rooms. These results can then be used to test the validity of laboratory data-derived numeric models to predict actinide mobility in TRU waste under disposal room conditions.

The test matrix uses waste types that collectively provide a set of unique conditions that sample each of the influences that affect steady-state concentrations of actinides. The waste types tested in the proposed matrix (Appendix A) are categorized by TRUCON code (Westinghouse, 1989) and are selected from these categories based on listed contents, process knowledge, and actinide content. Three replicates of each experiment are required so that probability intervals can be established for the actinide concentrations from each set of conditions tested.

1. combustibles, TRUCON 116/216 (D1-3)

Of principal interest in these tests are the effects of cellulose degradation on actinide solubility. Aerobic oxidation and fermentation will serve to lower system Eh. Denitrification may produce complexing agents such as citrate and lactate. Complexing agents may already be present in the waste from decontamination activities. These will make up the bulk of complexing agents withdrawn from the leachate at early times. 
2. combustibles with bentonite backfill, TRUCON 116/216 (D4-6)

The results from these experiments can be compared directly with those from D1-3, measuring the effectiveness of the backfill in removing actinides from solution and indicating whether the bentonite itself presents a significant colloid source.

3. "enriched" combustibles, TRUCON 116/216 (D7-9)

Although fermentation and denitrification are predicted to yield complexing agents from cellulose, it is conceivable that this condition may not occur within the test period. These experiments test the effects on solubility of a system containing both "naturally occurring" ligands (such as lactate) and those introduced as part of the waste stream (such as EDTA). In addition, these tests will follow the evolution of ligand concentration over time to observe if microbial activity consumes or generates complexing agents.

4. combustibles with solidified aqueous inorganic process sludge, TRUCONs 116/216 and $111 / 211$ (D10-12)

In denitrification, cellulose or its fermentation products are oxidized by bacteria capable of using nitrate as an electron acceptor. The $\mathrm{NO}_{3}{ }^{-}$is in turn reduced to $\mathrm{N}_{2}$ or $\mathrm{NH}_{3}$. Denitrifying bacteria can oxidize organic acids to $\alpha$-hydroxy acids, which are effective complexing agents. The presence of nitrate in process sludges may be significant in promoting this process in combustible waste.

5. metals, TRUCON $117 / 217$ (D13-15)

Metals capable of corroding under anoxic conditions will reduce system Eh below the stability limit of water, possibly stabilizing $\mathrm{Pu}(\mathrm{III})$ in solution. Both Fe (from mild steel) and $\mathrm{Al}$ will anoxically corrode in brines. Less active metals such as $\mathrm{Cu}$ and $\mathrm{Pb}$ may also corrode if $\mathrm{H}_{2} \mathrm{~S}$ (from sulfate reduction) is present.

6. solidified aqueous inorganic process sludge, TRUCON 111/211 (L1-3)

This sludge is principally obtained in the course of wastewater treatment, in which $\mathrm{Pu}$ and other actinides are coprecipitated with an iron floc, then filtered. These tests will thus determine the effectiveness of the floc as a sorbent for actinides. The floc may also be capable of generating colloids that can serve as hosts for suspended radionuclides.

7. solidified aqueous inorganic sludge, TRUCON 111/211 with $\mathrm{CO}_{2}$ (L4-6)

These tests will be conducted with a $\mathrm{CO}_{2}$ overpressure of up to 60 bar. It is assumed that actinide solubilities can be affected both by decreased $\mathrm{pH}$ and by complexation by carbonate. The results from these tests will be directly comparable to those from tests L1-3.

8. solidified aqueous inorganic sludge, TRUCON 111/214, no iron (L7-9)

Corroding steel in the disposal rooms provides a possible sink for actinides through sorption. However, it is possible that $\mathrm{CO}_{2}$ in the rooms may passivate steel by 
forming a surface layer of siderite $\left(\mathrm{FeCO}_{3}\right)$, which would render much less iron oxide available for sorbing actinides. These experiments test the effect on actinide concentration of removing iron oxides from the system, eliminating sorption of actinides by these phases.

9. solidified aqueous inorganic sludge, TRUCON 111/211, no iron, Am-241 spiked (L10-12)

In addition to providing a source of sorbents, steel corrosion also lowers brine Eh in its vicinity. Without steel (or other active metals), the oxidizing effects of radiolysis dominate the Eh of the system. These experiments measure actinide concentration, and possibly speciation, under the most oxic conditions reasonably attainable in the rooms.

10. absorbed organic liquids, TRUCON 112/212 (L13-15)

These experiments will determine if high concentrations of organic solvents and reagents in the brine significantly promote dissolution or suspension of actinides. If the waste contains exclusively solvent residues their effect will be minimal, but if chelating agents, extractants, or detergents are present their effect on actinide concentration could be quite significant.

11. absorbed aqueous laboratory waste, TRUCON 113 (L16-18)

Chelating agents and extractants in this waste type may increase actinide solubility.

12. cemented inorganic particulates, TRUCON 114/214 (L19-21)

These tests will mainly examine the effects of increased $\mathrm{pH}$ on actinide solubility. It is also possible that actinides may become incorporated into cementitious phases, rendering them less soluble. Cementing certainly affects the leach rate, that is, the rate at which actinide ions can come into equilibrium with the brine. Though this effect may not be significant at long timescales, a highly retarded leaching rate would make data from these tests difficult to interpret, and the cemented material will have to be crushed before use.

13. cemented organic sludge, TRUCON 126/226 (L22-24)

These tests combine the factors in (10) with the possible presence of complexing or chelating agents, which are generally more effective at the higher $\mathrm{pH}$ values caused by the cement.

14. pyrochemical salt waste, TRUCON 124/224 (L25-27)

This waste type contains few actinide-concentration controlling influences and is thus effective for individually testing the effects of materials other than wastes that are present in the rooms, such as iron, backfill, and $\mathrm{CO}_{2}$. 
15. pyrochemical salt waste (TRUCON 124/224) with bentonite backfill (L28-30) These tests address the effectiveness of bentonite as an actinide sorbent in the presence of high concentrations of divalent ions (particularly $\mathrm{Ca}^{2+}$ ) that compete with the actinides for sorption sites on the clay particles.

16. pyrochemical salt waste (TRUCON 124/224) with $\mathrm{CO}_{2}$ (L31-33)

As with tests L4-6, these experiments will test the effects of lower $\mathrm{pH}$ and carbonate complexation on actinide solubility. The results from these tests and L25-27 can be compared to determine the significance of $\mathrm{CO}_{2}$ by itself as a solubility-controlling influence.

17. pyrochemical salt waste (TRUCON 124/224), no iron (L34-36)

These will test the effectiveness of steel corrodant as a sorbent for actinides.

18. pyrochemical salt waste (TRUCON 124/224), no iron, Am-241 spiked (L37-39)

As is the case in (9), the greater than typical alpha activity of this matrix (due to ${ }^{241} \mathrm{Am}$ ) increases the rate of brine radiolysis, rendering the system more oxic, as the $\mathrm{H}_{2}$ produced is relatively inert. The oxidizing products of radiolysis (such as $\mathrm{O}_{2}$, $\mathrm{H}_{2} \mathrm{O}_{2}, \mathrm{OCl}^{-}$) can in turn corrode steel, and the concentrations of these species in brine w'ill be determined by the relative rates of brine radiolysis and oxic corrosion i' 1 the system. These tests will determine whether steel corrosion or radiolysis is the dominant influence on system Eh, and therefore on actinide speciation.

The test matrix in Appendix $\mathrm{A}$ includes all combinations of mobility-influencing variables sufficiently unique to require testing. Although certain waste types that do not appear in the matrix appear to be unique, the conditions they would yield in the test vessels would be similar to those wastes already tested. These include:

1. RH-TRU. No remotely handled (RH) TRU waste is currently being considered for testing in this program due to the increased difficulties involved in handling the test containers and leachate from these materials. It is unlikely that the enhanced $\beta$ and $\gamma$ activity in RH TRU waste will significantly impact brine chemistry because these types of radiation have a much lower linear energy transfer than $\alpha$ particles, limiting the impact of fission products on brine radiolysis. In addition, data on the concentrations of fission products are not currently considered to be important to demonstrating compliance with $40 C F R 191 B$ and may be estimated from laboratory data if the need arises.

2. Pu-238. Although a significant amount of alpha activity in the initial inventory is from ${ }^{238} \mathrm{Pu}$ (used as heat sources in radioisotope thermoelectric generator [RTG] systems), there is no intrinsic chemical difference between this isotope and ${ }^{239} \mathrm{Pu}$. The indirect effects of higher alpha activity and consequently more intense radiolysis on system Eh and actinide mobilization will be explored in the ${ }^{241} \mathrm{Am}$-enriched test 
vessels, and there is therefore no need to include ${ }^{238} \mathrm{Pu}$-containing waste in the test matrix.

3. Modified waste forms such as grouted, incinerated, or vitrified waste are not currently in the inventory. Although these waste types may create conditions in the test containers that are not identical to those accessed in the rest of the matrix (such as biodegradable organics in an alkaline medium), these conditions will fall within the scope of the laboratory tests, and it is likely that these conditions will inhibit rather than provoke actinide dissolution. Also, these waste types do not exist in significant quantities in the current TRU Waste inventory.

\subsection{Analytical R\&quirements}

\subsubsection{Leachate Sampling}

The goal of leachate sampling is to recover brine from the test vessels such that leachate characterization (Section 2.6.2) can determine the actinide content and composition of the brine as it existed in the vessel at the time of sampling. The leachate inust therefore be sampled and stored in a way that prevents changes in the sample prior to analysis. For example, this means that the leachate cannot be exposed to air and that the walls of the sample container must be sufficiently inert to prevent sorption of actinides. Also, samples cannot be chemically treated to improve their stability (e.g., with respect to precipitation) because this will obviously alter the composition of the brine matrix. Therefore, the leachate must be analyzed as soon as possible after sampling and before sample deterioration becomes significant.

It is expected that actinide concentrations in the test vessels will reach a steady state within the duration of the STTP. It is anticipated that the tests will be operated for two to three years. The test design permits individual tests to be operated for longer periods at the discretion of the SNL principal investigator. This steady state differs from true chemical equilibrium in that the concentrations may be held steady by some condition that is itself transient, such as microbial activity or radiolysis. It is important, though, that leachate is sampled from each container with sufficient frequency and duration to demonstrate that a steady state has been reached at the end of the experiments. It is likely that sampling will be accelerated at early times (approximately the first three months) because the actinide concentrations in a given test container will initially be far from steady-state conditions, causing potentially large changes in concentration during this period. 


\subsubsection{Leachate Characterization}

The objectives of leachate characterization are to measure actinide concentrations in the brine and to quantify the components of the brine that influence actinide mobility. To summarize, leachate characterization requires measuring actinide conceritrations, $\mathrm{pH}$, Eh, quantity and type of radiocolloids present in suspension, identifying and quantifying complexing agents, and determining concentrations of metal ions capable of competing with actinides for active sites on complexing and sorbing agents. A complete description of analytical requirements is given in Section 4.2.

The precision required for measuring actinide concentrations is determined by the sensitivity required by the numeric model. As this model is no more precise than the laboratory data that comprise it, which is typically $\pm 10 \%$ of actinide concentration, this precision is sufficient. The detection limit is defined by performance assessment sensitivities. For a given concentration of an isotope, one can plot a range of possible releases, depending on assumptions made about the type of intrusion made and whether the actinides experience chemical retardation in the Culebra (Figure 3a). For the purpose of defining detection limits, we make the conservative assumption that no retardation takes place in the Culebra and that the detection limit corresponds to the minimum concentration yielding a normalized release of $10^{-2}$ in an E1E2 (double borehole) intrusion scenario (Figure 3b). For ${ }^{241} \mathrm{Am}$ and ${ }^{239} \mathrm{Pu}$, this corresponds to a concentration of approximately $10^{-10}$ molar. For the other elements (Th, $\mathrm{U}$, and $\mathrm{Np}$ ), the minimum molarities run from $10^{-9}$ to $10^{-8}$; however, because these elements are used as oxidation state analogs for $\mathrm{Pu}$, their detection limits should also be $10^{-10} \mathrm{M}$.

The detection limits for the species contributing to actinide mobility (e.g., colloids, complexing agents) are not as rigorous because the ratios of actinide mass to total mass of carrier species will be small. Therefore, detection at the $1 \mathrm{ppm}$ level is required for inorganic and organic anions that are capable of complexation. A detection limit of $10^{-7} \mathrm{M}$ for $\mathrm{Pu}$ oxidation state speciation is set by the limits of the technique. Concentrations of suspended colloids are relevant only if they actually are carrying actinides; this is again more significant in the leachates with higher actinide concentrations. It is not possible to rigorously define the upper and lower limits of colloidal size that separate particles in this size range from suspended particulates and dissolved molecular or ionic species. The lower limit will essentially be defined by the experimental requirement of using a filter of sufficient pore size such that filtration takes place at a finite rate. It is expected that $20 \mathrm{~nm}$ will be smaller than all of the colloidal particles in the leachate, with the possible exception of hydrated $\mathrm{PuO}_{2}$ colloids at very early times in the experiments. The available limits of precision and detection for suspended actinides are expected to depend on the nature of the host particle, but a detection limit of $10^{-7}$ moles of suspended actinide per liter of leachate will meet the needs of the program and should be achievable in most samples.

The concentrations of metal ions other than actinides are of interest as well because they can compete with actinides for active sites in chelating agents (which tends to depress solubility) or in sorbents (which tends to enhance solubility). The principal competing ions 
'dISS әપІ U! pəsn

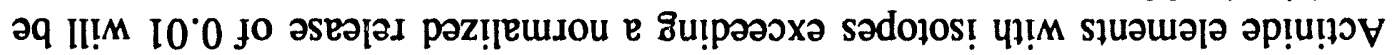

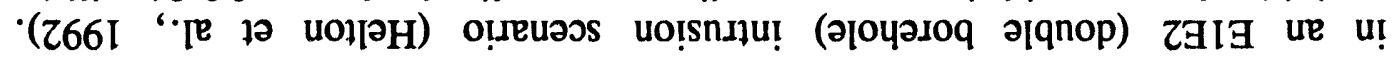

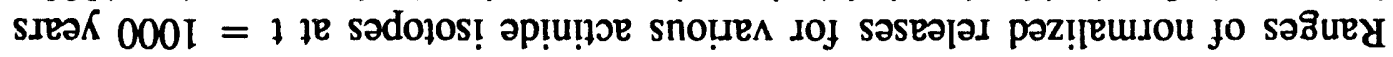

•eE วมกริ!ฺ

0.0 ssi-z†c9-|81

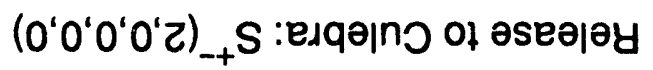

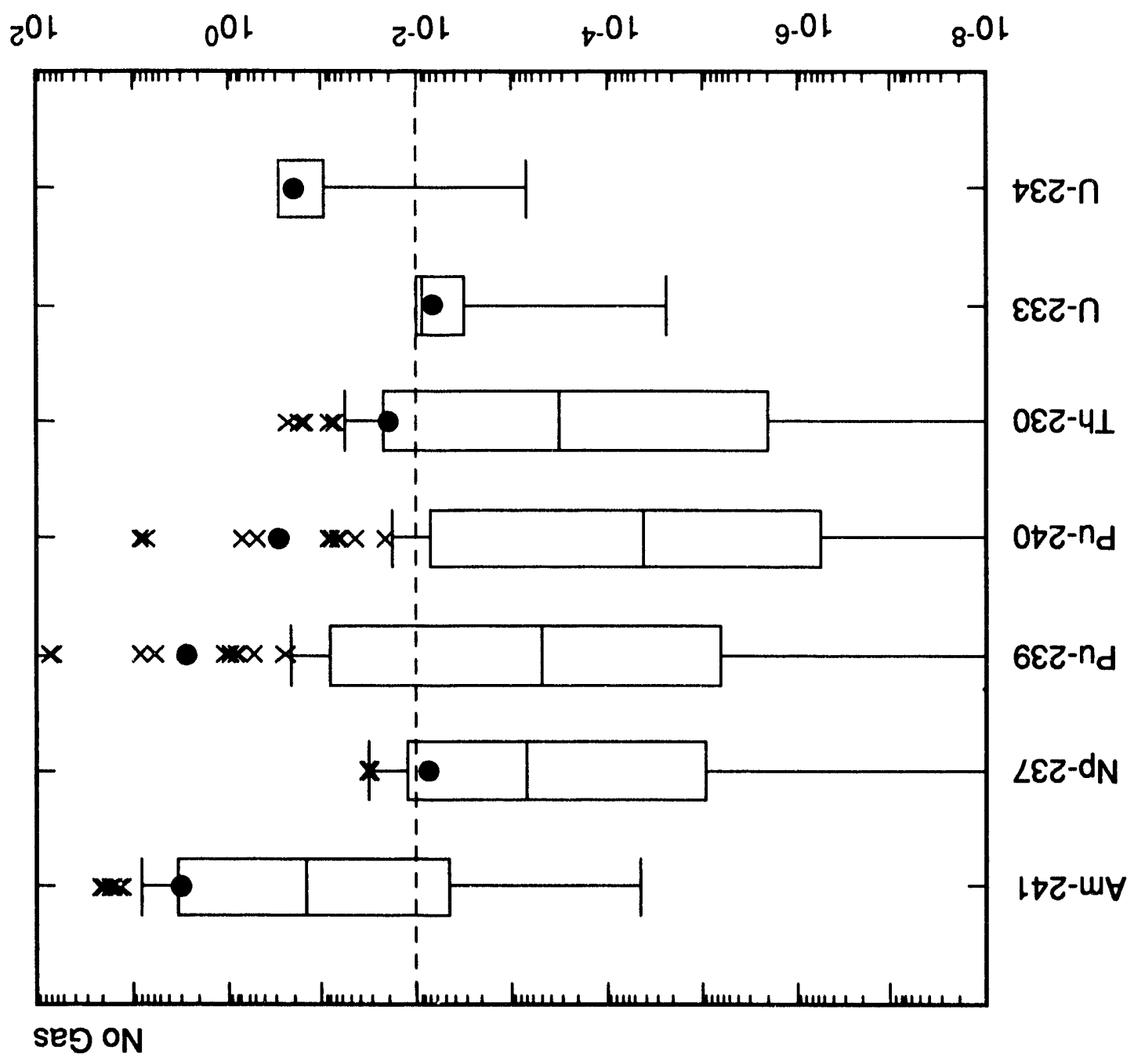



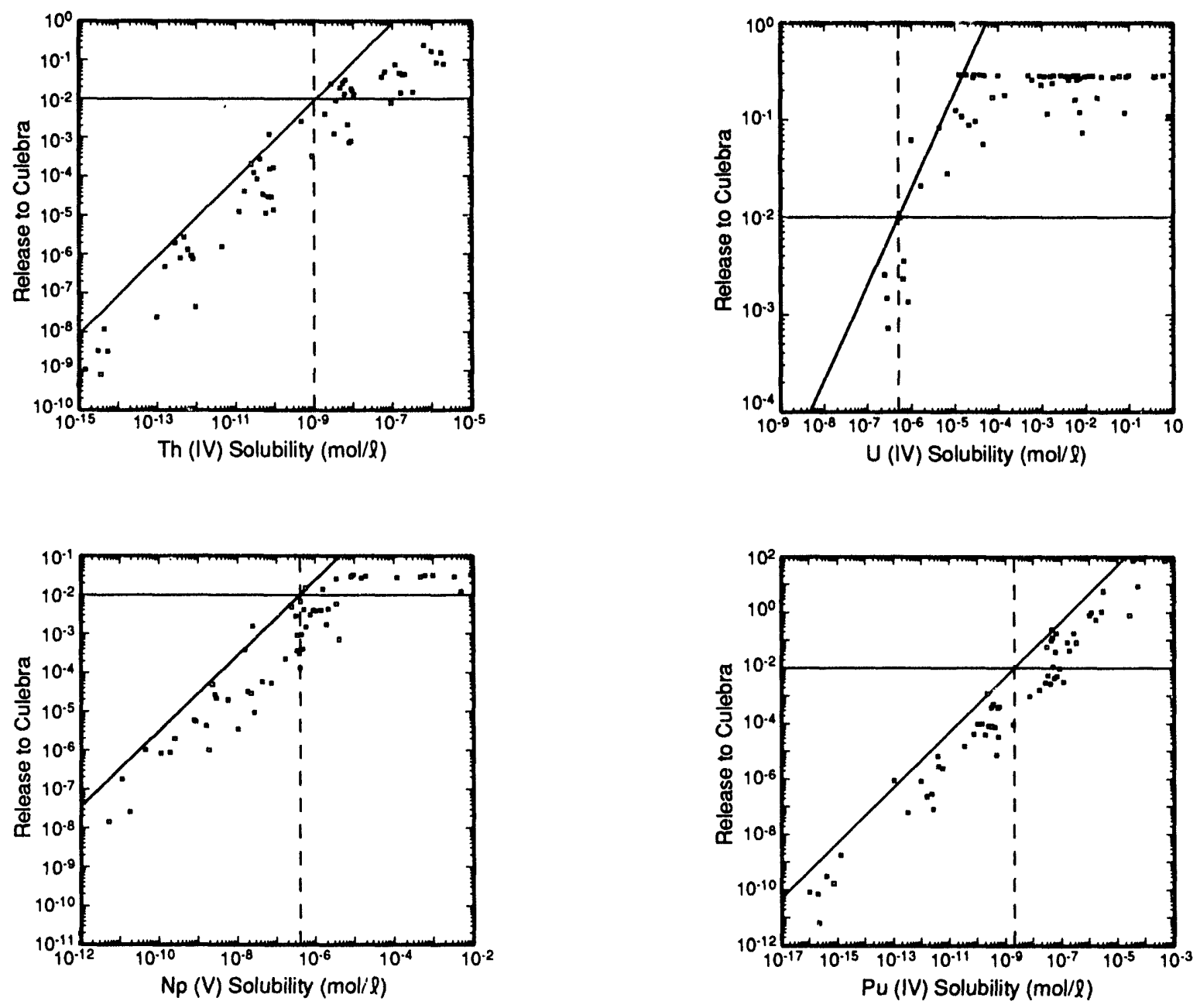

TRI-6345-197-0

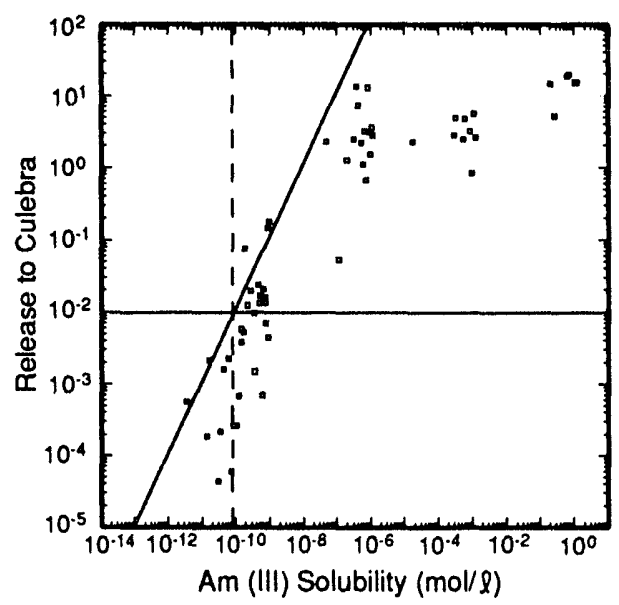

Figure 3b. Plots of normalized release vs. solubility for Th (IV), U (IV), Np (V), Pu (IV), and Am (III) in an E1E2 (double borehole intrusion scenario with no retardation in the Culebra at $t=1000$ years (See Appendix D). The minimum solubility yielding a release of 0.01 under these conditions is used to define detection limits for these actinides in the leachate. 
will be $\mathrm{Fe}$ and $\mathrm{Al}$, and possibly $\mathrm{Mg}$. $\mathrm{Pb}$ (II) is similar in chemical behavior to $\mathrm{Ca}$ and may be present in the leachate if corrosion of metallic lead (used in shielding) is significant. Competition from $\mathrm{Fe}$ (III) and $\mathrm{Al}$ (III) will occur if test conditions permit corrosion of these metals. The nonradioactive metals of analytical interest are thus $\mathrm{Ca}, \mathrm{Mg}, \mathrm{Pb}, \mathrm{Fe}$, and $\mathrm{Al}$. Competing ion effects will principally affect actinide concentrations at higher metal concentrations, and detection limits of $100 \mathrm{ppb}$ for these ions are sufficient.

\subsubsection{Gas Measurement}

The purpose of measuring gas composition inside the test containers is to determine whether anoxic corrosion of steel is taking place and to moritor microbial activity. Gas data are essential to the latter because the principal modes of microbial metabolism (fermentation, denitrification, sulfate reduction, methanogenesis) will be identified only by their gaseous products. It must be noted that gas production rates are expected to be accelerated by agitation and inundation and that rate data from the source-term experiments are not appropriate for predicting gas-generation rates in the post-closure repository.

Because both steel corrosion and microbial processes are controlled by system Eh, gas composition is a qualitative Eh indicator. Gas should therefore be sampled simultaneously with the leachate. It may be desirable to sample gas more frequently than this because sampling frequency will ultimately be dictated by evolution of composition within the test vessels. Data are required for gases associated with corrosion behavior $\left(\mathrm{H}_{2}, \mathrm{CO}_{2}\right)$, microbial activity $\left(\mathrm{CO}_{2}, \mathrm{CO}, \mathrm{CH}_{4}, \mathrm{~N}_{2}, \mathrm{H}_{2} \mathrm{~S}\right)$, and leakage and radiolysis $\left(\mathrm{O}_{2}, \mathrm{H}_{2}, \mathrm{~N}_{2}, \mathrm{CO}, \mathrm{CO}_{2}\right)$. Detection limit requirements are based on the sensitivities of corrosion and microbial processes to trace gases (e.g., $\mathrm{CO}_{2}, \mathrm{O}_{2}$ for corrosion, $\mathrm{O}_{2}$ for microbes). It is estimated that a $1 \mathrm{ppm}$ limit for all gases will suffice. 


\subsection{TEST PREPARATION REQUIREMENTS}

\subsection{Waste Selection}

Prior to waste characterization, it is desirable to learn as much as possible about the contents of the waste drums used in this experiment. Initially, it will be necessary to rely on the reported contents of the container, process knowledge, and TRU waste content. The reported ${ }^{239} \mathrm{Pu}$ (or weapons-grade $\mathrm{Pu}$ ) content of each 55-gal. waste container selected for further characterization must be at least $5 \mathrm{~g}$. Five grams of $\mathrm{Pu}$ in $210 \mathrm{~L}$ of brine would yield a $10^{4} \mathrm{M}$ solution if it were to completely dissolve." The other required actinides (Th, U, Np, and Am) are desirable constituents, but are not present in all waste types and must be added during test container loading as needed (see Section 2.3). ${ }^{239} \mathrm{Pu}$ should be the predominant plutonium isotope in the waste, though the precise value of the ${ }^{239} \mathrm{Pu} /{ }^{240} \mathrm{Pu}$ isotope ratio is not very significant. This test program does not require any tests with ${ }^{238} \mathrm{Pu}$, which would create additional difficulties in handling the test containers and leachate samples without yielding any technical benefit. The effects of higher alpha activity and consequently more intense radiolysis on system Eh and actinide mobilization will be explored in ${ }^{241} \mathrm{Am}$-enriched test vessels (see Section 2.5).

To ensure that at least $5 \mathrm{~g}$ Pu will be included in each test container and to prevent possible experimental bias, the complete contents of a waste container will be used in the drumscale tests. At the discretion of the SNL principal investigator or his/her designee, specific items may be culled from the waste and discarder.. Samples for the liter-scale tests will be obtained from waste containers individually; that is, a single waste container can supply material for only one liter-scale test. Samples may be withdrawn from densely packed, semi-homogeneous waste forms (e.g., cemented sludges) by coring.

For the subtests using "enriched" waste (Section 2.5), waste containers should be selected appropriately according to content lists and knowledge of process history, if any.

\subsection{Pre-Test Waste Characterization}

Prior to opening the waste drums, a radionuclide assay is to be performed using passiveactive neutron (PAN) spectroscopy-based nondestructive analysis (NDA), or a technique yielding equivalent or better precision. This will ascertain whether sufficient quantities of $\mathrm{Pu}$ (principally

'Some preliminary results have shown transient Pu concentrations of up to $10^{-3} \mathrm{~mol} / \mathrm{L}$ in Brine A. However, supplying sufficient $\mathrm{Pu}$ to yield a $10^{-3} \mathrm{~mol} / \mathrm{L}$ solution upon complete dissolution would require $50 \mathrm{~g}$ Pu per drum equivalent of waste, which is not representative of the alpha activity of the drums in the current DOE inventory. If brine analyses indicate that complete dissolution has been attained in one or more test containers, they may be spiked with additional Pu per Section 3.4.2. 
${ }^{239} \mathrm{Pu}$ ) are present for conducting the tests. Total $\mathrm{Pu}$ and Am may be estimated from the quantity of ${ }^{239} \mathrm{Pu}$ measured and ${ }^{239} \mathrm{Pu} /$ total $\mathrm{Pu}$ and ${ }^{241} \mathrm{Am} /{ }^{239} \mathrm{Pu}$ ratios, if known. Waste that has been previously assayed using PAN or a more precise technique need not be re-assayed, provided that the measurements were performed at a level of quality assurance that is compatible with the WIPP Quality Assurance Program Plan (QAPP). NDA must be performed individually on all waste samples to be used for the liter-scale tests to ensure that each sample contains a sufficient quantity of $\mathrm{Pu}$.

The contents of the drums will then be examined using real-time radiography (RTR) to ensure that the selected drums meet both the descriptions of their content code and the WIPP Waste Acceptance Criteria (WAC). Drums that do not fit their TRUCON or do not meet the WIPP WAC will not be used for testing. The drums will then be opened, their non-nuclear contents identified visually, and in the case of heterogeneous waste types such as combustibles and metals, individual items will be weighed and cataloged. Waste characterization will require removing all levels of containment so that individual items may be visually characterized. Specific data quality objectives for visual characterization will be defined in the Test Plan.

Non-permeable (grouted or cemented) wastes must be broken or ground to allow intimate contact between the actinides in the solids and the liquid phase. Cemented wastes should be broken into pieces of a size that is reasonably expected to be fully leachable in brine during the first year of testing. This size criterion will be determined through an experiment performed prior to test initiation that measures the leach rate of cesium ion from portland cement and Envirostone into WIPP brine (Appendix E).

Adequate visual and physical characterization of the heterogeneous waste types will require removing all levels of containment so that individual items can be examined and identified. Any sealed containers present will need to be exfoliated to permit access of the brine to container contents.

\subsection{Test Container Loading}

Drum-scale test containers will contain the contents of a standard 55 gal. waste drum and allow at least $40 \mathrm{~L}$ residual volume to accommodate the brine mixture. Bentonite will be added to the appropriate test containers during container loading. The desired brine-backfill proportion will be determined by experiments that will measure brine-solid ratio and liquid filterability as a function of the brine-backfill proportion (Appendix F). Brine will be added until the remaining headspace occupies less than $10 \%$ of the container volume. The level of brine in the test containers must be monitored during the filling procedure to prevent overflow. Provisions must be made to control floating objects while the containers are being filled with brine by, for example, placing a screen in the container top. 
The ambicnt-pressure liter-scale experiments must be loaded so that at least $1 \mathrm{~L}$ of free liquid volume remains after brine addition and mixing. The high-pressure experiments will contain at least $0.5 \mathrm{~L}$ free liquid volume after mixing. A discussion of brine/sludge mixing experiments that will be used to estimate the initial waste/brine ratio may be found in Appendix F.

The total loading of actinides in each test container must be at least $2.5 \mathrm{~g}$ per $100 \mathrm{~L}$ of test container volume. It is anticipated that ${ }^{232} \mathrm{Th},{ }^{238} \mathrm{U},{ }^{237} \mathrm{~Np}$, and ${ }^{241} \mathrm{Am}$ (or $\mathrm{Nd}$, using $1.5 \mathrm{~g}$ per $100 \mathrm{~L}$ ) will be used to spike the containers that have less than $5 \mathrm{~g}$ per drum equivalent of these elements. Either the chloride or sulfate salts are suitable for use as spiking agents. Thorium should be added as the tetravalent ion (e.g., $\mathrm{ThCl}_{4}$ ), neptunium as $\mathrm{NpO}_{2}{ }^{+}$(e.g., $\mathrm{NpO}_{2} \mathrm{Cl}$ ), uranium as $\mathrm{UO}_{2}{ }^{2+}$ (e.g., $\mathrm{UO}_{2} \mathrm{Cl}_{2}$ ), and $\mathrm{Nd}$ as $\mathrm{Nd}^{3+}$ (e.g., $\mathrm{NdCl}_{3}$ ). The weights of each actinide salt should be known to within at least $0.5 \%$.

Certain liter-scale tests on sludges and pyrochemical salt waste (Appendix A) will use the same $2.5 \mathrm{~g} / 100 \mathrm{~L}$ criterion for ${ }^{241} \mathrm{Am}$ in addition to the other four actinides. Test containers falling short of this level may be spiked with an americium salt such as $\mathrm{Am}_{2}\left(\mathrm{SO}_{4}\right)_{3}$. The total amount of Am required for spiking will depend on the chosen size of the liter-scale containers, but should not significantly exceed $0.75 \mathrm{~g}(5 \mathrm{~L} \times 6$ vessels $\times 2.5 \mathrm{~g} / 100 \mathrm{~L})$.

The brine to be used throughout the test program is a mixture of synthetic Brine A with an inoculum consisting from brine collected from the WIPP underground, salt from the WIPP tailings pile, and mud from surrounding saline lakes (Appendix C). The temperature of the test vessels must be monitored externally while the brine mixture is being added to the test containers because temperature excursions caused by exothermic reactions may harm microbes in the WIPP brine if sufficiently severe, e.g., to temperatures beyond $50^{\circ} \mathrm{C}$. Such excursions (which are unlikely except in waste that contains uncured cement) may be mitigated by slowing the brine addition rate or by placing the vessel in a water bath. After the containers have reached thermal equilibrium, they will be topped off with the appropriate brine mixture, then sealed. The volume of brine in the test container must be known at least to within $1 \%$ of the total added brine volume and should be measured at $30^{\circ} \mathrm{C}$. The headspace within the test vessels should allow sufficient space over the brine for gases to accumulate without overpressurizing the container, but it should not allow the waste to float in such a way that it cannot be efficiently agitated.

Waste forms requiring enrichment with complexing and chelating agents will be spiked with both natural (occurring from cellulose degradation) and synthetic (added to waste stream) ligands. Complexing agents in the waste inventory that may influence actinide solubilities in brine include acetamide, acetate, ascorbate, citrate, bis(2-ethylhexyl) phosphoric acid (DHP), EDTA, 2-hydroxybutyrate, 8-hydroxyquinoline, lactate, oxalate, 1,10 phenanthroline, thenoyltrifluoroacetonate (TTA), and thiocyanate. Several of these ligands will 
be used to spike the "enriched" combustibles tests (D7-9) based on their stability constants with actinides and their estimated abundance in the DOE inventory. It is currently thought that these ligands will include acetate, ascorbate, citrate, EDTA, oxalate, and thiocyanate. The identities and quantities of ligands will be finalized prior to test initiation, based on laboratory screening studies."

The STTP requires that most test vessels (drum and liter-scale) contain iron or mild steel to simulate the effects of container corrosion in the post-closure WIPP disposal rooms. Several liter-scale tests will be run without iron to determine if the iron is significant in generating Fe-based colloids, removing Pu-based colloids, or controlling solution Eh. For the drum-scale tests, the surface area of the added steel must be equivalent to that of a standard 55-gal. waste drum, which is approximately $4 \mathrm{~m}^{2}$ (considering both internal and external surface). The literscale tests require corrodant with area equal to $\left(4 \mathrm{~m}^{2}\right)$ (waste volume $/ 210 \mathrm{~L}$ ). The corrodant must be thick enough so that corrosion will be incomplete after five years of testing. A sample calculation that may be useful for selecting a corrodant mesh is given in Appendix G.

It will be necessary to remove oxygen from the test containers after they are loaded with waste and brine. Procedures and criteria for oxygen removal will be developed and documented by SNL and LANL prior to test initiation and will be approved by the SNL principal investigator or his/her designee.

\subsection{Design Requirements}

The container designs will not be specified in this document, although the requirements and considerations for adequate container design are addressed here. Engineering designs will be finalized in conjunction with LANL.

\subsubsection{Container Requirements}

The high chloride concentration characteristic of WIPP brines and Brine A is corrosive to steels. Even stainless steels such as SS316 experience a high rate of stress corrosion when exposed to these brines at elevated temperatures (Braithwaite and Molecke, 1980; Molecke et al., 1993). Insofar as the test containers may contain brine for many years, ferrous alloys are not recommended for use in STTP container construction. Inert liners or coatings that can be

\footnotetext{
'G. Choppin (Florida State University) estimates that these ligands (in addition to hydroxide and carbonate) have the highest potential for increasing actinide solubilities in brine in contact with TRU waste (Brush, 1990). This list is based on assumptions of quantities of ligands in the inventory and their solubilities in brine. If insoluble ligands are present in significant amounts, and if they emulsify during agitation, they will have to be extracted from the leachate samples using organic solvents.
} 
scratched or abraded by waste items during agitation will not adequately protect the surface of a steel container. It is therefore recommended that the drum-scale containers be fabricated from an inert metal such as a $\mathrm{Ti}$ alloy. Liter-scale containers may be fabricated from standard nonferrous, corrosion-resistant materials such as Inconel, Hastelloy, $\mathrm{Ti}, \mathrm{Ni}$, or $\mathrm{Zr}$.

For the waste types used in the drum-scale tests, increased test container size will tend to "average out" waste inhomogeneity, leading to better agreement between replicates and thus less uncertainty in the actinide concentrations for a given waste type. The selection of a container size, which will be determined by LANL, will depend on factors such as container availability, overpack requirements, and compatibility with radionuclide-assay equipment. The drum-scale test containers are required to use the contents of an integer number of waste drums (Section 3.1). This requirement can be met by using a test container that will accommodate the contents of a 55-gal. drum, backfill material (as required), and approximately $40 \mathrm{~L}$ of brine present as iree liquid. It is estimated that a test container capacity of $65 \mathrm{~L}$ will be sufficient. While container volumes much larger than this are suitable technically, the larger brine volume thereby required increases any problems associated with brine disposal during test decommissioning.

Containers on the order of 2-5 L volume can bc used for the liter-scale tests. Smaller containers will not accommodate sufficient free brine volume to permit the sampling schedule described in Section 3.4.2.

\subsubsection{Mixing and Sampling Requirements}

To allow all of the solid phase material the opportunity to react with the brine and render the results from leachate sampling more meaningful, it is essential that both the liquid and solid contents of the test containers are thoroughly mixed. Several design concepts involving external agitation of the test containers may provide reliable mixing. These include shaking or oscillating the drums using a device similar to a large paint shaker or turning drums that incorporate curved ribs fixed to the inside walls on a rotary mill or tumbler.

Leachate samples will be withdrawn from ports on the ends or sides of the containers. Each test vessel should have two sampling ports located on opposite sides of the container or dip tubes of different lengths connected to the lid. This will allow leachate samples of at least $50 \mathrm{~mL}$ to be withdrawn so that air cannot contact the sample or intrude into the test vessel, and dissolved gases cannot escape from the leachate. The efficacy of mixing will be tested by sampling from both ports and comparing the compositions of the two samples. The frequency of dual sampling will be determined for each container based on previous results, though in general, dual sampling will probably not be required every time leachate is withdrawn.

Prior to test initiation, the efficacy of agitation in the drum-scale containers will be tested in a prototype that will contain nonradioactive combustible waste and a bentonite backfill material. A neodymium (III) salt tracer will be added by soaking a cloth with a solution of the 
tracer and adding the cloth to the mock waste. At least one sample will be taken after each agitation cycle from each of two sampling ports located at opposite ends of the prototype vessel. One port must be located along the inside of the drum wall; the other located along the longitudinal axis of the drum. The criterion for acceptable agitation is defined here as less than $10 \%$ difference in tracer concentration in samples taken from different ports. The prototype will be tested to determine the number of agitation cycles required to meet this requirement.

Container agitation must be stopped between 18 and 32 hours prior to sampling. Ambient-pressure experiments will be sampled semimonthly during the first three months of the experiment and bimonthly thereafter. High-pressure experiments will be sampled every four months, due to the lower volume of free brine and the greater difficulty of sample collection in these tests. Any gas pressure exceeding 3 psig will be vented prior to sample collection from the ambient pressure tests. Liquid must be collected from the high-pressure vessels without significant loss of gas pressure from the container and filtered under pressure. In all tests, sampling equipment must be preconditioned so that no significant quantities of radionuclides are lost through sorption.

Test containers must be able to accept additional liquid or suspended actinide spikant during operation if leachate analyses indicate that the concentrations of one or more actinides in the brine have become limited by actinide inventory.

\subsubsection{Temperature Monitoring and Control}

Temperature of the test environment should be held at $30^{\circ} \mathrm{C}$ with a maximum deviation of $\pm 5^{\circ} \mathrm{C}$. This range is specified so that the chemistry and biology of the waste-brine system will be WIPP repository relevant and will not be unduly perturbed by temperature excursions external to the test vessel. A thermocouple should be installed on each test container to monitor the temperature within the vessel, which may change as a result of microbial activity. Temperature data will be recorded, and it is anticipated that temperature measurement to within $2{ }^{\circ} \mathrm{C}$ will be sufficient.

\subsubsection{Gas Sampling and Relief}

Gas may build up in the test containers as the result of anoxic corrosion of steels, microbial activity, or brine radiolysis. The test containers will allow for periodic sampling of gas for compositional analysis (Section 4.3). All containers will have provisions for venting any gases before the pressure exceeds the normal limits of the container. Excess gas pressure $(>3$ psig) must also be released prior to sampling, and gas samples may be taken concurrently with leachate sampling. Both sampling and venting must take place without introducing air into the vessels. Gas may be vented or sampled into individual traps or into a manifold. Both drum- and liter-scale vessels will require fixtures for venting and sampling, with the exception of the highpressure liter-scale vessels, which do not require gas sampling ports. 


\subsubsection{Leak-Tightness}

The maximum rate at which radioactive brine may be leaked from the test containers during the experimental phase is an important operational concern. For the purposes of calculating the highest acceptable brine-leak rate, it may be tentatively assumed that the maximum specific activity of the leachate will be $200 \mu \mathrm{Ci} / \mathrm{mL}$.

It is essential to the success of the STTP that the chemical conditions within the test container resemble those in the disposal rooms during the post-disposal phase. This requires that atmospheric oxygen be excluded from the containers to the extent possible because even trace quantities of oxygen can interfere with anaerobic microbial metabolism and anoxic steel corrosion and oxidize Pu from the trivalent to the tetravalent oxidation state. However, it is also recognized that it is impossible in a finite amount of time to ascertain that the $\mathrm{O}_{2}$ ingress rate in a container is "zero." Also, very small quantities of oxygen leaked into the containers will probably have little effect on the system as long as these quantities are less than those generated by radiolysis, or are insufficient to inhibit anoxic corrosion or anaerobic activity. Unfortunately, the maximum $\mathrm{O}_{2}$ concentrations tolerated by these processes are unknown, and it will be very difficult to derive these data through experiment. However, it is apparent that an $\mathrm{O}_{2}$ ingress rate that does not exceed the rate of production of oxygen (or other oxidizing species) through radiolysis will not bias the experimental conditions. From data on radiolysis of Brine $A$ solutions containing ${ }^{234} \mathrm{Pu}$ (Reed et al., 1993), it is calculated that radiolysis from a solution of $10^{.7} \mathrm{~mol} / \mathrm{L}$ ${ }^{234} \mathrm{Pu}$ in brine in a $250 \mathrm{~L}$ container will generate ox.dizing species equivalent to $1.3 \mathrm{ppm} \mathrm{O}_{2}$ per year. While data required to make meaningful estimates of radiolytic production from actinidecontaining solids are not available, it is observed that gas production from undissolved alpha sources is much less efficient than from dissolved sources. It is concluded that an $\mathrm{O}_{2}$ ingress rate yielding no more than $2 \mathrm{ppm}$ oxygen per year in an empty container will aid in rendering the data from the STTP experiments defensible and is therefore a goal of the project. It is required that no drum- or liter-scale container has a calculated or measured $\mathrm{O}_{2}$ ingress rate exceeding 20 ppın $\mathrm{O}_{2}$ per year.

It should be noted that due to their smaller size, the allowable leak rate (in $\mathrm{mL} / \mathrm{s}$ ) of the liter-scale containers will be approximately 100 times less than that of the drum-scale containers. All containers must be leak-checked prior to use. If helium is used to leak-check the containers, a correlation between $\mathrm{O}_{2}$ ingress rate and $\mathrm{He}$ leak rate must be established either by calculation or by experiment using prototype containers.

This assumption is based on a maximum $\mathrm{Pu}$ and $\mathrm{Am}$ concentrations of $2 \times 10^{-4} \mathrm{M}$ in the brine, and alpha-curie contents of $0.07 \mathrm{Ci} / \mathrm{g}$ and $3.5 \mathrm{Ci} / \mathrm{g}$ for weapons-grade $\mathrm{Pu}$ and ${ }^{241} \mathrm{Am}$, respectively (Zerwekh, 1979). 


\subsubsection{High-Pressure Experiments}

The $\mathrm{CO}_{2}$ overpressure to be used in these experiments is 60 bar. It is assumed that commercially available Hastelloy autoclaves will be suitable for these experiments with minor modification. Leachate must be withdrawn and filtered under pressure, but filter(s) may be made a part of the sampling apparatus. The pressure drop across the filters should not be great enough to cause them to rupture. Pressure must be held constant during sampling using an external source of $\mathrm{CO}_{2}$. Only one leachate sampling port is required on these containers. Leachate will be stored at ambient pressure. Particle sizes will not be analyzed; instead, the leachate will be digested to bring all precipitated and suspended material into solution prior to elemental analysis. These containers will not be resupplied with fresh brine during the tests; therefore, it is anticipated that fewer than ten brine samples will be taken from these containers. Gas samples will not be taken from the high-pressure experiments. 


\subsection{TEST OPERATION}

The source-term tests will be operated in accordance with the quality requirements of DOE Order 5700.6C, with the applicable supplemental requirements of NQA-1, or with future revisions of these standards. The WIPP QAPP pertains to the source-term tests because data from these tests will ultimately support WIPP Performance Assessment.

\subsection{Leachate Sampling}

A liquid leachate sample of approximately $50 \mathrm{~mL}$ volume will be periodically drawn from each test container. The leachate sample will be drawn through a $1 \mu \mathrm{m}$ filter. All dissolved species and suspended colloidal particles in the liquid sample (defined here as having an effective diameter of less than $1 \mu \mathrm{m}$ ) will pass through this filter. Although filtration should be performed as soon as possible after sampling, no experimental constraint requires that the filter(s) be a part of the sampling apparatus. Particulate materials collected on the $1 \mu \mathrm{m}$ filters will not be analyzed. The filtered samples must be collected in containers treated to minimize sorption of the actinide ions onto the container walls. It is essential that the samples be withdrawn so that contact with air is prevented and that they be stored in airtight vessels to prevent both oxidation of metal ions in the leachate and loss of dissolved gases in the brine prior to analysis. In addition, exposure of the sample to light should be minimized. Liter-scale containers may require periodic reinjection of WIPP brine/Brine A mixture to prevent depleting the test vessel of brine.

The stability of the leachate samples over time is unknown. Results from aging studies on standards used in analytical method development and on the leachate samples taken from the initial experiments will define the maximum allowable interval between sampling and leachate analysis.

Relevant sampling data to be recorded include date and time of sampling, volume drawn, and other observations, including difficulties encountered during the procedure. It is assumed that the test facility will withdraw leachate samples quarterly, although an accelerated sampling schedule will be followed during the first few months of the experiments. It is assumed that 16 samples will be withdrawn from each test container, on average, over the lifetime of the experiments.

\subsection{Leachate Analysis}

The criteria for the techniques and requirements of the analyses used to characterize the leachate samples are defined in this section. The following analyses and procedures will be performed on all samples, generally in the order given here: 
1. $\mathrm{pH}$ measurement. This is complicated by the high ionic strength of the brine, which renders unequivocal hydrogen ion activity measurements difficult. It is desired that $\mathrm{pH}$ actually be determined as $\mathrm{pcH}\left(-\log _{10}\left[\mathrm{H}^{+}\right]\right.$, as opposed to $\left.-\log _{10} a \mathrm{H}^{+}\right)$and that measurements will be accurate to within $0.2 \mathrm{pcH}$ units. The technique required uses a combination glass electrode calibrated using spectrophotometric methods (Byrne, 1987; Felmy et al., 1989). SNL will provide a procedure for the execution of the $\mathrm{pcH}$ measurement.

2. Oxidation potential (Eh). It is recognized that this measurement will not definitively determine the distribution of oxidation states within the samples, due to kinetic barriers to reduction of actinide oxy-cations (Lindberg and Runnels, 1984). However, anomalies in Eh among leachate samples from the same waste types will indicate whether a full determination of the oxidation states of $\mathrm{Pu}$ should be performed for these samples. Eh measurements may be estimated using a saturated calomel (SCE) reference electrode with a platinum working electrode or from relative concentrations of species in redox couples such as $\mathrm{Fe}^{+3} / \mathrm{Fe}^{+2}$.

3. Filtration: half of the leachate sample will be sequentially filtered to remove all suspended material. One possible series of pore sizes would be $1 \mu \mathrm{m} \rightarrow 450 \mathrm{~nm} \rightarrow 220$ $\mathrm{nm} \rightarrow 100 \mathrm{~nm} \rightarrow 50 \mathrm{~nm} \rightarrow 20 \mathrm{~nm}$. Some pre-test experimentation may be necessary to determine the ideal pore size for the smallest membrane filter. Both the volumes of the original sample and the filtrate should be known to within $\pm 2 \%$. In subsequent analyses, coarsely filtered leachate refers to brine that has passed a $1 \mu \mathrm{m}$ filter, and finely filtered leachate denotes brine that has passed through a $20 \mathrm{~nm}$ filter.

4. Rough concentration measurement. Liquid alpha-scintillation or energy-dispersive $\mathbf{x}$-ray fluorescence (ED XRF) can be used to approximately measure relative actinide concentrations in the filtered and unfiltered leachate portions. This will determine the workup procedure to be followed prior to using ICP-MS (step 7) and to aid in selecting standards for same. The purpose of measuring concentrations in both portions is to establish whether significant activity in the brine is actually in suspension. If activities are similar in the coarsely and finely filtered leachates, actinides are probably not borne by colloids in the sample and particle size analysis (step 6) is unnecessary. It should be noted that high precision actinide determination at low concentrations in the unfiltered leachate using LSC will be difficult if actinide-carrying colloids are present. If it is apparent that actinide concentrations are significantly higher in the unfiltered leachate, the colloids will be dissolved and the actinide concentrations remeasured to give values for total liquid phase and colloidally bound actinides (step 7). Alternatively, the filters used in step 4 may be analyzed for actinides and possibly their colloid host matrices, using $\mathrm{XRF}$ or a related technique.

'A description of oxidation potential measurement in saline waters is given in Breck, 1974. 
5. Particle size analysis. The unfiltered leachate may contain suspended colloidal particles ranging in size from $1 \mu \mathrm{m}$ or larger (resulting from exfoliated clays) to $1-2 \mathrm{~nm}$ (polynuclear plutonium species). It will be necessary to measure dispersion of particle size in the leachate, that is, to determine the fraction of suspended particles within a given size range. Light scattering measurements or sequential filtration should be adequate for dispersion measurements in the size regime expected for exfoliated clay particles. Scanning electron microscopy (SEM) or transmission electron microscopy (TEM), in combination with a microanalysis method such as energy-dispersive $\mathbf{x}$-ray, will be required to characterize the smaller colloids.

6. ICP-ES and/or ICP-MS (Inductively coupled plasma emission spectroscopy, mass spectrometry). ICP-MS will be used to measure the concentrations of the actinide elements $\mathrm{Th}, \mathrm{U}, \mathrm{Np}, \mathrm{Pu}, \mathrm{Am}$, and $\mathrm{Nd}$. Detection limits for all actinides should be at least $10^{-10} \mathrm{M}$ with $100 \%$ precision or better at this concentration and $10 \%$ precision at $10^{-9} \mathrm{M}$ and higher.

7. Flame or furnace atomic absorption spectrophotometry (AAS), to determine $\mathrm{Fe}, \mathrm{Pb}, \mathrm{Al}$, $\mathrm{Mg}$, and $\mathrm{Ca}$. These elements may be determined using ICP-MS (except for $\mathrm{Fe}$ and $\mathrm{Ca}$, which suffer from poor detection limits due to isobaric matrix interferents) if convenience dictates. If no AAS is available, ICP-ES or ISE may be used for determining $\mathrm{Fe}$ and $\mathrm{Ca}$. Detection at $1 \mathrm{ppm}$ is desired.

8. Ion chromatography, to measure concentrations of free fluoride, nitrate, phosphate, sulfate, and carbonate anions in the portion of the sample passed through the smallest membrane filter.

9. Total inorganic carbon (TIC) analysis. This will determine both free and complexed carbonate ion concentrations in the filtered leachate.

10. Total organic carbon (TOC) analysis on both the filtered and unfiltered leachate. This will indicate whether significant quantities of organic material are suspended in the unfiltered leachate, either as colloids or as emulsified liquids. If this is the case, and if actinide concentrations are substantially greater in the unfiltered leachate, extraction may be indicated to reveal whether the actinides are associated with the suspended organics.

11. Analysis of dissolved organics: the organic components that need to be characterized are those ligands that are part of the original waste matrix, those used as spikants, and those

This requirement is derived from the minimum Pu and Am concentrations yielding a normalized release fraction of $10^{-2}$ for that element, assuming a double borehole (E1E2) intrusion with no retardation in the Culebra. This requirement is extended to $\mathrm{Th}, \mathrm{U}$, and $\mathrm{Np}$ as well because they serve as oxidation state analogs of Pu. 
produced by microbial degradation of cellulose. These ligands include acetamide, acetate, ascorbate, citrate, bis(2-ethylhexyl) phosphoric acid (DHP), EDTA, 2-hydroxybutyrate, 8-hydroxyquinoline, lactate, oxalate, 1,10 phenanthroline, thenoyltrifluoroacetonate (TTA), tartrate, and thiocyanate. This list may be expanded in the Test Plan to include other ligands produced by degradation of cellulose. Analysis should reflect the total quantity of these ligands in solution, both complexed and uncomplexed, although it is not necessary to differentiate between these. Ion chromatography and high-performance liquid chromatography (HPLC) may be appropriate techniques, depending on whether a given analyte is analyzed as a charged or neutral species. Required precision levels and detection limits will be determined in the course of analytical method development, although $\pm 20 \%$ and $1 \mathrm{ppm}$ are considered target values. Only the filtered leachate (leachate that has passed the smallest membrane filter used for workup) will be analyzed.

Unusual results from the preceding analyses may require an extended workup of the leachate, at the discretion of the principal investigator or the lead analytical chemist. These investigations include:

12. Speciation studies. An unusual solution potential (Eh) measurement or abnormally high $\mathrm{Pu}$ concentrations may warrant a detailed breakdown of the distribution of dissolved $\mathrm{Pu}$ among its four expected oxidation states (III, IV, V, and VI). Depending on the Pu concentration in the solution, either spectrophotometry (Stumpe et al., 1984) or extraction/coprecipitation (Nitsche et al., 1988; Kobashi et al., 1988) may prove to be most effective, although it is most likely that only samples sufficiently concentrated in $\mathrm{Pu}$ to allow spectrophotometric determination $\left(>10^{-7} \mathrm{M}\right)$ will be considered for this analysis. High $\mathrm{Pu}$ concentrations may also indicate complexation or chelation by either organic or inorganic ligands. If these processes cannot be adequately identified in analyses 8 through 11 (above), it will be desirable to attempt to measure the proportions of free and complexed Pu in solution. Photoacoustic spectroscopy may be useful, but prior analytical methods development will be required.

13. Characterization of microorganisms in leachate. Unusually high rates of gas production suggestive of microbial activity (e.g., generation of $\mathrm{CO}_{2}, \mathrm{CH}_{4}, \mathrm{H}_{2} \mathrm{~S}$, etc.) will indicate culturing a sample of coarsely filtered leachate and measuring the concentration of colony-forming units (CFUs) in the brine. This analysis will reveal if signs of microbial activity are associated with significant multiplication of halophilic and halotolerant bacteria introduced into the test containers via the brine collected from the WIPP underground (section 2.4). If possible, both the concentration of CFUs and their taxonomic classification should be determined. A qualified microbiologist trained in the handling of alpha-emitting materials should perform the bacterial culturing and counting procedures. Descriptions of these procedures will be provided by SNL. 


\subsection{Gas Sampling and Analysis}

The STTP experiments will sample and analyze the gas to identify major light gas constituents and their relative proportions over time. Information on gas composition is critical to the experiments because it will aid in identifying anoxic corrosion and brine radiolysis and may indicate the type and extent of microbial processes taking place. Gas data will thus be a principal indicator of effective Eh within the test vessels. Test containers will require a pressurerelief mechanism, a particulate filter that will prevent release of radioactive material, and either a carbon composite filter (or some other type of gas scrubber) for sorbing VOCs, or a system for venting these gases in a controlled fashion.

All tests require sampling of the headspace or effluent gas to determine composition. Gases of interest include $\mathrm{H}_{2}, \mathrm{O}_{2}, \mathrm{CH}_{4}, \mathrm{CO}, \mathrm{CO}_{2}, \mathrm{H}_{2} \mathrm{~S}$, and $\mathrm{N}_{2}$, because these gases signal such events as anoxic corrosion, microbial activity, radiolysis, and container leakage. One possible sampling method requires drawing gas through the particulate filter into an evacuated stainless steel container and measuring gas composition using gas chromatography (GC) with mass spectrometry (MS) or other techniques. Gas composition can also be measured in "real-time" by drawing gas from a vent trap directly into a GC-MS apparatus, though it may be difficult to sample while agitating the test vessels, and agitation may be interrupted to permit sampling. In any case, gas will be sampled at a point in the system upstream of the carbon composite filter. It is anticipated that gas will initially be sampled every three weeks, then monthly after the first 12 weeks of the experiment.

\subsection{Other Operational Considerations}

Data from the brine leachate analyses must be available for rapid review by both the SNL Actinide Source-Term Program staff and the lead analyst at LANL to permit possible changes in test sampling schedules, to help evaluate potential problems, and to provide timely, periodic input to support model evaluation and WIPP Performance Assessment.

The analytical procedures described above have not been fully developed for use in high ionic strength solutions (such as the brine leachate from these tests) and will require preliminary investigation to determine their applicability to leachate characterization. The complexity of the leachate matrix introduces a significant degree of unpredictability into its chemistry, and certain procedures listed in this section may require modification by the laboratory conducting the analyses or a future redefinition of analytical criteria. Full development of analytical methods must therefore precede the initiation of both the drum- and liter-scale tests.

Following analysis, any unused leachate sample will be archived at $30^{\circ} \mathrm{C}$ for possible additional work. Residual leachate samples will be retained for a minimum of one year at the analytical laboratory location or until released by the SNL principal investigator and SNL WIPP QA. It is assumed that the residual leachate will be disposed of by the analyzing laboratory after release. 
The STTP tests are anticipated to continue for approximately 2-3 years, though individual tests may be extended at the discretion of the SNL principal investigator or his/her designee. After leachate analyses indicate that the actinide concentrations in individual experiments have reached a steady state, tests may be decommissioned or subjected to settling experiments, again at the principal investigator's discretion. These settling experiments will monitor colloidal concentrations in unagitated containers as a function of time. After brine has been removed from the containers as part of decommissioning, solid samples may be recovered for post-test analysis to determine how actinides are distributed within the solid phases present. If possible, the solids responsible for controlling actinide solubility will be identified. LANL.

Specific requirements for decommissioning and decontamination will be defined by 


\subsection{REFERENCES}

Baes, C.F., Jr., and R.E. Mesmer. 1976. The Hydrolysis of Cations. New York, NY: John Wiley \& Sons. 186.

Braithwaite, J.W., and M.A. Molecke. 1980. "Nuclear Waste Canister Corrosion Studies Pertinent to Geologic Isolation," Nuclear and Chemical Waste Management. SAND791935J. Vol. 1, no. 1, 37-50.

Breck, W.G. 1974. "Redox Levels in the Sea," The Sea - Ideas and Observations on Progress in the Study of the Seas. Volume 5: Marine Chemistry. Ed. E.D. Goldberg. New York, NY: John Wiley and Sons. Vol. 5, 153-179.

Brush, L.H. 1990. Test Plan for Laboratory and Modeling Studies of Repository and Radionuclide Chemistry for the Waste Isolation Pilot Plant. SAND90-0266. Albuquerque, NM: Sandia National Laboratories.

Byrne, R.H. 1987. "Standardization of Standard Buffers by Visible Spectrometry," Analytical Chemistry. Vol. 59, no. 10, 1479-1481.

Caldwell, D.E., R.C. Hallet, M.A. Molecke, E. Martinez, and B.J. Barnhart. 1988. Rates of $\mathrm{CO}_{2}$ Production from the Microbial Degradation of Transuranic Wastes Under Simulated Geologic Isolation Condirions. SAND87-7170. Albuquerque, NM: Sandia National Laboratories.

Felmy, A.R., D. Rai, J.A. Schramke, and J.L. Ryan. 1989. "The Solubility of Plutonium Hydroxide in Dilute Solution and in High-Ionic-Strength Chloride Brines," Radiochimica Acta. Vol. 48, no. 1/2, 29-35.

Francis, A.J. 1990. "Microbial Dissolution and Stabilization of Toxic Metals and Radionuclides in Mixed Wastes," Experientia. Vol. 46, no. 8, 840-851.

Francis, A.J., C.J. Dodge, J.B. Gillow, and J.E. Cline. 1991. "Microbial Transformations of Uranium in Wastes," Radiochimica Acta. Vol. 52-53, pt. 2, 311-316.

Helton, J.C., J.W. Garner, R.P. Rechard, D.K. Rudeen, and P.N. Swift. 1992. Preliminary Comparison with 40 CFR Part 191, Subpart B for the Waste Isolation Pilot Plant, December 1991. Volume 4: Uncertainty and Sensitivity Analysis Results. SAND910893/4. Albuquerque, NM: Sandia National Laboratories. Chapter 5.

Kobashi, A., G.R. Choppin, and J.W. Morse. 1988. "A Study of Techniques for Separating Plutonium in Different Oxidation States," Radiochimica Acta. Vol. 43, 211-215. 
Lindberg, R.D., and D.D. Runnels. 1984. "Ground Water Redox Reactions: An Analysis of Equilibrium State Applied to Eh Measurements and Geochemical Modeling," Science. Vol. 225 , no. $4665,925-927$.

Marietta, M.G., S.G. Bertram-Howery, D.R. Anderson, K.F. Brinster, R.V. Guzowski, H. Iuzzolino, and R.P. Rechard. 1989. Performance Assessment Methodology Demonstration: Methodology Development for Evaluating Compliance with EPA 40 CFR 191, Subpart B, for the Waste Isolation Pilot Plant. SAND89-2027. Albuquerque, NM: Sandia National Laboratories.

Molecke, M.A. 1983. A Comparison of Brines Relevant to Nuclear Waste Experimentation. SAND83-0516. Albuquerque, NM: Sandia National Laboratories.

Molecke, M.A., N.R. Sorenson, J.R. Harbour, and D.M. Ferrara. 1993. "Post-Test Evaluations of Waste Isolation Pilot Plant - Savannah River Simulated Defense HLW Canisters and Waste Form," High Level Radioactive Waste Management, Proceedings of the Fourth Annual International Conference, Las Vegas, NV, April 26-30, 1993. SAND91-2038C. La Grange Park, IL: American Nuclear Society, Inc.; New York, NY: American Society of Civil Engineers. Vol. 1, 558-562.

Nitsche, H., S.C. Lee, and R.C. Gatti. 1988. "Determination of Plutonium Oxidation States at Trace Levels Pertinent to Nuclear Waste Disposal," Journal of Radioanalytical and Nuclear Chemistry, Articles. Vol. 124, no. 1, 171-185.

Nowak, E.J. 1984. "Diffusion of Colloids and Other Waste Species in Brine-Saturated Backfill Materials," Scientific Basis for Nuclear Waste Management VII, Materials Research Society Symposia Proceedings, Boston, MA, November 14-17, 1983. Ed. G.L. McVay. SAND83-1343C. New York, NY: North-Holland. Vol. 26, 59-68.

Ockenden, D.W., and G.A. Welch. 1956. "The Preparation and Properties of Some Plutonium Compounds. Part V. Colloidal Quadrivalent Plutonium," Journal of the Chemical Society. Part III, 3358-3363.

Pitzer, K.S., ed. 1991. Activity Coefficients in Electrolyte Solutions. 2nd ed. Boca Raton, FL: CRC Press.

Plummer, L.N., D.L. Parkhurst, G.W. Fleming, and S.A. Dunkle. 1988. A Computer Program Incorporating Pitzer's Equations for Calculation of Geochemical Reactions in Brines. Water-Resources Investigations 88-4153. Denver, CO: U.S. Geological Survey. 
Reed, D.T., S. Okajima, L.H. Brush, and M.A. Molecke. 1993. "Radinlytically-Induced Gas Production in Plutonium-Spiked WIPP Brine," Scientific Basis for Nuclear Waste Management XVI, Materials Research Society Symposium Proceedings, Boston, MA, November 30-December 4, 1992 . Eds. C.G. Interrante and R.T. Pabalan. SAND927283C. Pittsburgh, PA: Materials Research Society. Vol. 294, 431-438.

Roy, R.N., K.M. Vogel, C.E. Good, W.B. Davis, L.N. Roy, D.A. Johnson, A.R. Felmy, and K.S. Pitzer. 1992. "Activity Coefficients in Electrolyte Mixtures: $\mathrm{HCl}+\mathrm{ThCl}_{4}+$ $\mathrm{H}_{2} \mathrm{O}$ for 5-55 ${ }^{\circ} \mathrm{C}, "$ Journal of Physical Chemistry. Vol. 96, no. 26, 11065-11072.

Silver, G.L. 1971. "Potential-pH Diagram for Plutonium," Radiochemistry/Radioanalysis Letters. Vol. 7, no. 1, 1-5.

Solache-Rios, M., and G.R. Choppin. 1991. Determination of the pcH in Highly Saline Waters Using Cresol Red. SAND91-7068. Albuquerque, NM: Sandia National Laboratories.

Stumpe, R., J.I. Kim, W. Schrepp, and H. Walther. 1984. "Speciation of Actinide Ions in Aqueous Solution by Laser-Induced Pulsed Photoacoustic Spectroscopy," Applied Physics B. Vol. 34, no. 4, 203-206.

Trauth, K.M., R.P. Rechard, and S.C. Hora. 1991. "Expert Judgment as Input to Waste Isolation Pilot Plant Performance-Assessment Calculations: Probability Distributions of Significant System Parameters," Mixed Waste: Proceedings of the First International Symposium, Baltimore, MD, August 26-29, 1991. Eds. A.A. Moghissi and G. A. Benda. SAND91-0625C. Baltimore, MD: Environmental Health and Safety, University of Maryland. 4.3.1 - 4.3.9.

U.S. Environmental Protection Agency (US EPA). 1985. "40 CFR 191: Environmental Standards for the Management and Disposal of Spent Nuclear Fuel, High-Level and Transuranic Radioactive Wastes," Federal Register. Vol. 50, no. 182, 38066-38099.

Westinghouse Electric Corp. 1989. TRUPACT-II Content Codes (TRUCON). DOE-WIPP 89-004, Rev. 3. Carlsbad, NM: Westinghouse Electric Corporation.

WIPP Performance Assessment Division (WPD). 1991a. Preliminary Comparison with 40 CFR Part 191, Subpart B for the Waste Isolation Pilot Plant, December 1991. Volume 1: Methodology and Results. SAND91-0893/1. Albuquerque, NM: Sandia National Laboratories.

WIPP Performance Assessment Division (WPD). 1991b. Preliminary Comparison with 40 CFR Part 191, Subpart B for the Waste Isolation Pilot Plant, December 1991. Volume 3: Reference Data. Eds. R.P. Rechard, A.C. Peterson, J.D. Schreiber, H.J. Iuzzolino, M.S. Tierney, and J.S. Sandha. SAND91-0893/3. Albuquerque, NM: Sandia National Laboratories. 
Wolery, T.J. 1979. Calculation of Chemical Equilibrium Between Aqueous Solution and Minerals: The EQ3/6 Software Package. UCRL-52658. Livermore, CA: Lawrence Livermore Laboratory.

Zerwekh, A. 1979. Gas Generation from R adiolytic Attack of TRU-Contaminated Hydrogenous Waste. LA-7674-MS. Los Alamos, NM: Los Alamos National Laboratory. 
APPENDIX A:

STTP Test Matrix

A-1 
Appendix A: STTP Teat Matrix

Expt. no.

TRUCON

description

backfill

code

Drum-scale tests:

D1, D2, D3

$116 / 216$

combustibles

none

D4, D5, D6

$116 / 216$

combustibles

bentonite

D7, D8, D9

$116 / 216$

combustibles, enriched

none

D10, DI1, D12 116/216+111/211

combustibles and sludge

none

D13, D14, D15 117/217

metals

none

Total: 15 drum-scale tests

Liter-scale tests:

\begin{tabular}{|c|c|c|c|}
\hline L1, L2, L3 & $111 / 211$ & dewatered aqueous inorganic sludge & none \\
\hline L4, LS, L6 & $111 / 211$ & dewatered inorganic sludge $w / \mathrm{CO}_{2}^{+}$ & none \\
\hline L7, L8, L9 & $111 / 211$ & inorganic sludge, no iron & none \\
\hline L10, LI1, L12 & $111 / 211$ & sludge, no iron, ${ }^{241} \mathrm{Am}$ spiked & none \\
\hline L13, L14, L15 & $112 / 212$ & absorbed organic liquids & none \\
\hline L16, L17, L18 & $113 / 213$ & absorbed aqueous lab waste & none \\
\hline L19, L20, L21 & $114 / 214$ & cemented inorganic sludge & none \\
\hline L22, L23, L.24 & $126 / 216$ & cemented organic sludge & none \\
\hline L25, L26, L27 & 124214 & pyrochemical salt waste & none \\
\hline L28, L29, L30 & $124 / 214$ & pyrochemical salt waste $\mathrm{w} / \mathrm{CO}_{2}{ }^{+}$ & none \\
\hline L31, L.32, L33 & $124 / 214$ & pyrochemical salt waste & bentonite \\
\hline L34, L35, L36 & $124 / 214$ & pyrochemical salt, no iron & none \\
\hline L37, L38, L39 & $124 / 214$ & pyrochemical salt, no iron, ${ }^{241}$ Am spiked & none \\
\hline
\end{tabular}

Total: 39 liter-scale tests

${ }^{+} \mathrm{CO}_{2}=60$ bar $\mathrm{CO}_{2}$ overpressure. 
APPENDIX B:

Effect of Increased $\mathrm{CO}_{2}$ Pressure on Brine Chemiatry

B-1 


\section{Appendlx B: Effect of Increased $\mathrm{CO}_{2}$ Pressure on Brine Chemistry}

Date: $\quad$ May 20, 1993

To:

E. J. Nowak, 6345; and E. D. Gorham, 6119

From:

Craig F. Novak, 6119

Subject:

Modeling of the Chemical Alteration of SPC Brine as a Function of $\mathrm{CO}_{2}(\mathrm{~g})$ Fugacity, and Modeling the Fugacity of Pure $\mathrm{CO}_{2}(\mathrm{~g})$ as a Function of Pressure 


\section{Sandia National Laboratories}

dale: 20 May 1993

Albuquerque, New Mexico 87185

to: E.J. Nowak, 6345, and E.D. Gorham, 6119

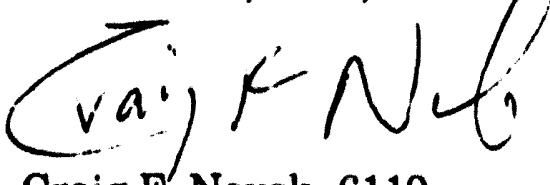

from: Craig F. Novak, 6119

subject: Modeling of the Chemical Alteration of SPC Brine as a Function of $\mathrm{CO}_{2}(\mathrm{~g})$ Fugacity, and Modeling the Fugacity of $\mathrm{Pure}^{\mathrm{CO}_{2}}(\mathrm{~g})$ as a Function of Pressure

\section{Summary}

This memorandum presents results from two modeling studies examining the compositional changes of a synthetic Salado brine in response to contact with $\mathrm{CO}_{2}(\mathrm{~g})$ at various pressures. The first model examines changes in the chemical composition of the brine as a function of $\mathrm{CO}_{2}(\mathrm{~g})$ fugacity, which is a thermodynamic function describing the tendency of $\mathrm{CO}_{2}(\mathrm{~g})$ to dissolve. The second model examines the fugacity of pure $\mathrm{CO}_{2}(\mathrm{~g})$ as a function of pressure. For a pure $\mathrm{CO}_{2}(\mathrm{~g})$ phase at less than 200 atm pressure, the results suggest that only the $\mathrm{pH}$ and dissolved $\mathrm{CO}_{2}$ content of the brine will change in response to pressure changes. In addition, the models indicate that the $\mathrm{CO}_{2}(\mathrm{~g})$ fugacity is approximately a linear function of pressure with a relatively large slope through $\sim 65 \mathrm{~atm}$. At greater pressures, the $\mathrm{CO}_{2}(\mathrm{~g})$ fugacity remains a linear function but with a much smaller slope.

This work supports the Laboratory and Modeling portions of the Actinide Source Term Test Program (ASTP) by delineating ranges of dissolved $\mathrm{CO}_{2}$ concentrations that could occur in the WIPP underground, and thus may need to be examined in the laboratory. Moreover, these results could have implications for choosing operating conditions for the proposed liter-scale experiments with high $\mathrm{CO}_{2}(\mathrm{~g})$ pressures that are part of the Actinide Source-Term Waste Test Program (STTP).

\section{Introduction}

Microbial degradation and radiolysis of WIPP wastes may generate gases such as $\mathrm{CO}_{2}(\mathrm{~g}), \mathrm{H}_{2}(\mathrm{~g})$, and $\mathrm{H}_{2} \mathrm{~S}(\mathrm{~g})$ in sufficient quantities to reach high pressures in the disposal rooms (Brush, 1990). The $\mathrm{CO}_{2}(\mathrm{~g})$ so generated could dissolve in 
brines that may collect in the WIPP disposal rooms, increasing the brine acidity and the amount of dissolved $\mathrm{CO}_{2}$ available for complexation with actinides. This memorandum uses established, validated chemical models for the brine and gas phases to examine the solubility of carbon dioxide in a synthetic brine. The synthetic brine is intended to mimic the major chemical constituents of brines collected from the Salado Formation, and has thus been named Salado Primary Constituent Brine, or SPC Brine ${ }^{\dagger}$.

Two separate models are used to address $\mathrm{CO}_{2}(\mathrm{~g})$ solubility in SPC Brine. The first model considers changes in the chemical composition of the brine as a function of the $\mathrm{CO}_{2}(\mathrm{~g})$ fugacity in equilibrium with the brine. (Fugacity is a thermodynamic function used to describe phase equilibria, and is discussed in more detail below.) The second model considers the gas phase, examining the fugacity of pure $\mathrm{CO}_{2}(\mathrm{~g})$ as a function of the system pressure.

The calculations in this memorandum suggest upper limits for dissolved $\mathrm{CO}_{2}(\mathrm{~g})$ concentrations that need to be considered as part of the WIPP laboratory program to measure actinide solubilities, and provide estimates of the sensitivity of brine composition to $\mathrm{CO}_{2}(\mathrm{~g})$ fugacities. The calculations also suggest ranges of $\mathrm{CO}_{2}(\mathrm{~g})$ pressures that may be used in planned experiments to approximate conditions in WIPP disposal rooms after decommissioning.

\section{Model for Brine Chemistry}

The chemical alteration of SPC Brine under increasing fugacities of carbon dioxide gas was studied using the equilibrium batch calculation option of the FMT code (Novak, 1993; Novak and Sevougian, 1992). The simulations use the validated chemical database of Harvie et al. (1984) with the extension to include boron of Felmy and Weare (1986). The simulations were performed to estimate upper concentration limits for dissolved $\mathrm{CO}_{2}$ that may occur in disposal room brines under high $\mathrm{CO}_{2}(\mathrm{~g})$ pressures. These limits are important for establishing

+ SPC Brine is based on the composition listed as "Brine A" in Table 2.2. of Brush (1990). However, the brine composition listed was not the original Brine A as defined in Table 2 of Molecke (1983), but rather a truncated version containing only the major constituents; $\mathrm{Sr}$, $\mathrm{Li}, \mathrm{Rb}, \mathrm{Sc}, \mathrm{I}$, and $\mathrm{Fe}$ were not included. In an attempt to eliminate possible confusion, the new name Salado Primary Constituent Brine was coined for the purposes of this memorandum and for future work. 
concentration ranges under which to study actinide solubilities. The brine phase was considered to be incompressible in all calculations.

\section{Composition of SPC Brine}

Table 1 presents the composition of SPC Brine. The composition is based on that of the truncated Brine A given in Table 2.2 of Brush (1990). However, the elemental calcium concentration was taken to be $15 \mathrm{mM}$ instead of the $20 \mathrm{mM}$ listed in Brush (1990) because of an oversight in propagation of significant figures when the table was being prepared (Brush, personal communication, 27 March 1992). When this brine was equilibrated at the specified $\mathrm{pH}^{\dagger}$, the model predicted precipitation of approximately $10 \mathrm{mM}$ of magnesite, $\mathrm{MgCO}_{3}(\mathrm{~s})$. This could be the result of the specified $\mathrm{pH}$, the meaning of which is very difficult to interpret in brines (see for example Knauss et al., 1991; Mesmer, 1991; Knauss et al., 1990). However, the effect on total magnesium content is negligible, and the effect on dissolved carbon content is unimportant because of the large source of $\mathrm{CO}_{2}(\mathrm{~g})$ in contact with the brine in further equilibrium calculations.

$\dagger$ interpreted throughout this memorandum to be the negative logarithm of hydrogen ion activity using the "unscaled" activity coefficient convention in the chemical model of Harvie et al. (1984).

Table 1. Equilibrated concentrations in SPC Brine.

\begin{tabular}{|l|c|c|c|}
\hline & $\mathrm{mM}$ & Molality & $\mathrm{mg} /$ liter \\
\hline & & & \\
\hline Sodium & 1830 & 2.00 & 42100 \\
\hline Potassium & 770 & 0.840 & 30100 \\
\hline Magnesium & $1430^{\circ}$ & 1.56 & 34800 \\
\hline Calcium & 15 & 0.0164 & 601 \\
\hline Chlorine & 5350 & 5.83 & 190000 \\
\hline Sulfur & 40 & 0.0436 & 1280 \\
\hline Carbon & $0.161^{\circ}$ & $1.76 \times 10^{-4}$ & 1.93 \\
\hline Boron & 20 & 0.0218 & 216 \\
\hline Bromine & 10 & 0.0109 & 799 \\
\hline Specific Gravity & 1.2 & & \\
\hline pH & 6.5 & & \\
\hline Excess Positive Chargef & & 0.0532 & \\
\hline
\end{tabular}

- Values for magnesium and carbon are both about $10 \mathrm{mM}$ lower than the $15 \mathrm{mM}$ value given by Brush (1990) because of the predicted precipitation of $\sim 10 \mathrm{mM}$ of magnesite, $\mathrm{MgCO}_{3}(\mathrm{~s})$, during the equilibrium calculation.

$\dagger$ When sufficient protons were added to attain the required $\mathrm{pH}$, the listed Excess Positive Charge resulted. 


\section{Expression for $\mathrm{CO}_{2}(\mathrm{~g})$ Fugacity in the Brine Model}

Equilibrium with carbon dioxide was simulated by adding a pure $\mathrm{CO}_{2}(\mathrm{~g})$ phase to the brine system and adjusting the total pressure. Thermodynamically, phase equilibrium is attained when the chemical potential of each species, e.g., $\mathrm{CO}_{2}$, is the same in each phase. The chemical potential of gaseous carbon dioxide, $\mu_{\mathrm{CO}_{2}(\mathrm{~g})}$, is related to its dimensionless free energy of formation, $\mu_{\mathrm{CO}_{2}(\mathrm{~g})}$, and to the $\mathrm{CO}_{2}(\mathrm{~g})$ fugacity, $\mathrm{f}_{\mathrm{CO}_{2}(\mathrm{~g})}$, by

$$
\mu_{\mathrm{CO}_{2}(\mathrm{~g})}=\stackrel{\circ}{\mu_{\mathrm{CO}_{2}(\mathrm{~g})}}+\ln \frac{\mathrm{f}_{\mathrm{CO}_{2}(\mathrm{~g})}}{1 \mathrm{~atm}}
$$

The $\mathrm{CO}_{2}(\mathrm{~g})$ fugacity is given by

$$
\mathrm{f}_{\mathrm{CO}_{2}(\mathrm{~g})}=\phi_{\mathrm{CO}_{2}(\mathrm{~g})} \mathrm{y}_{\mathrm{CO}_{2}(\mathrm{~g})} \mathrm{P}
$$

where $\phi_{\mathrm{CO}_{2}(\mathrm{~g})}$ is the fugacity coefficient, and $\mathrm{y}_{\mathrm{CO}_{2}(\mathrm{~g})}$ is the mole fraction of $\mathrm{CO}_{2}(\mathrm{~g})$ (p. 227, Smith and Van Ness, 1975). The gas model currently implemented within FMT assumes the gas phase is ideal, i.e., that the fugacity coefficient, $\phi_{\mathrm{CO}_{2}(\mathrm{~g})}$, is unity. Thus, the fugacities of gaseous species are approximated as the partial pressure, i.e., the gas mole fraction times total pressure. Because the gas phase was pure $\mathrm{CO}_{2}(\mathrm{~g})$, the carbon dioxide mole fraction was also unity in the simulations. Therefore, the specified total pressure was actually an effective pressure equal to the $\mathrm{CO}_{2}(\mathrm{~g})$ fugacity. The fugacity of pure $\mathrm{CO}_{2}(\mathrm{~g})$ as a function of pressure is considered in the second half of this memorandum.

\section{Brine Model Results: SPC Brine Composition as a Function of $\mathrm{CO}_{2}(\mathrm{~g})$ Fugacity}

Element molalities as a function of $\mathrm{CO}_{2}(\mathrm{~g})$ fugacity are plotted in Figure 1 on both linear and logarithmic fugacity axes. When the $\mathrm{CO}_{2}(\mathrm{~g})$ fugacity is less than about 300 atm, the only element concentration that changes with $\mathrm{f}_{\mathrm{CO}_{2}(\mathrm{~g})}$ is the total inorganic carbon (TIC). All other element molalities are approximately constant. The total element concentrations do not change below this fugacity because there is no mineral dissolution or precipitation, other than small amounts of magnesite at carbon dioxide fugacities less than about 10 atm. However, the model predicts the $\mathrm{pH}$ will decrease by about four units over this fugacity range, as shown in Figure 2, due to $\mathrm{CO}_{2}(\mathrm{~g})$ dissolution and dissociation into $\mathrm{H}^{+}$and $\mathrm{HCO}_{3}^{-}$. Calculated total inorganic carbon dissolved in the brine is about 1.2 molal at $\mathrm{f}_{\mathrm{CO}_{2}(\mathrm{~g})}=100$ atm and about 3.8 molal at $\mathrm{f}_{\mathrm{CO}_{2}(\mathrm{~g})}=320 \mathrm{~atm}$. At 
$\mathrm{CO}_{2}(\mathrm{~g})$ fugacities greater than about $300 \mathrm{~atm}$, the model predicts precipitation of halite, $\mathrm{NaCl}(\mathrm{s})$, and other minerals, as shown in Figure 3. This precipitation causes the decreases in element concentrations seen at large $\mathrm{CO}_{2}(\mathrm{~g})$ fugacities in Figure 1.

\section{Gas Phase Fugacity Model}

The composition of the gas phase that may occur in the WIPP waste room environment after decommissioning is unknown. However, it may be possible to establish approximate limits on $\mathrm{CO}_{2}$ (g) fugacity in these mixtures by assuming a pure $\mathrm{CO}_{2}(\mathrm{~g})$ phase. As given in Equation 2, the $\mathrm{CO}_{2}(\mathrm{~g})$ fugacity is a product of the $\mathrm{CO}_{2}(\mathrm{~g})$ mole fraction, the fugacity coefficient of $\mathrm{CO}_{2}(\mathrm{~g})$, and the system pressure. The effect of mole fraction on fugacity is maximized by considering a pure $\mathrm{CO}_{2}(\mathrm{~g})$ phase, i.e., $\mathrm{y}_{\mathrm{CO}_{2}(\mathrm{~g})}=1$. The fugacity coefficient for a gas can be considered as a measure of "escaping tendency;" a larger gas phase fugacity indicates more of a propensity to dissolve, or to escape from the gas phase. The presence of gases that chemically repel $\mathrm{CO}_{2}(\mathrm{~g})$ would tend to increase the fugacity coefficient of $\mathrm{CO}_{2}(\mathrm{~g})$, and thus increase its solubility. Qualitative arguments regarding the repulsive behavior of $\mathrm{N}_{2}(\mathrm{~g}), \mathrm{H}_{2} \mathrm{~S}(\mathrm{~g}), \mathrm{H}_{2}(\mathrm{~g})$, etc., toward $\mathrm{CO}_{2}(\mathrm{~g})$ are beyond the scope of this memorandum and should be evaluated. However, if it can be shown that the presence of these gases does not increase the product $\phi_{\mathrm{CO}_{2}(\mathrm{~g})} \times \mathrm{y}_{\mathrm{CO}_{2}(\mathrm{~g})}$ above that for a pure carbon dioxide phase, the fugacity of pure $\mathrm{CO}_{2}(\mathrm{~g})$ can serve as a useful upper bound on the $\mathrm{CO}_{2}(\mathrm{~g})$ fugacity in the post-closure waste room environment.

Fugacity Model Results: Calculated $\mathrm{CO}_{2}$ (g) Fugacity versus Pressure

Duan et al. (1992) present a model for the fugacity of pure $\mathrm{CO}_{2}(\mathrm{~g})$ valid for $0^{\circ}$ to $1000^{\circ} \mathrm{C}$ and 0 to 8000 bars ( 0 to $7895 \mathrm{~atm}$ ) pressure. The equation of state has 15 parameters to cover this temperature and pressure range; details can be found in the referenced article. The model of Duan et al. (1992) was implemented in a FORTRAN computer program for the calculations in this memorandum. The calculated fugacity coefficients for $\mathrm{CO}_{2}(\mathrm{~g})$ for $0^{\circ} \mathrm{C}$ and $100^{\circ} \mathrm{C}$ from 1 to 1000 bars varied by less than $0.1 \%$ from those presented in Table 5 of Duan et al. (1992). Thus, the FORTRAN implementation of this $\mathrm{CO}_{2}(\mathrm{~g})$ fugacity model was considered to be verified for conditions bracketing those examined in this memorandum. 
The fugacity of $\mathrm{CO}_{2}(\mathrm{~g})$ as a function of temperature for $20^{\circ}, 30^{\circ}$, and $40^{\circ} \mathrm{C}$, and for pressures from 1 to $200 \mathrm{~atm}$ was calculated and plotted in Figure 4. These temperatures were chosen because the repository horizon is approximately $28^{\circ} \mathrm{C}$ (section 1.10.1, Brush, 1990). This pressure range was chosen because lithostatic pressure, the existing confining pressure at the repository horizon, is approximately $150 \mathrm{~atm}$ (Figure 2.2.6, p. 2-10, WIPP Performance Assessment Division, 1991).

The low pressure limit of $f \rightarrow P$ holds for $P<10$ atm, as expected. Temperature has little effect below $\sim 50 \mathrm{~atm}$, above which the model predicts that the $20^{\circ} \mathrm{C}$ spread in temperature between $20^{\circ} \mathrm{C}$ and $40^{\circ} \mathrm{C}$ may be important.

\section{Implications for Design of High Pressure Tests with $\mathrm{CO}_{2}(\mathrm{~g})$}

Several liter-scale tests with high $\mathrm{CO}_{2}(\mathrm{~g})$ pressures are planned to investigate the effects of dissolved carbon dioxide on actinide solubilities; high $\mathrm{CO}_{2}(\mathrm{~g})$ fugacities will emphasize these effects. The $\mathrm{T}=30^{\circ} \mathrm{C}$ curve in Figure 4 suggests that below $\sim 65 \mathrm{~atm}$, the linear relationship $\mathrm{f}_{\mathrm{CO}_{2}(\mathrm{~g})} \approx 0.69 \mathrm{P}$ holds, while above $\sim 65 \mathrm{~atm}$, the linear relationship $\mathrm{f}_{\mathrm{CO}_{2}(\mathrm{~g})} \approx 0.12 \mathrm{P}$ holds. Thus, above $65 \mathrm{~atm}$, the increase in $\mathrm{CO}_{2}(\mathrm{~g})$ fugacity with pressure is predicted to be much less than for pressures below $65 \mathrm{~atm}$.

As discussed earlier, the SPC Brine composition is unaffected, other than $\mathrm{pH}$ and TIC, for $\mathrm{f}_{\mathrm{CO}_{2}(\mathrm{~g})}$ less than about 300 atm. The fugacity calculations in Figure 4 suggest that $\mathrm{f}_{\mathrm{CO}_{2}(\mathrm{~g})}$ will remain well below 100 atm for pressures expected under post-closure conditions. Therefore, it is reasonable to expect that the presence of $\mathrm{CO}_{2}(\mathrm{~g})$ under high pressures in contact with SPC Brine will affect only the $\mathrm{pH}$ and the dissolved $\mathrm{CO}_{2}(\mathrm{~g})$ content. High $\mathrm{CO}_{2}(\mathrm{~g})$ fugacities are thus expected to have a large impact on actinide solubilities by affecting $\mathrm{pH}$ and dissolved $\mathrm{CO}_{2}$ content, but not through modification of the gross brine composition.

The critical point of pure $\mathrm{CO}_{2}(\mathrm{~g})$ is $\mathrm{T}_{\mathrm{c}}=31.05^{\circ} \mathrm{C}$ and $\mathrm{P}_{\mathrm{c}}=73.825$ bar $(72.860$ atm) (Duan et al., 1992). If operation at conditions near or above the critical point is expected to cause experimental difficulties, it would not be unreasonable to lower the pressures to move the system away from the critical point, for example, 
from 80 bar to 50 bar. Such a decrease in operating pressure would move the system well away from the critical point, yet the $30 \mathrm{~atm}$ decrease in total pressure would decrease the $\mathrm{CO}_{2}(\mathrm{~g})$ fugacity only about $11 \mathrm{~atm}$. As can be seen from Figures 1 through 3 , the brine model predicts that this would cause little change in the brine composition, and only small changes in the $\mathrm{pH}$ and total dissolved $\mathrm{CO}_{2}(\mathrm{~g})$. Thus, such a decrease in total pressure may simplify experimental protocol with little affect on the brine composition.

\section{Conclusions}

Brine and gas phase modeling suggest that gaseous carbon dioxide will have little influence on concentrations of major brine constituents when the CO2(g) partial pressure is within current estimates for the WIPP disposal room environment. The only conditions predicted to be affected are the $\mathrm{pH}$ and the total dissolved carbon dioxide concentration. This work also suggests that experimental studies up to about 2 molal TIC may be sufficient to parameterize models for actinide solubilities as functions of dissolved carbon dioxide.

\section{References}

Brush, L.H. 1990. Test Plan for Laboratory and Modeling Studies of Repository and Radionuclide Chemistry for the Waste Isolation Pilot Plant. SAND90-0266. Albuquerque, New Mexico: Sandia National Laboratories.

Duan, Z., N. Møller, and J.H. Weare. 1992. "An Equation of State for the $\mathrm{CH}_{4}-\mathrm{CO}_{2} \cdot \mathrm{H}_{2} \mathrm{O}$ System: I. Pure Systems from 0 to $1000^{\circ} \mathrm{C}$ and 0 to 8000 Bar." Geochimica et Cosmochimica Acta vol. 56: 2605-2617.

Felmy, A.R., and J.H. Weare. 1986. "The Prediction of Borate Mineral Equilibria in Natural Waters: Application to Searles Lake, California." Geochimica et Cosmochimica Acta vol. 50: 2771-2783.

Harvie, C.E., N. Møller, and J.H. Weare. 1984. "The Prediction of Mineral Solubilities in Natural Waters: The Na-K-Mg-Ca-H-Cl-SO $-\mathrm{OH}-\mathrm{HCO}_{3}-\mathrm{CO}_{3}-\mathrm{CO}_{2}-\mathrm{H}_{2} \mathrm{O}$ System to High Ionic Strength at $25^{\circ} \mathrm{C}$." Geochimica et Cosmochimica Acta vol. 48: 723-751.

Knauss, K.G., T.J. Wolery, and K.J. Jackson. 1990. "A New Approach to Measuring pH in Brines and Other Concentrated Electrolytes." Geochimica et Cosmochimica Acta vol. 54: 1519-1523.

Knauss, K.G., T.J. Wolery, and K.J. Jackson. 1991. "Reply to Comment by R.E. Mesmer on 'A New Approach to Measuring $\mathrm{pH}$ in Brines and Other Concentrated Electrolytes'." Geochimica et Cosmochimica Acta vol. 55: 1177-1179. 
Mesmer, R.E. 1991. "Comments on 'A New Approach to Measuring pH in Brines and Other Concentrated Electrolytes' by K.G. Knauss, T.J. Wolery, and K.J. Jackson." Geochimica et Cosmochimica Acta vol. 55: 1175-1176.

Molecke, M.A. 1983. A Comparison of Brines Relevant to Nuclear Waste Experimentation. SAND83-0516. Albuquerque, New Mexico: Sandia National Laboratories.

Novak, C.F. 1993. "Transport Modeling in a Finite Fractured Rock Domain," in Materials Research Society Symposium Proceedings. Volume 294. Scientific Basis for Nuclear Waste Management XVI. C.G. Interrante and R.T. Pabalan, editors. Pittsburgh, Pennsylvania: Materials Research Society. Vol. 294, 831-838.

Novak, C.F., and S.D. Sevougian. 1993. "Propagation of Dissolution/Precipitation Waves in Porous Media," in Migration and Fate of Pollutants in Soils and Subsoils. NATO ASI Series. Series G: Ecological Sciences, Vol. 32. D. Petruzzelli and F.G. Helfferich, editors. Berlin, Germany: Springer-Verlag. Vol. 32, 275-307. Also published as SAND920364. Albuquerque, New Mexico: Sandia National Laboratories.

Smith, J.M., and H.C. Van Ness. 1975. Introduction to Chemical Engineering Thermodynamics. New York: McGraw-Hill.

WIPP Ferformance Assessment Division. 1991. Preliminary Comparison with 40 CFR Part 191, Subpart B for the Waste Isolation Pilot Plant, December 1991. Volume 3: Reference Data. SAND91-0893/3. Albuquerque, New Mexico: Sandia National Laboratories.

Copies to:

$\begin{array}{llll}\text { DOE/WPIO } & \text { R. Houck } & 6119 & \text { C.F. Novak } \\ \text { DOE/WPIO } & \text { P. Higgins } & 6119 & \text { H.W. Papenguth } \\ \text { FSU } & \text { G.R. Choppin } & 6119 & \text { File } \\ \text { LBL } & \text { H. Nitsche } & 6121 & \text { J.R. Tillerson } \\ \text { LLNL } & \text { R.J. Silva } & 6300 & \text { D.E. Ellis } \\ \text { PNL } & \text { A.R. Felmy } & 6303 & \text { W.D. Weart } \\ \text { PNL } & \text { D. Rai } & 6305 & \text { S.A. Goldstein } \\ \text { RE/SPEC } & \text { Steve Alcorn } & 6341 & \text { A.L. Stevens } \\ & & 6342 & \text { D.R. Anderson } \\ 6100 & \text { R.W. Lynch } & 6345 & \text { R.C. Lincoln } \\ 6115 & \text { P.B. Davies } & 6345 & \text { M.L.F. Phillips } \\ 6115 & \text { M.D. Siegel } & 6348 & \text { J.T. Holmes } \\ 6118 & \text { H.R. Westrich } & 6348 & \text { L.H. Brush } \\ 6119 & \text { F. Gelbard } & 6352 & \text { W.B.S. } 1.1 .1 .1 .4,1.1 .5 .2 .2\end{array}$




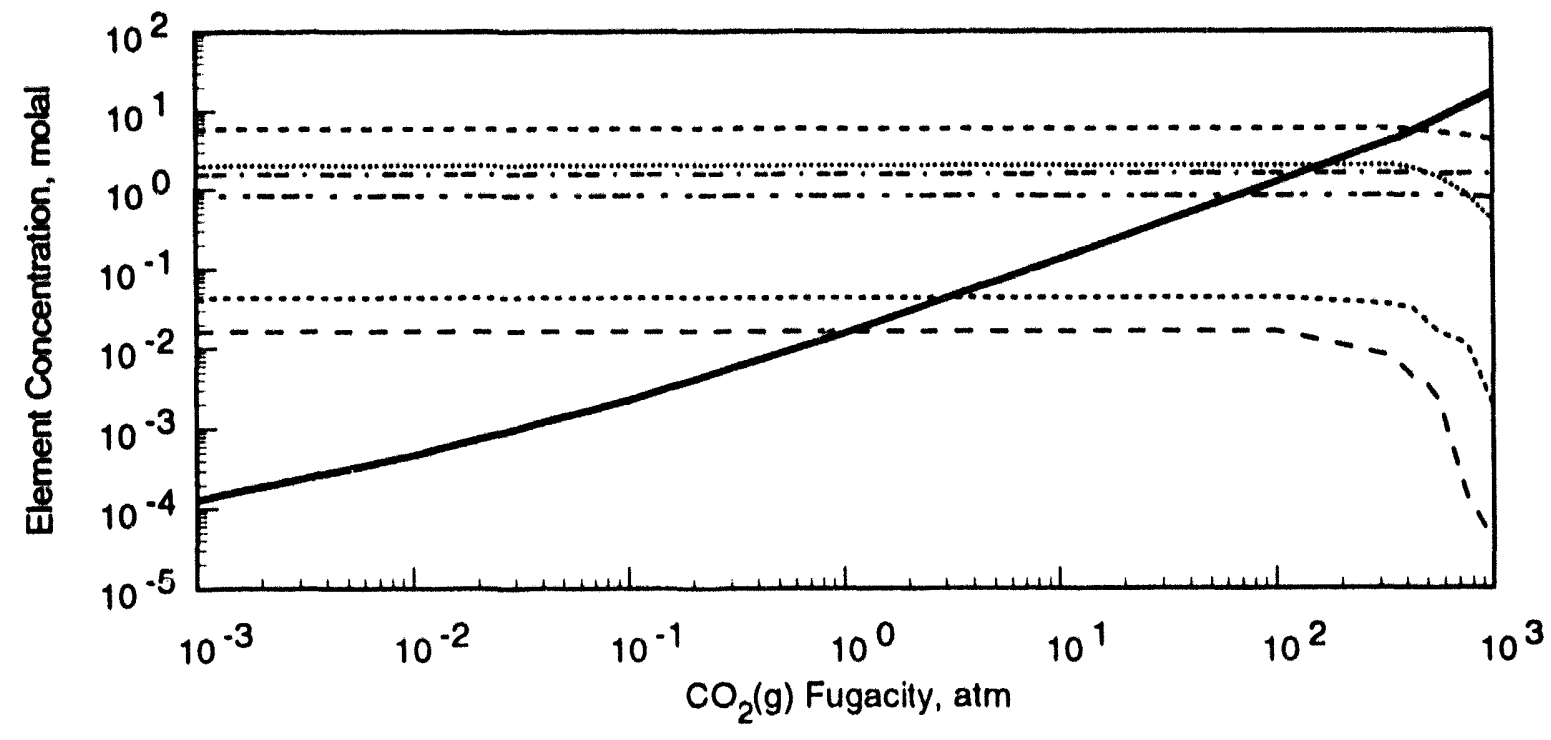

\begin{tabular}{|c|c|c|c|c|c|}
\hline ............ & Sodium Molality & -- & Calcium Molality & $\ldots$. & Sulfur Molality \\
\hline$\cdots$ & Potassium Molality & $\cdots$ & Chlorine Molality & - & $\begin{array}{l}\text { Molality of Total } \\
\text { Inorganic Carbon }\end{array}$ \\
\hline$-\cdots$ & Magnesium Molality & & & & \\
\hline
\end{tabular}

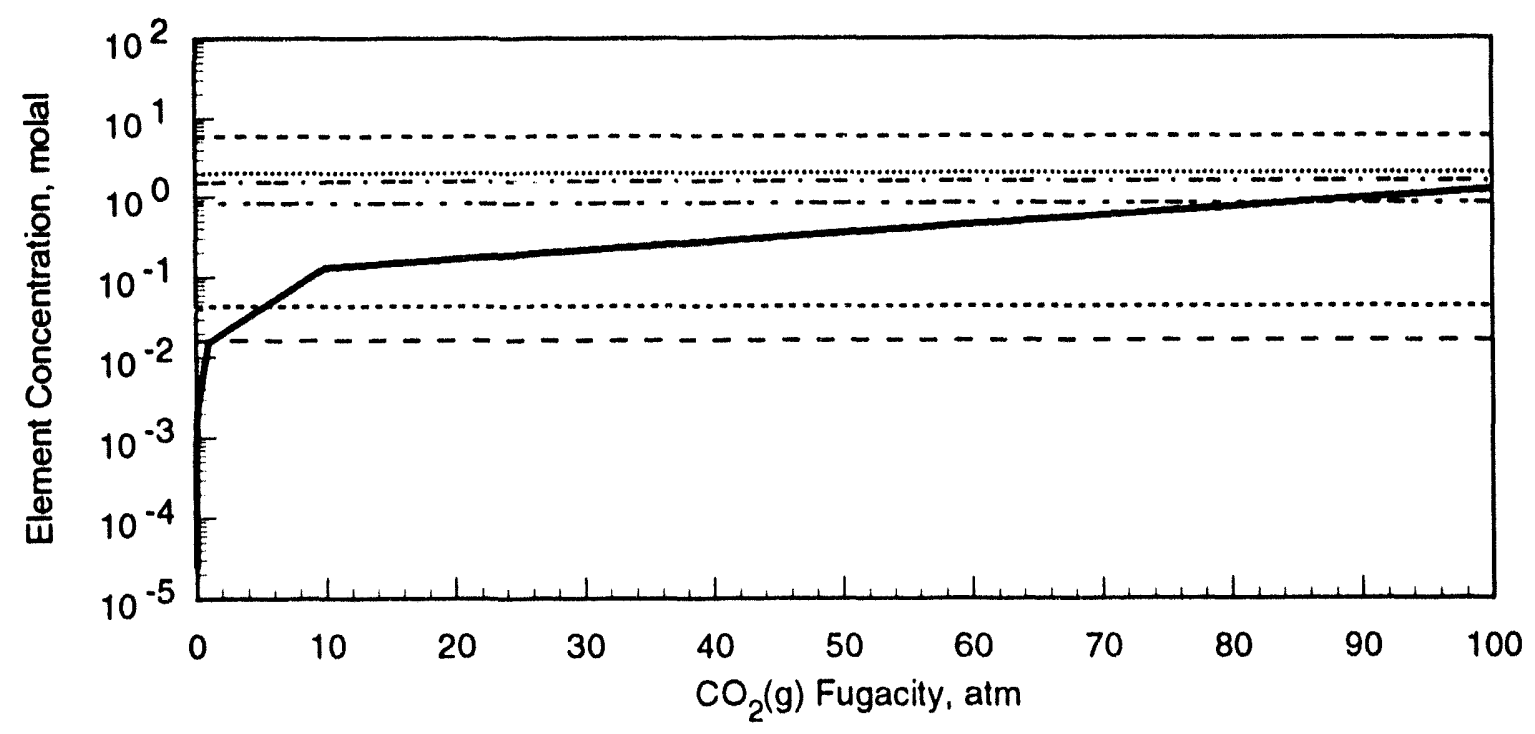

Figure 1. Calculated total element concentrations in SPC Brine as a function of $\mathrm{CO}_{2}(\mathrm{~g})$ fugacity in equilibrium with the brine. 

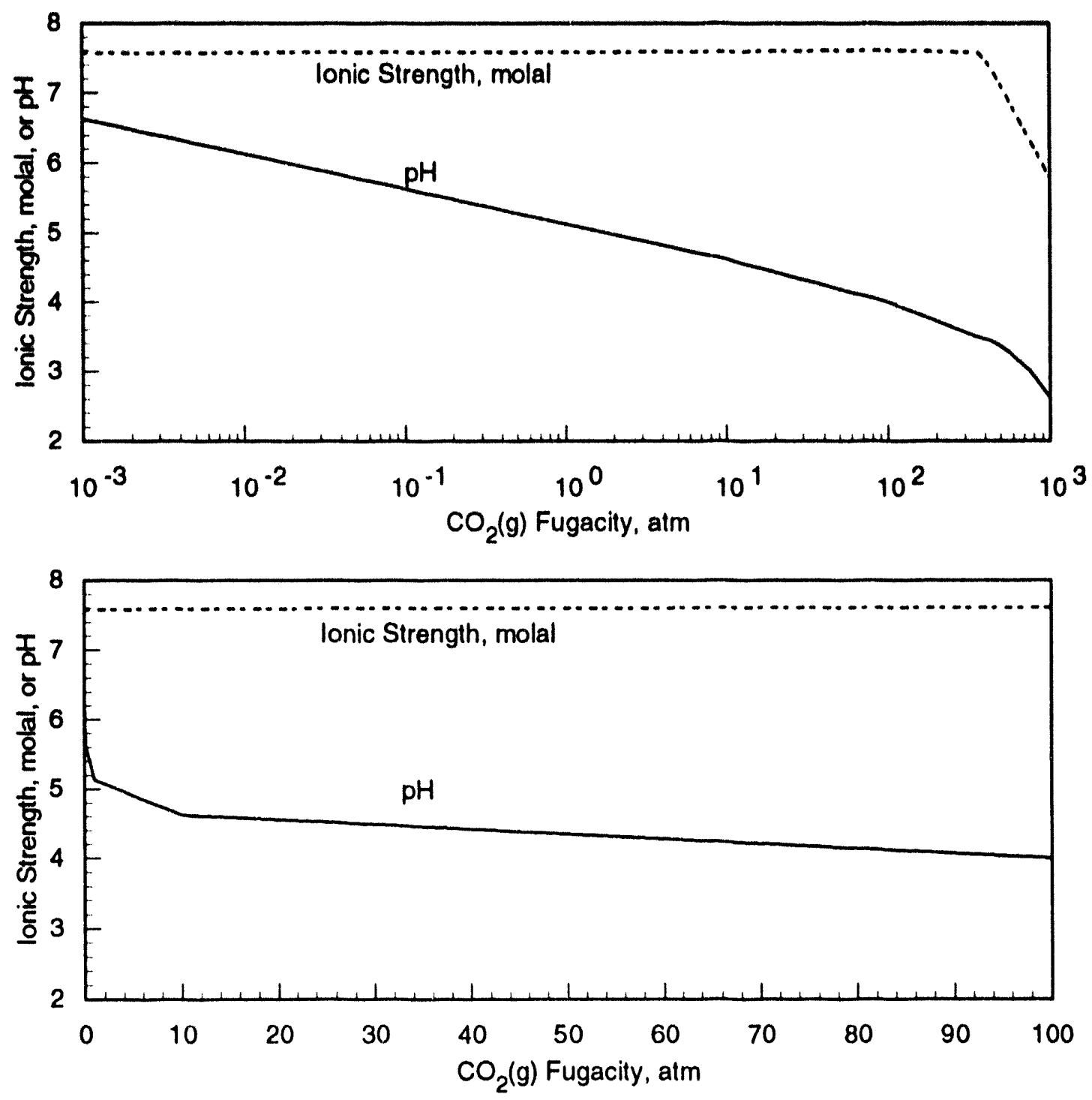

Figure 2. Calculated $\mathrm{pH}$ and ionic strength of $\mathrm{SPC}$ Brine as a function of $\mathrm{CO}_{2}(\mathrm{~g})$ fugacity in equilibrium with the brine. 

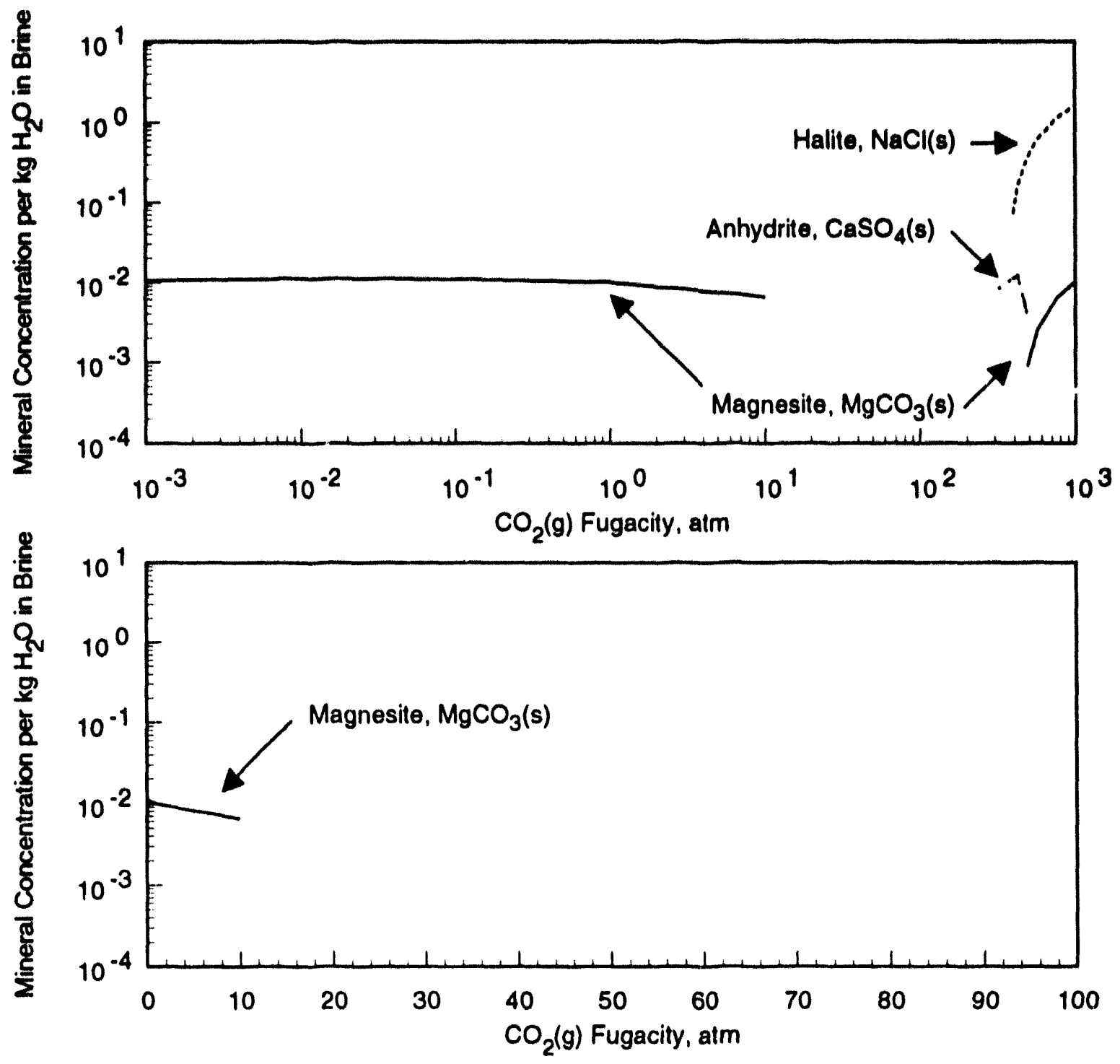

Figure 3. Calculated precipitated solid concentrations as a function of $\mathrm{CO}_{2}(\mathrm{~g})$ fugacity in equilibrium with the brine. 


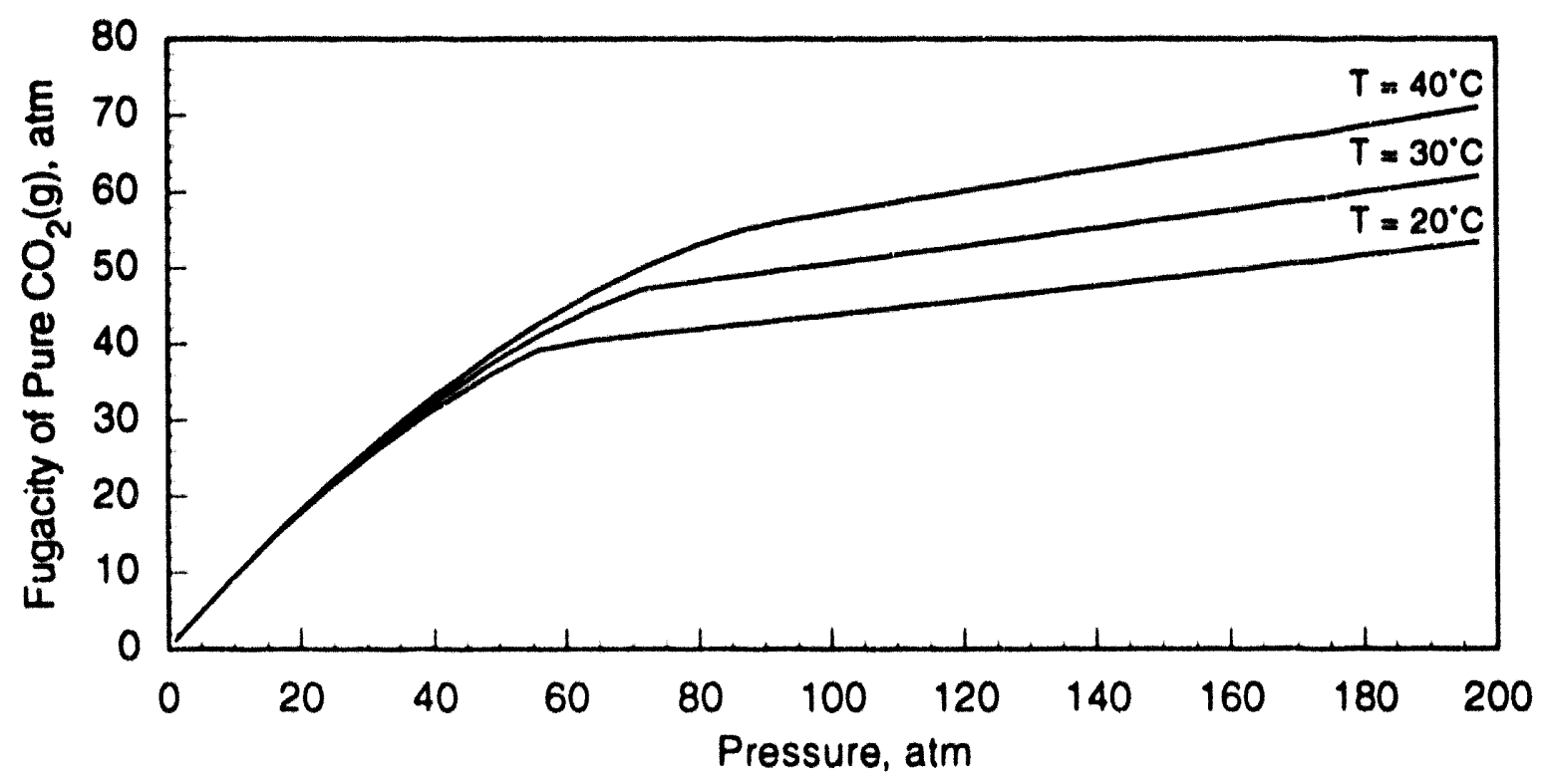

Figure 4. Calculated fugacity of pure $\mathrm{CO}_{2}(\mathrm{~g})$ as a function of pressure at $20^{\circ}$, $30^{\circ}$, and $40^{\circ} \mathrm{C}$.

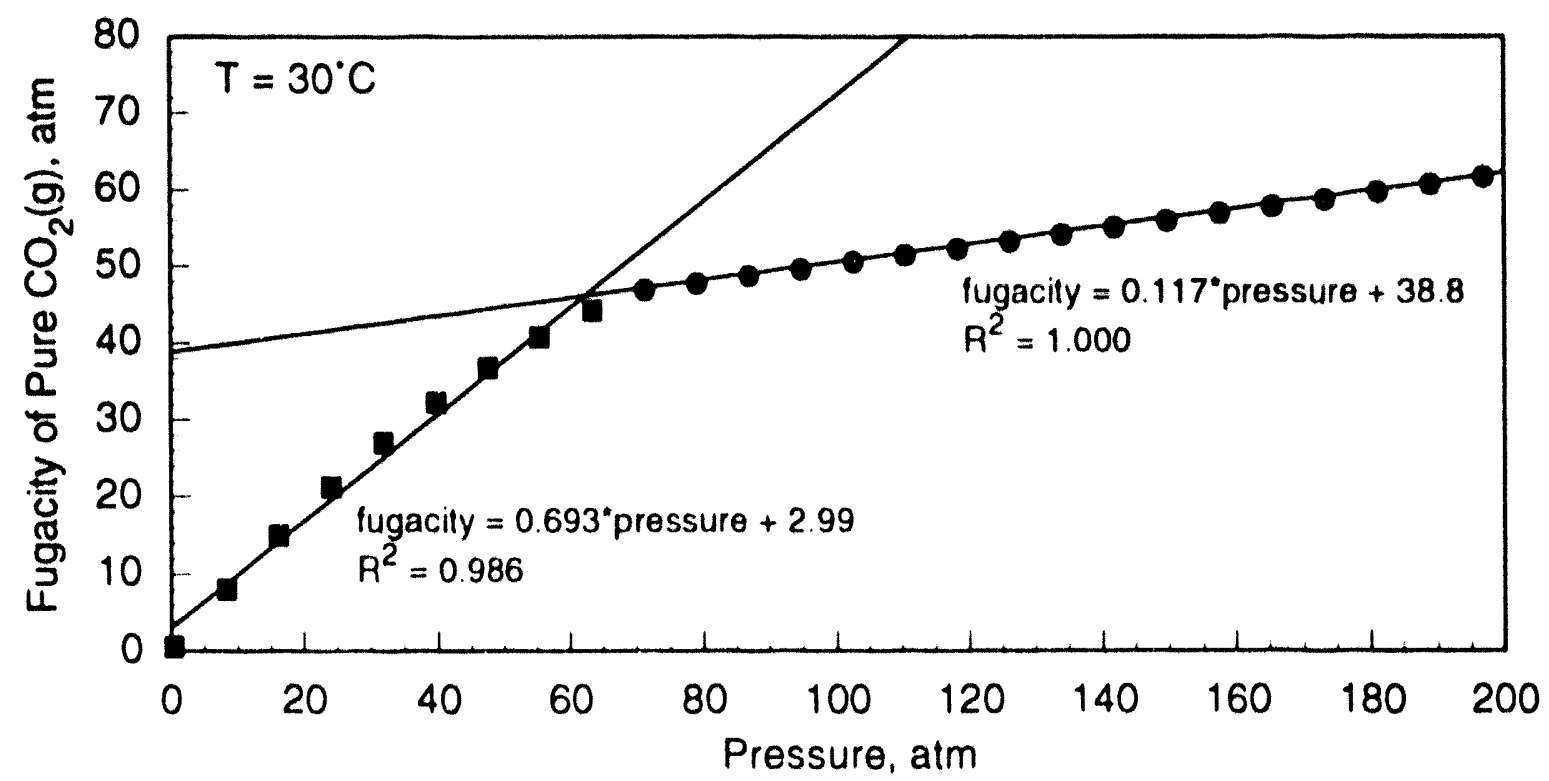

Figure 5. Linear least squares fit for calculated fugacity of pure $\mathrm{CO}_{2}(\mathrm{~g})$ at $30^{\circ} \mathrm{C}$. 
APPENDIX C:

Procedure for Preparing Inoculated Brine

C-1 
C-2 


\section{Appendlx C: Procedure for Preparing Inoculated Brine}

Section 2.4.1 indicates the need for diluting brine obtained from the WIPP underground (e.g., from G-seep) with synthetic brine, as there will otherwise be insufficient brine for conducting the source-term tests. However, synthetic brine does not contain microbes native to the WIPP underground. A procedure has been developed by A. J. Francis et al. (Brookhaven National Laboratory) and M. A. Molecke (SNL) to produce a brine from natural and artificial sources that contains microbial populations that resemble those found in the WIPP underground and at the surface in the vicinity of the WIPP site.

The inoculated brine is prepared by adding 5 parts by volume of the brine inoculant mix described in the following memorandum and 2.5 parts by volume of brine collected from G-seep in the WIPP underground with 92.5 parts by volume of synthetic Brine A. The following reagents yield $200 \mathrm{~L}$ Brine $\mathrm{A}$ when mixed:

$58.42 \mathrm{~kg} \mathrm{MgCl}{ }_{2} \bullet 6 \mathrm{H}_{2} \mathrm{O}$ or $39.73 \mathrm{~kg} \mathrm{MgCl} \cdot 2 \mathrm{H}_{2} \mathrm{O}$

$20.02 \mathrm{~kg} \mathrm{NaCl}$

$11.44 \mathrm{~kg} \mathrm{KCl}$

$1.24 \mathrm{~kg} \mathrm{Na}_{2} \mathrm{SO}_{4}$

$390 \mathrm{~g} \mathrm{Na}_{2} \mathrm{~B}_{4} \mathrm{O}_{7} \cdot 10 \mathrm{H}_{2} \mathrm{O}$

$332 \mathrm{~g} \mathrm{CaCl}_{2}$

$192 \mathrm{~g} \mathrm{NaHCO}_{3}$

$104 \mathrm{~g} \mathrm{NaBr}$

$25.0 \mathrm{~g} \mathrm{LiCl}$

$5.45 \mathrm{~g} \mathrm{RbCl}$

$3.0 \mathrm{~g} \mathrm{SrCl}_{2} \bullet 6 \mathrm{H}_{2} \mathrm{O}$

$2.6 \mathrm{~g} \mathrm{KI}$

$2.5 \mathrm{~g} \mathrm{FeCl}_{3} \bullet 6 \mathrm{H}_{2} \mathrm{O}$

$0.25 \mathrm{~g} \mathrm{CsCl}$

$2.5 \mathrm{~mL} 12 \mathrm{~N} \mathrm{HCl}$

$\mathrm{H}_{2} \mathrm{O}$, deionized, to $200 \mathrm{~L}$

Reagents are added to water in a plastic barrel while stirring, using an electric mixer. $\mathrm{MgCl}_{2}$ should be added to the water and dissolved prior to adding the other reagents. After all reagents are dissolved, water is added to yield a total volume of $200 \mathrm{~L}$. No solids should precipitate from the mixture. This recipe may be scaled as appropriate.

The complete procedure is described in the following memo. 


\title{
BROOKHAVEN NATIONAL LABORATORY \\ MEMORANDUM
}

\author{
DATE: $\quad$ August 16,1993 \\ TO: $\quad$ Marty Molecke, Sandia National Laboratories \\ FROM: J.B. Gillow and A.J. Francis \\ SUBJECT: Details of the Preparation of a Mixed Inoculum for the Bin Tests [Revised]
}

The following describes the components, preparation, addition, and storage of a mixed inoculum to be used for large-scale bin tests. A mixed inoculum has been effectively used in laboratory studies at Brookhaven National Laboratory (BNL) to: (i) examine the activity of specific groups of microorganisms such as cellulose degraders, denitrifiers and fermenters and (ii) examine gas generation due to biodegradation of cellulose under inundated and humid hypersaline conditions.

The purpose of using a mixed inoculum is to provide diverse groups of microorganisms for the test system without specifically pre-enriching for a group of microbes with a limited metabolic function. The dominant groups will be selected by the most abundant substrates in the test system.

The mixed inoculum used at BNL has essentially been G-Seep brine from the repository amended with aliquots from various sources: a brine solution prepared by dissolving halite from the WIPP underground workings in distilled water and brine and sediment slurry from surficial hypersaline lakes adjacent to the WIPP site. The mixture consisted of $50 \%$ G-Seep brine, $30 \%$ $(200 \mathrm{~g} / \mathrm{L})$ muck pile salt, and $20 \%$ brine and sediment slurry from 5 surficial lakes. Bacteria have been detected in brine from the surficial lakes $\left(10^{6}-10^{7} \mathrm{cells} / \mathrm{ml}\right)$, G-Seep brine $\left(10^{4}-10^{6} \mathrm{cell} / \mathrm{s} / \mathrm{ml}\right.$ ) and in the muck pile salt.

Inoculum Preparation: The inoculum is composed of: i) G-Seep brine from the WIPP repository, ii) muck pile salt from the WIPP underground workings, and iii) brine and sediment slurry from the lakes adjacent to the WIPP site. The G-Seep and muck pile salt can be stored at room temperature prior to preparation. The sediment and lake brine should be stored at $4^{\circ} \mathrm{C}$ soon after collection. Microbial activity in the sediment and lake brine should be minimized as much as possible prior to preparation of the inoculum in order to prevent the proliferation and enrichment of specific microorganisms due to the metabolism of nutrients (if any) present in the samples. This is not a problem with G-Seep as it contains very low levels of dissolved organic carbon (DOC), and it has been shown to maintain a steady population of $10^{4}$ viable cells $/ \mathrm{ml}$ when stored at room temperature. 
COMPOSITION OF MIXED INOCULUM

\begin{tabular}{|c|c|c|c|}
\hline \multicolumn{3}{|c|}{ SOURCE } & Volume (ml) \\
\hline \multicolumn{3}{|c|}{ G-Seep brine from the WIPP underground workings } & 2500 \\
\hline \multicolumn{3}{|c|}{$\begin{array}{l}\text { Muck pile salt from the WIPP underground workings } \\
\text { Dissolve } 200 \mathrm{~g} / \mathrm{L} \text { S2 } 180, \text { W30 in distilled water and stir for } \\
2 \text { hours in a sterile glass crlenmeyer flask. }\end{array}$} & 1500 \\
\hline \multicolumn{3}{|c|}{$\begin{array}{l}\text { Sediment slurry and brine from the WIPP surficial environment are } \\
\text { mixed together in the above solution. }\end{array}$} & \multirow[b]{7}{*}{1000} \\
\hline Laguna Quatro & 100 & 100 & \\
\hline Laguna Cinco & 100 & 100 & \\
\hline Laguna Tres South & 100 & 100 & \\
\hline Lindsey Lake & 100 & 100 & \\
\hline Suprise Springs & 100 & $\underline{100}$ & \\
\hline Total & 500 & 500 & \\
\hline \multicolumn{3}{|c|}{ TOTAL. } & 5000 \\
\hline
\end{tabular}

Particulates present in the sediment can be removed by passing through sterile cotton.

The above components are combined in a $6.0 \mathrm{~L}$ sterile erlenmeyer flask under anoxic conditions in a $\mathrm{N}_{2}$ atmosphere and stirred. Aliquots of the mixed inoculum are removed and analyzed for:

i) The total number of bacteria by direct microscopic counts using the DAPI (4',6-diamidino-2-phenylindole dihydrochloride) method, and viable cells by microscopic examination with a redox indicator 5-cyano-2, 3-ditolyl tetrazolium chloride (CTC).

ii) Inoculum activity by assaying for denitrification (acetylene blockage technique).

iii) Total and dissolved organic carbon.

iv) The distribution of microorganisms (aerobes, anaerobes, denitrifiers, sulfate reducers and methanogens) by the most probable number (MPN) technique.

v) Chemical characteristics such as $\mathrm{pH}$, organic acids, $\mathrm{NH}_{4}{ }^{+}, \mathrm{NO}_{3}{ }^{-}, \mathrm{PO}_{4}{ }^{3 \cdot}$, and $\mathrm{SO}_{4}{ }^{3}$.

Information on the characteristics of the inoculum for large-scale tests is essential in order to establish a baseline fiom which changes in the microbial populations can be monitored by sampling the brine in the test bins during the course of the experiment. Changes in the mic obial community will have a direct impact on the rates and types of gaseous and liquid metabolitic products generated. 
Addition of Inoculum Mixture to a Test-Bin: The mixed inoculum can then be added in the appropriate quantity directly to a $100 \mathrm{~L}$ test bin to provide approximately a $3-5 \% \mathrm{v} / \mathrm{v}$ inoculum. The inoculum should be added to a pre-inundated bin in order to disperse the inoculum throughout the bin. It is adviseable to add the inoculum at the start of the experiment in order to prevent unnecessary perturbations of the test system later.

Storage of the Inoculum Mixture: The inoculum mixture should be stored at $4^{\circ} \mathrm{C}$ in order to prevent the growth of microorganisms in the mixture. Activity may occur if the mixture is allowed to stay at room temperature for more than 24 hours due to the presence of DOC in the inoculum. 
APPENDIX D:

Release versus Solubility Scatterplots

D-1 
date: September 28, 1993

to: Mark (L. F.) Philips, 1846

from: Jon Helton and Jim Garner, 6342

subject: Release verus Solubility Scatterplots

Enclosed are scatterplots for release to the Culebra versus solubility for the radionuclides Am-241, U-234 Th-230, Np-237 and Pu-239 and scenario $S^{+-}(2,0,0,0,0)$ generated with results from the 1991 WIPP PA calculated with the assumption of no gas generation in the repository. The plots for Pu-239, U-234 and Am-241 used the same model predictions used in the generation of Figures 5.1-5 (lower right), 5.1-6 (lower right) and 5.1-7 (lower right) of SAND91-0893/4. Although obtained in the same calculations as the results for Pu-239, U-234 and Am-241, the scatterplots for Np-237 and Th-230 have not been previously published.

Distribution:

0345 Richard C. Lincoln

6345 E. James Nowak

6345 Chris C. Crafts

SWCF AST/STTP 


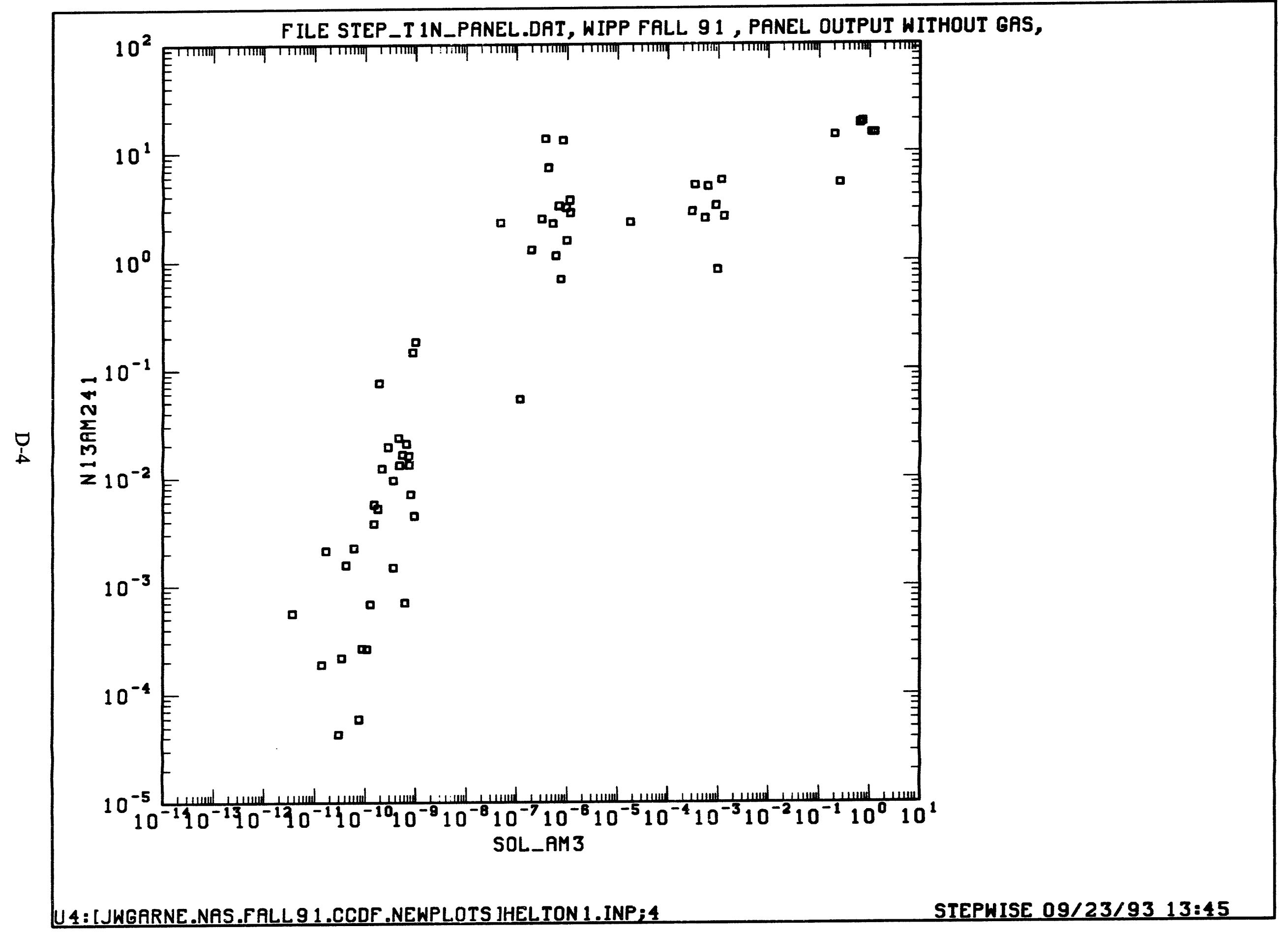




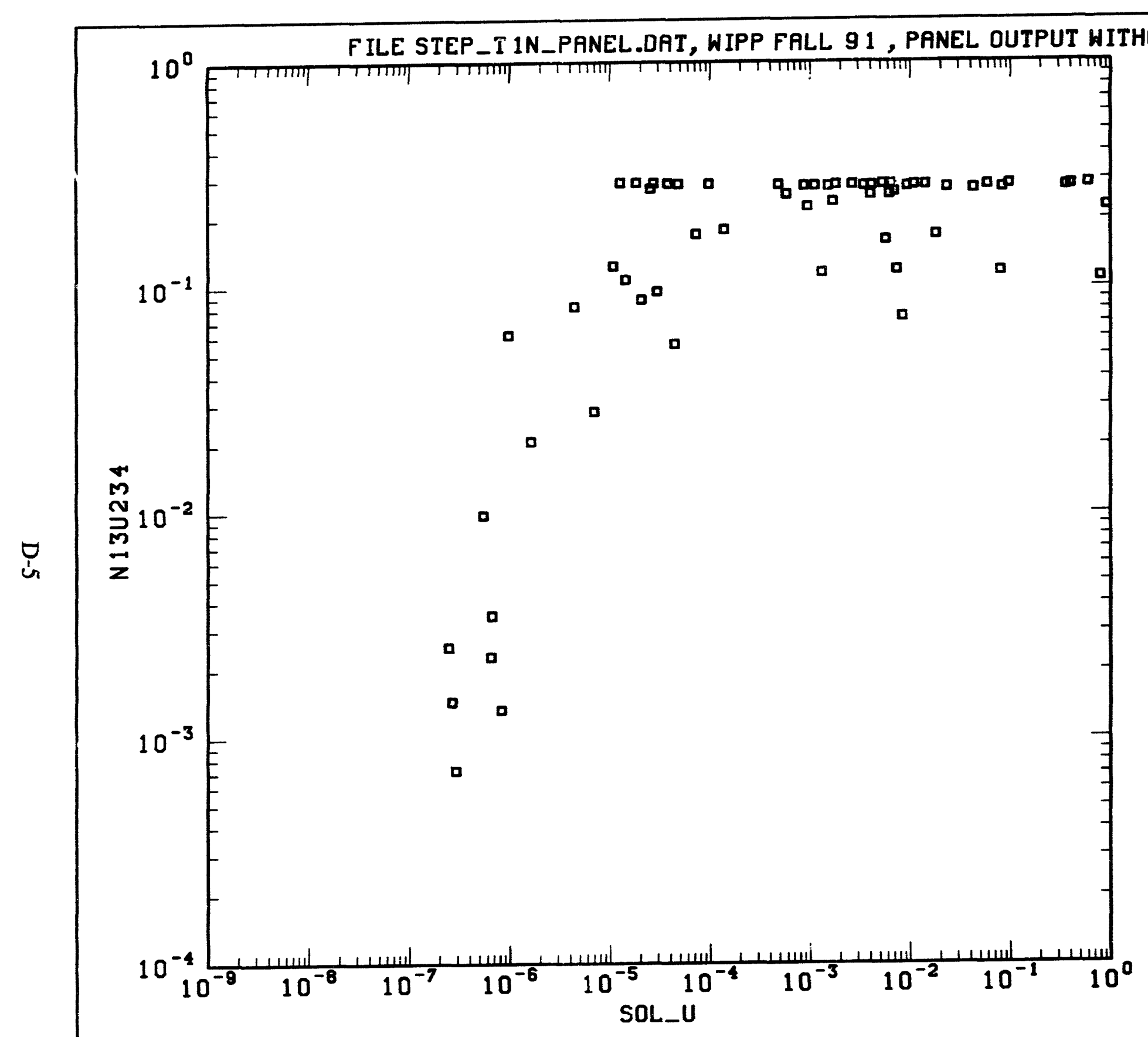




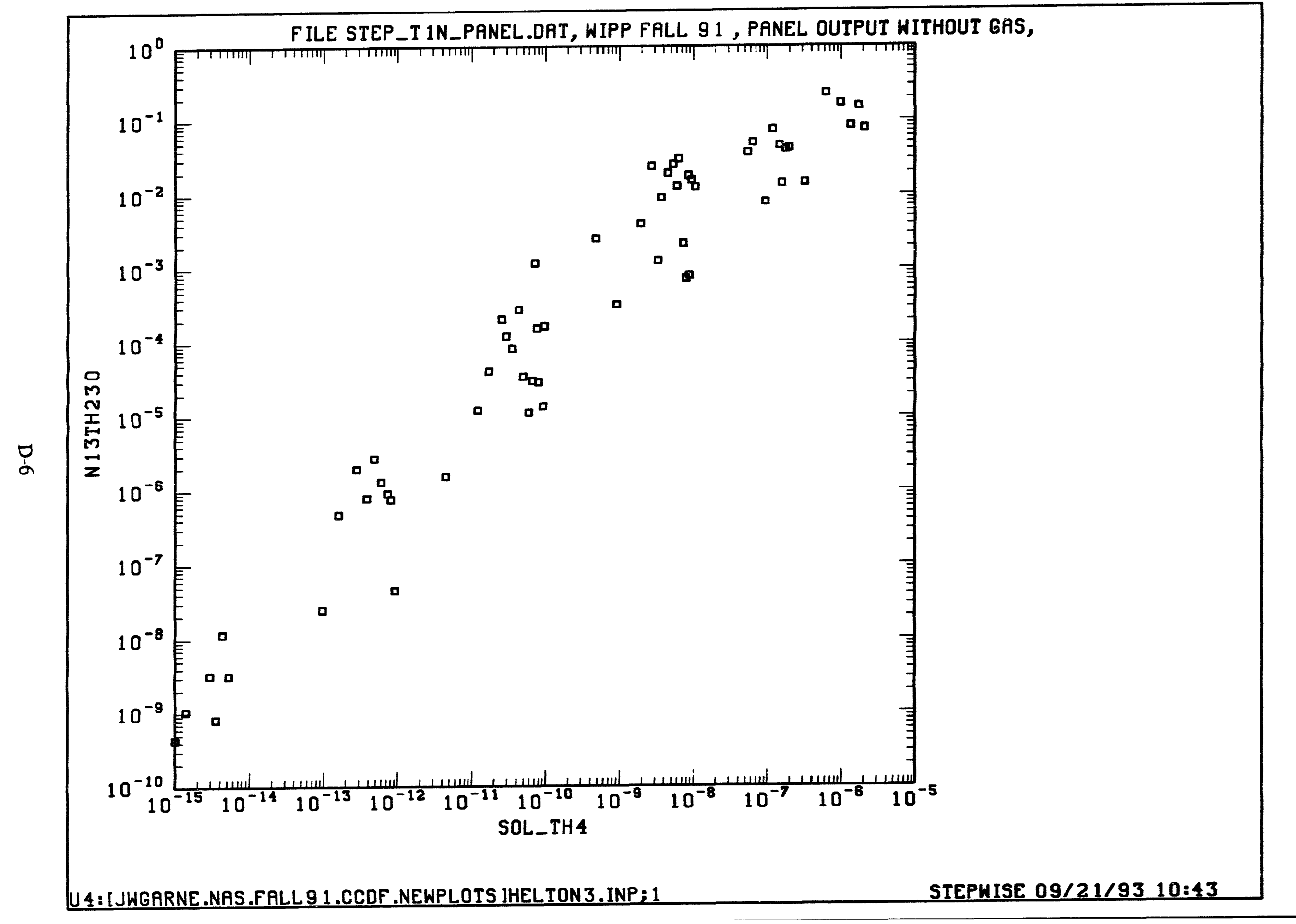


FILE STEP_T IN_PANEL.DAT, WIPP FALL 91 , PANEL OUTPUT WITHOUT GAS,

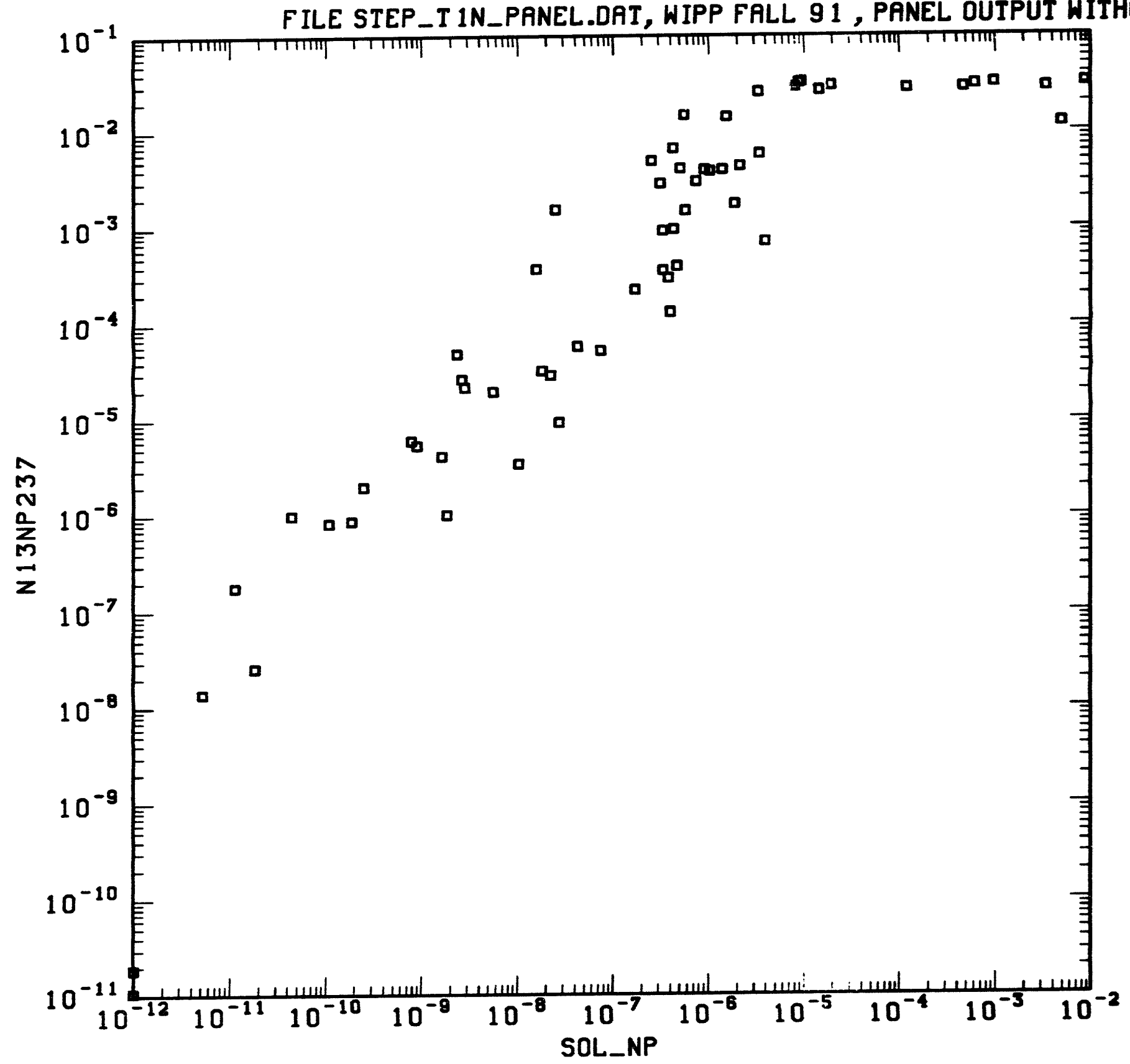

U4: [ JWGARNE. NAS.FALL 9 1.CCDF. NEWPLOTS ]HELTON5.INP; 1 


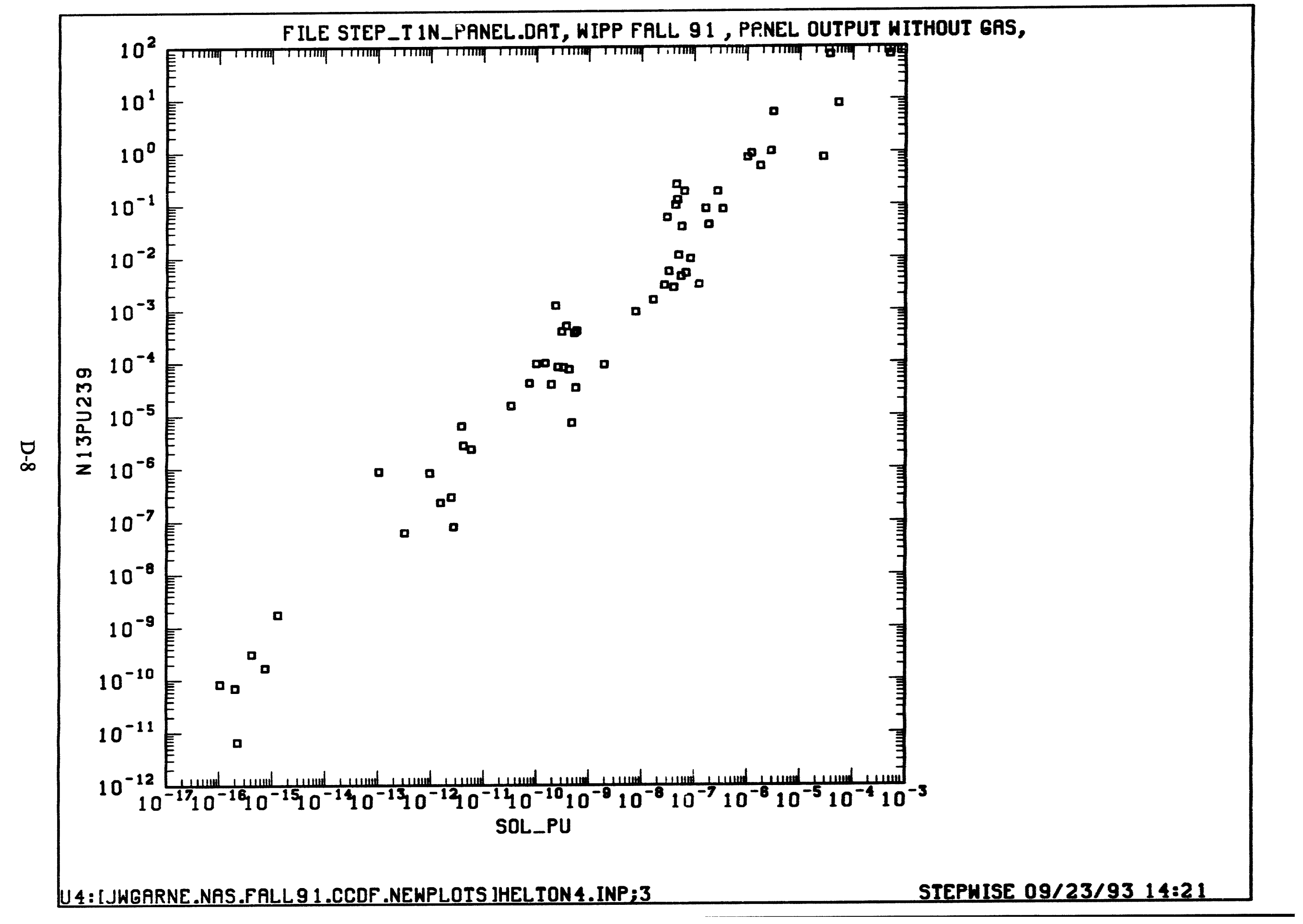



APPENDIX E:

Cement Leaching

E-1 


$$
\text { E-2 }
$$




\section{Appendix E: Cement Leaching}

In order to determine the sieve size cemented wastes should be ground to pass prior to their use in the source-term tests, we must first learn how rapidly the potentially soluble solids (e.g., actinides) in the cement can be leached into solution. This can be done by mixing up Portland cement and Envirostone with water containing dissolved cesium ion, allowing the cement to set, placing pieces of the cement in Brine A, and agitating. Cesium is used because its leach rate will be unaffected by its solubility in brine (since it is very highly soluble), and it is easily detected in the presence of other alkali ions by flame atomic emission spectroscopy (AES). Using radioactive $C s$ would permit quantification by liquid scintillation.

Assuming the brine volumes and concentrations of Cs within the cement blocks are known, the fraction of Cs leached out of the block can be followed with time. Although estimates of the time required to completely leach pieces of any size can be made by using blocks of a single size, leaching pieces of different size (e.g., 1, 2, 5, 10, and $20 \mathrm{~cm}^{3}$ spheres or cubes) will yield more reliable results. These experiments will be used to predict the maximum size of cemented waste that will be brought to equilibrium with the brine within the test period, and ideally within six months. 
APPENDIX F:

Brine-Backfill Ratio

F-1 
F-2 


\section{Appendix F: Brine-Backfill Ratio}

Though it is possible to predict the ratio of brine to backfill material in fully inundated disposal rooms (within a fairly wide range of uncertainty), this may not be the appropriate ratio to use in the test containers. Enough free liquid must be present to allow sampling of leachate from the containers; this will not occur if all of the brine is soaked into the backfill material. To determine the proper ratio, mixtures of brine with bentonite in varying proportions will be shaken for a period of two weeks, then allowed to settle for one day. The percentage of free liquid volume in the sample will be estimated. A portion of the free liquid will then be filtered through a $1 \mu \mathrm{m}$ filter, and filtration velocity $(\mathrm{mL} / \mathrm{min})$ will be measured. This will determine whether such a sample, if drawn as leachate, would clog the pre-filter used to prepare leachate samples for subsequent workup. The results from this simple experiment will be used to calculate the ratio of brine to backfill appropriate for the source-term tests, and thus the amount of bentonite to be added to the test containers requiring backfill (Appendix A).

The quantity of brine required in the liter scale experiments containing sludges will be determined through a similar experiment in which brine is mixed with a synthetic inorganic sludge. This material will be prepared by precipitating ferric hydroxide from aqueous solution and filtering the suspension through diatomaceous silica. 
APPENDIX G:

Steel Additive

G-1 


\section{Appendix G: Steel Additive}

The STTP requires that most test vessels (drum and liter-scale) contain iron or mild steel in order to simulate the effects of container corrosion in the post-closure WIPP disposal rooms. As was specified in Section 3.3, the surface area of the steel added to the drum-scale tests must be equivalent to that of a standard $55 \mathrm{gal}$. waste drum, which is approximately $4 \mathrm{~m}^{2}$ (considering both internal and external surface). The liter scale tests require corrodant with area equal to (4 $\mathrm{m}^{2}$ )(waste volume/210 L).

The steel is expected to corrode at an average rate of $0.21 \mathrm{~mol} / \mathrm{m}^{2}$ under anoxic conditions in WIPP brine (Telander and Westerman, 1993)." Over three years of test operation, the drum scale tests thus require $\left(4 \mathrm{~m}^{2}\right)\left(0.21 \mathrm{~mol} / \mathrm{m}^{2}-\mathrm{yr}\right)(3 \mathrm{yr})=25$ moles of iron per drum. This iron occupies a volume of $(25 \mathrm{~mol})(56 \mathrm{~g} / \mathrm{mol}) /\left(7.8 \mathrm{~g} / \mathrm{cm}^{3}\right)=180 \mathrm{~cm}^{3}$. The iron source added to the drum-scale tests must therefore have a surface area of approximately $4 \mathrm{~m}^{2}$, and a volume of not less than $180 \mathrm{~cm}^{3}$. These requirements can be met efficiently by using steel mesh as the iron source. If this mesh is composed of wire of length $l$ and diameter $d$, then the area $A$ of this wire (ignoring the ends) equals $\pi d l$. The volume of this wire $V$ equals $\pi d^{2} l / 4$. For a three-year test, $V$ must equal or exceed $180 \mathrm{~cm} 3$, and multiplying out the constants yields $d^{2} l=$ $230 \mathrm{~cm}^{3}$. Similarly, $A=4 \times 10^{4} \mathrm{~cm}^{2}$, so $d l=1.3 \times 10^{4}$. Setting $l=\left(1.3 \times 10^{4}\right) / d$ and substituting into the volume equation, we get $\left(d^{2}\right)\left(1.3 \times 10^{4} / d\right)=230$, or $d=0.018 \mathrm{~cm}$. Solving for $l$ yields $l=7.2 \times 10^{5} \mathrm{~cm}^{2}$, or $7.2 \mathrm{~km}$. This wire diameter (approximately $0.2 \mathrm{~mm}$ ) is very fine, but this is of course a minimum specification. A larger wire diameter provides a safety factor, which is desirable because oxic corrosion may also take place in environments where brine radiolysis is significant.

*This corrosion rate value is an average of the $3,6,12$, and 24 -month corrosion rates. The average rate is meaningful only during this period, since corrosion rates decreased steadily with time. For a three year test, the value of $0.21 \mathrm{~mol} / \mathrm{m}^{2}$ is likely to be conservative, assuming that oxic corrosion is not significant. 
Despite the formidable-sounding value of $l$, the area of screen needed to meet the area and volume requirements for the drum-scale tests is actually quite manageable. If we assume a mesh with a wire diameter of $0.1 \mathrm{~cm}$ and a pitch of 5 wires $/ \mathrm{cm}$, a meter-square of this screen will contain 1000 wires of $1 \mathrm{~m}$ length each, or $1 \mathrm{~km}$ of total wire length. From the equation $A=\pi d l$, the length of $0.1 \mathrm{~cm}$ wire that will provide a surface area of $4 \mathrm{~m}^{2}$ is $\left(4 \times 10^{4} \mathrm{~cm}^{2}\right) /(0.1 \mathrm{~cm})(3.14)=1.3 \times 10^{5} \mathrm{~cm}$, or $1.3 \mathrm{~km}$. Each drum-scale test would thus require $1.3 \mathrm{~m}^{2}$ of this mesh. This would contain $\pi d^{2} l / 4=1.0 \times 10^{3} \mathrm{~cm}^{3}$ of steel, or $\left(1.0 \times 10^{3} \mathrm{~cm}^{3}\right)(7.8$ $\left.\mathrm{g} / \mathrm{cm}^{3}\right) /(56 \mathrm{~g} / \mathrm{mol})=140 \mathrm{~mol}$ of iron, or over 5 times that required for a three year test, assuming that only anoxic corrosion takes place.

\section{References}

Telander, M.R., and R.E. Westerman. 1993. Hydrogen Generation by Metal Corrosion in Simulated Waste Isolation Pilot Plant Environments: Progress Report for the Period November 1989 through December 1992. SAND92-7347. Albuquerque, NM: Sandia National Laboratories. 


\section{DISTRIBUTION}

\section{Federal Agencies}

US Department of Energy ( 6 )

Office of Civilian Radioactive Waste Management

Attn: Deputy Director, RW-2

Associate Director, RW-10/50 Office of Program and Resources Management Office of Contract Business Management

Director, RW-22

Analys is and Verification Division

Associate Director, RW-30

Office of Systems and

Compliance.

Associate Director, RW-40

Office of Storage and

Transportation

Director, RW-4/5

Office of Strategic Planning and International Programs Office of External Relations

Forresta1 Building

Washington, DC 20585

US Department of Energy

Albuquerque Operations office

Attn: National Atomic Museum Library

PO Box 5400

Albuquerque, NM 87185-5400

US Department of Energy (4)

WIPP Project Integration Office

Attn: W.J. Arthur III

L.W. Gage

P.J. Higgins

D.A. Olona

Po Box 5400

Albuquerque, NM 87115-5400

US Department of Energy (2)

WIPP Project Integration Satellite

Office

Attn: R. Batra

R. Becker

PO Box 3090, Mail Stop 525

Carlsbad, NM 88221-3090

US Department of Energy

Research \& Waste Management Division Attn: Director

PO Box E

Oak Ridge, TN 37831
US Department of Energy (3)

WIPP Project Site Office (Carlsbad)

Attn: V. Daub

$J$. Lippis

J.A. Mewhinney

PO Box 3090

Carlsbad, NM 88221-3090

US Department of Energy

Attn: E. Young

Room E- 178

GAO/RCED/GTN

Washington, DC 20545

US Department of Energy

Office of Environmental Restoration and Waste Management

Attn: J. Lytle, EM-30, Trevion II

Washington, DC 20585-0002

US Department of Energy (3)

Office of Environmental Restoration and Waste Management

Attn: M. Frei, EM-34, Trevion II

Washington, DC 20585-0002

US Department of Energy

Office of Environmental Restoration and Waste Management

Attn: S. Schneider, EM-342, Trevion II

Washington, DC 20585-0002

US Department of Energy (2)

Office of Environment, Safety and Health

Attn: C. Borgstrom, EH-25

R. Pelletier, EH-231

Washington, DC 20585

US Department of Energy

Idaho Operations office

Fuel Processing and Waste

Management Division

785 DOE Place

Idaho Falls, ID 83402

US Environmental Protection Agency (2)

Radiation Protection Programs

Attn: M. Oge

ANR -460

Washington, DC 20460 
US Geological Survey (2)

Water Resources Division

Attn: R. Livingston

4501 Indian School NE

Suite 200

Albuquerque, NM 87110

US Nuclear Regulatory Commission Division of Waste Management

Attn: H. Marson

Mail Stop 4-H-3

Washington, DC 20555

\section{Boards}

Defense Nuclear Facilities Safety Board

Attn: D. Winters

625 Indiana Ave. NW, Suite 700

Washington, DC 20004

Nuclear Waste Technical Review

Board (2)

Attn: Chairman

$$
\text { S.J.S. Parry }
$$

1100 Wilson Blvd., Suite 910

Arlington, VA 22209-2297

Advisory Committee on Nuclear Waste

Nuclear Regulatory Commission

Attn: R. Major

7920 Norfolk Ave.

Bethesda, MD 20814

\section{State Agencies}

Environmental Evaluation Group (3)

Attn: Library

7007 Wyoming NE

Suite F-2

Albuquerque, NM 87109

NM Bureau of Mines and Mineral

Resources

Socorro, NM 87801

NM Energy, Minerals, and Natural

Resources Department

Attn: Library

2040 S. Pacheco

Santa Fe, NM 87505

NM Environment Department (3)

Secretary of the Environment

Attn: J. Espinosa

1190 St. Francis Drive

Santa Fe, NM 87503-0968
NM Environment Department

WIPP Project Site

Attn: P. McCasland

PO Box 3090

Carlsbad, NM 88221

\section{Laboratories/Corporations}

Battelle Pacific Northwest

Laboratories

Attn: R.E. Westerman, MSIN P8-44

Battelle Blvd.

Richland, WA 99352

INTERA Inc.

Attn: J.F. Pickens

6850 Austin Center Blvd.

Suite 300

Austin, TX 78731

INTERA Inc.

Attn: W. Stensrud

Po Box 2123

Carlsbad, NM 88221

IT Corporation

Attn: R.F. McKinney

Regional office

5301 Central NE, Suite 700

Albuquerque, NM 87108

Lawrence Livermore National

Laboratory, Transactiniun Institute

Attn: R. Silva

7000 East Ave.

Livermore, CA 94550

Los Alamos National Laboratory

Attn: R. Villarreal, CLS-1 (12)

B. Erdal, INC-12

PO Box 1663

Los Alainos, NM 87544

RE/SPEC, Inc.

Attn: W. Coons

4775 Indian School NE

Suite 300

Albuquerque, NM 87110-3927

$\mathrm{RE} / \mathrm{SPEC}$, Inc.

Attn: J.L. Ratigan

PO Box 725

Rapid City, SD 57709

Southwest Research Institute (2) Nuclear Waste Regulatory Analysis Attn: P.K. Nair

6220 Culebra Road

San Antonio, TX 78228-0510 
SAIC

Attn: D.C. Royer

101 Convention Center Dr.

Las Vegas, NV 89109

SAIC

Attn: H.R. Pratt

10260 Campus Point Dr.

San Diego, CA 92121

SAIC (2)

Attn: M. Davis

$\mathrm{J}$. Tollison

2109 Air Park Rd. SE

Albuquerque, NM 87106

Tech Reps Inc. (3)

Attn: J. Chapman

C. Crawford

T. Peterson

5000 Marble NE, Suite 222

Albuquerque, NM 87110

TRW Environmental Safety Systems Attn: L. Wildman

2650 Park Tower Dr., Suite 1300

Vienna, VA 22180-7306

Westinghouse Electric Corporation (5)

Attn: Library

C. Cox

L. Fitch

B. A. Howard

R. Kehrman

PO Box 2078

Carlsbad, NM 88221

Westinghouse-Savannah River

Technology Center (4)

Attn: N. Bibler

J.R. Harbour

M.J. Plodinec

G.G. Wicks

Aiken, SC 29802

\section{National Academy of Sciences, WIPP Panel}

Howard Adler

Oak Ridge Associated Universities

Medical Sciences Division

PO Box 117

Oak Ridge, TN 37831-0117

Ina Alterman

Board on Radioactive Waste

Management, GF456

2101 Constitution Ave.

Washington, DC 20418
Fred M. Ernsberger

250 Old Mill Road

Pittsburgh, PA 15238

John D. Bredehoeft

Western Region Hydrologist

Water Resources Division

US Geological Survey (M/S 439)

345 Middlefield Road

Menlo Park, CA 94025

Rodney C. Ewing

Department of Geology

University of New Mexico

Albuquerque, NM 87131

Charles Fairhurst, Chairman

Department of Civil and Mineral

Engineering

University of Minnesota

500 Pillsbury $\mathrm{Dr}$. SE

Minneapolis, MN 55455-0220

B. John Garrick

PLG Incorporated

4590 MacArthur Blvd.

Suite 400

Newport Beach, CA 92660-2027

Leonard F. Konikow

US Geological Survey

431 National Center

Reston, VA 22092

Car1 A. Anderson, Director

Board on Radioactive Waste Management

National Research Council

HA 456

2101 Constitution Ave. NW

Washington, DC 20418

Jeremiah O'Driscoll

Jody Incorporated

505 Valley Hill Drive

Atlanta, GA 30350

Christopher 6. Whipple

Clement International

160 Spear St., Suite 1380

San Francisco, CA 94105

\section{Individuals}

P. Drez

8816 Cherry Hills Rd. NE

Albuquerque, NM 87111 
D.W. Powers

Star Route Box 87

Anthony, TX 79821

\section{Universities}

Florida State University Department of Chemistry Attn: G.R. Choppin

Tallahassee, FL 32306

University of New Mexico

Geology Department

Attn: Library

Albuquerque, NM 87131

University of Washington

College of Ocean and

Fishery Sciences

Attn: G.R.Heath

583 Henderson Hall

Seattle, WA 98195

\section{Libraries}

Thomas Brannigan Library

Attn: D. Dresp

106 W. Hadley St.

Las Cruces, NM 88001

Government Publications Department

Zimmerman Library

University of New Mexico

Albuquerque, NM 87131

New Mexico Junior College

Pannell Library

Attn: R. Hill

Lovington Highway

Hobbs, NM 88240

New Mexico State Library

Attn: N. McCallan

325 Don Gaspar

Santa Fe, NM 87503

New Mexico Tech

Martin Speere Menorial Library

Campus Street

Socorro, NM 87810

WIPP Public Reading Roon

Carlsbad Public Library

Attn: Director

$101 \mathrm{~S}$. Halagueno St.

Carlsbad, NM 88220

\section{Foreign Addresses}

Studiecentrum Voor Kernenergie

Centre d'Énergie Nucléaire

Attn: A. Bonne

SCK/CEN Boeretang 200

B-2400 Mo1, BELGIUM

Atomic Energy of Canada, Ltd. (3)

Whiteshell Laboratories

Attn: B. Goodwin

M. Stevens

D. Wushke

Pinewa, Manitoba, CANADA ROE 1LO

Francois Chenevier (2)

ANDRA

Route du Panorama Robert Schimann B.P. 38

92266 Fontenay-aux-Roses, Cedex

FRANCE

Jean-Pierre Olivier

OECD Nuclear Energy Agency

Division of Radiation Protection and Waste Management

38, Boulevard Suchet

75016 Paris, FRANCE

Claude Sombret

Centre d'Études Nucléaires de la

Vallee Rhone CEN/VALRHO

S.D.H.A. B.P. 171

30205 Bagnols-Sur-Ceze, FRANCE

Gesellschaft fur Reaktorsicherheit (2)

Attn: B. Baltes

W. Muller

Schwertnergasse 1

D-5000 Cologne, GERMANY

Bundesanstalt fur leowissenschaften und Rohstoffe

Attn: $M$. Langer

Postfach 510153

3000 Hanover 51, GERMANY

Bundesministeriun fur Forschung und Technologie

Postfach 200706

5300 Bonn 2, GERMANI

Institut fur Tieflagerung (2)

Attn: K. Kuhn

Theodor-Heuss-Strasse 4

D-3300 Braunschweig, GERMANY 
Physikalisch-Technische Bundesanstalt

Attn: P. Brenneke

Postfach 3345

D-3300 Braunschweig, GERMANY

Shingo Tashiro

Japan Atomic Energy Research Inst.

Toka1-Mura, Ibaraki-Ken, 319-11

JAPAN

Netherlands Energy Research Foundation ECN

Attn: L.H. Vons

3 Westerduinweg

PO Box 1

1755 ZG Petten

THE NETHERLANDS

Svensk Kärnbränsleforsorjning $A B$

Attn: F. Karlsson

Project KBS (Kärnbränslesakerhet)

Box 5864

S-102 48 Stockho1m

SWEDEN

Nationale Genossenschaft für die

Lagerung radioaktiver Abfälle (2)

Attn: S. Vomvoris

P. Zuidema

Hardstrasse 73

$\mathrm{CH}-5430$ Wettingen

SWITZERLAND

AEA Technology

Attn: J.H. Rees

D5W/29 Culham Laboratory

Abington, Oxfordshire OX14 3DB

UNITED KINGDOM

AEA Technology

Attn: W.R. Rodwe 11

044/A31 Winfrith Technical Centre

Dorchester, Dorset DT2 8DH

UNITED KINGDOM

AEA Technology

Attn: J.E. Tinson

B4244 Harwell Laboratory

Didcot, Oxfordshire OX11 ORA

UNITED KINGDOM

D.R. Knowles

British Nuclear Fuels, plc

Risley, Warrington, Cheshire WA3 6AS

1002607 UNITED KINGDOM

\section{Internal}

1502

1708

1800

1846

1846

4511

6000

6115

6115

6119

6119

6121

6121

6300

6302

6303

6303

6305

6305

6306

6342

6342

6343

6343

6345

6345

6347

6348

6348

6348

6351

6352

6352

7141

7151

7613-2

$8523-2$
J.C. Cummings

R.E. Loehman

A.D. Romig

W.F. Hammetter

M.L.F. Phillips

D.P. Garber

D.L. Hartley

P.B. Davies

Staff (15)

F. Gelbard

Staff (7)

J.R. Tillerson

Staff (7)

D.E. E11is

L.E. Shephard

S.Y. Pickering

W.D. Weart

S.A. Goldstein

A.R. Lappin

A.L. Stevens

D.R. Anderson

Staff (20)

V. Harper-Slaboszewicz

Staff (2)

R.C. Lincoln

Staff (9)

D.R. Schafer

J.T. Holmes

M.A. Molecke (12)

Staff (4)

R.E. Thompson

S.E. Sharpton

WIPP Central Files (10)

Technical Library (5)

Technical Publications

Document Processing for DOE/OSTI (10)

Central Technical Files 

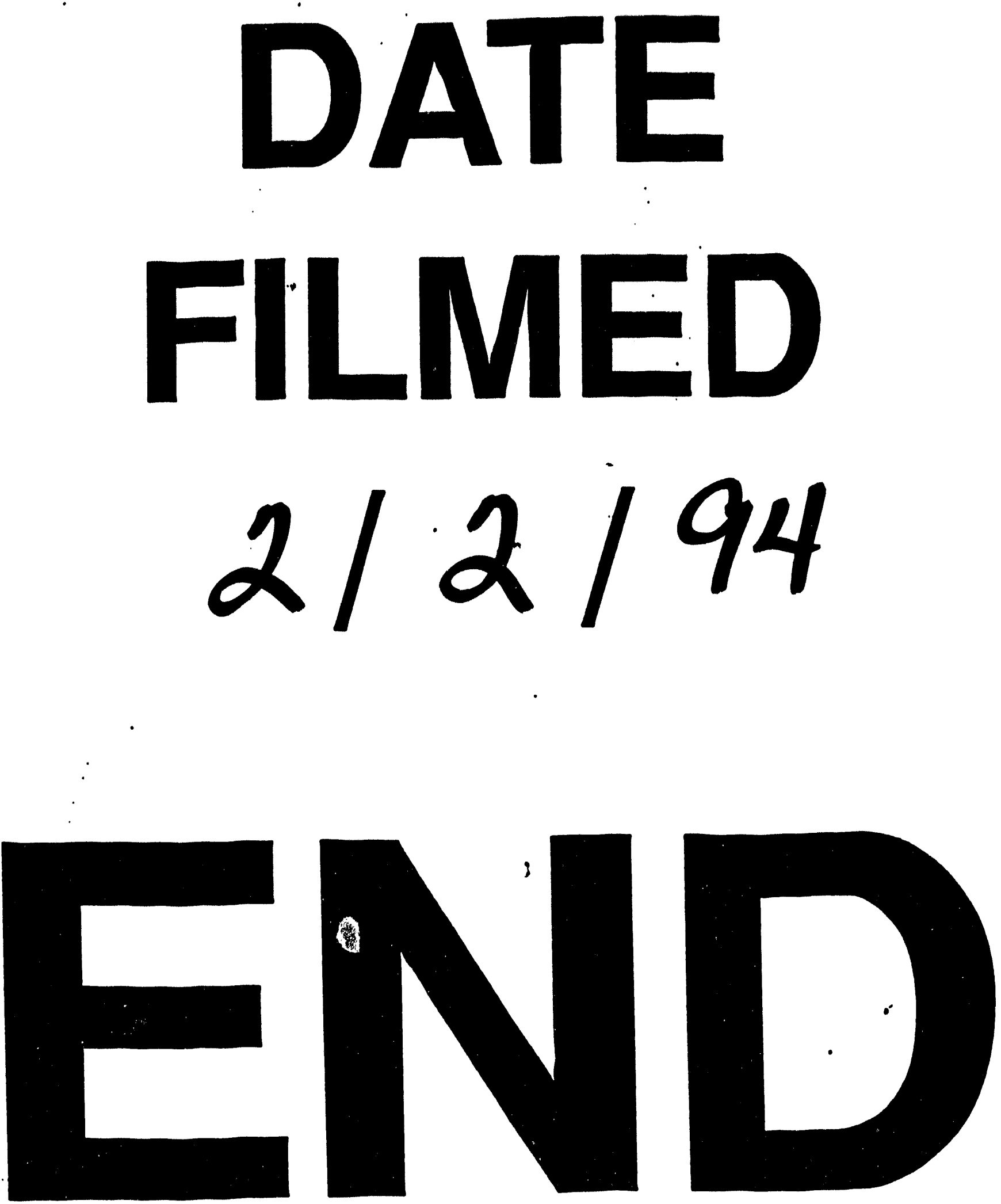
